\title{
The letters of French and German soldiers in World War One
}

\author{
Rebekka Sippel
}

A thesis submitted in fulfilment of the requirements for the degree of Master of Arts in History 


\section{Contents}

$\begin{array}{lc} & \text { Page } \\ \text { Abstract } & \text { ii } \\ \text { Acknowledgments } & \text { ii } \\ \text { Introduction } & \mathbf{1} \\ \text { Chapter 1: Mobilizing Masculinity } & \mathbf{1 2} \\ \quad \text { Mobilizing Masculinity in Germany } & 12 \\ \quad \text { Mobilizing Masculinity in France } & 26 \\ \text { Conclusion } & 36\end{array}$

$\begin{array}{ll}\text { Chapter 2: Fraternity and the Military } & 37\end{array}$

$\begin{array}{ll}\text { French Soldiers on Fraternity } & 37\end{array}$

German Soldiers on Fraternity 45

Conclusion $\quad 54$

Chapter 3: Protection of Women 55

French Soldiers on Protection of Women 56

German Soldiers on Protection of Women $\quad 67$

$\begin{array}{ll}\text { Conclusion } & 77\end{array}$

$\begin{array}{ll}\text { Conclusion } & 78\end{array}$

$\begin{array}{lr}\text { Illustrations } & \mathbf{8 3}\end{array}$

Figure1: 'L' Insomnie du Kaiser' $\quad 83$

Figure 2: 'Aux armes, cyclons! Formez vos bataillons!' 84

Figure 3: 'Allons, enfants de la patrie. Le font de gloire est ouvre!' 85

Figure 4: ‘Seddución’ 86

$\begin{array}{ll}\text { Bibliography } & 87\end{array}$

$\begin{array}{ll}\text { Primary Sources: Books } & 87\end{array}$

Primary Sources: Databases and Websites $\quad 88$

Secondary Sources: Books $\quad 89$

Secondary Sources: Articles 93

Secondary Sources: Databases and Websites 95 


\section{Abstract}

This thesis uses letters written by French and German soldiers to investigate the mobilization of masculinity during World War One 1914-1918.

Through the letters of French and German soldiers of World War One, the thesis discusses the initial ways the soldiers were encouraged to enlist, which includes discussions on patriotism. The work also discusses the concepts of brotherhood and equality, and the idea of protecting women. While masculinity in these two societies was highly militarized, the soldiers took their role as domesticated men very serious and rarely followed instructions from censors as to what to write to their families. Although soldiers were separated from their loved ones and relationships were truly strained by separation, they never forgot their role at home.

A comparative framework has been employed to highlight significant differences in French and German ideals of masculinity. This includes an emphasis on religion among French soldiers and the concept of Heldentod in German letters.

The analysis of hundreds of letters in published or digitized collections complicates the image of French and German soldiers portrayed in both official propaganda and historians' work. For example, French and German soldiers had different ideas concerning thoughts on the enemy and equality within the army took on different forms as well. Yet the soldiers from both nations had similar notions regarding goals of personal survival and the defence of the country.

Studies of World War One soldiers' letters have overwhelmingly focused on English language sources. Therefore, an overall aim of this thesis is to contribute to existing research in the English language by using French and German sources. The aim of translating these letters is to facilitate the availability of foreign language sources for English-language historians. 


\section{Acknowledgments}

First and foremost I wish to thank my supervisor, Kate Hunter, for all the support she has given me throughout the course of this research. I have been very fortunate to have had a supervisor who gave me the freedom to explore on my own, and at the same time offer guidance.

I would like to thank my partner Sobore for his support and being patient with me throughout the year. I am thankful that you have looked after our beautiful daughter Leyla so well during this time and have allowed me to focus on my work when needed.

I would also like to express my gratitude to my co-worker and friend Alex who helped me with the technical details of my work. Your encouragement and efforts to keep me on track has greatly contributed to the completion of this work.

Finally, I would like to thank my family without whose love and support this thesis would not have been completed. You have been a constant source of strength and understanding which has helped me stay positive throughout the more challenging aspects of this research. 


\section{The relationship between German and French soldiers' letters in the Great War and expressions of wartime masculinity}

\section{Focus}

The European summer of 1914 marked the beginning of World War One. While the men of Germany and France had been exposed to propaganda that encouraged them to love their respective countries for centuries, enthusiasm for patriotism reached a peak at the outbreak of the war. Through social construction, the soldier was already depicted as the new ideal man, officially forcing the domesticated and intellectual man into the background. The German and French nations developed specific variants of this patriotic ideal within the framework of propaganda, serving to encourage enlistments. German historian Andrew Donson argues: 'whereas French books claimed the war was necessary to defend the rights of man, destroy German militarism, and maintain peace, German books claimed the war was justified by France's and Great Britain's refusal to recognize Germany's rights to be a world power.'

Making patriotism more potent was the idealization of military masculinity in these two societies. Hatred for the enemy was a key element in persuading young men to enlist, especially when morale was low after particularly heavy losses. War propaganda encouraged strenuous masculinity and encouraged boys to embrace militarist violence and extreme nationalism.

While the focus of my research concerns masculinity during wartime, I have decided to focus on three specific concepts of masculinity in three chapters: mobilizing masculinity, fraternity and protecting women. Through the analysis of a sample of letters that German and French soldiers sent home to their families, this research will show that while a number of soldiers lived up to the expectations of the perfect soldier, others merged their wartime and peacetime identities, and in fact, rejected the public image of masculinity. Letters aimed to catalogue and make sense of the terrifying experiences of the soldiers, and served as acts of remembrance. Indispensable to gaining an understanding of the

${ }^{1}$ Andrew Donson, Youth in the Fatherless land- war pedagogy, nationalism, and authority in Germany 1914-1918, Harvard University Press: Cambridge, Massachusetts and London, 2010, p. 19. 
soldiers' war culture and how the soldiers were shaped by the war, letters reveal the sometimes conflicting emotions of the soldiers, speaking of the extraordinary pressures that total war imposed on the soldiers and their value systems. Bernd Ulrich and Benjamin Zieman rightfully state that: 'The value of this multi-vocal presentation of the soldiers' point of view is that it enables us to avoid stereotyping soldiers as stoical idealists to a man.'2 Indeed, after reading a variety of letters, the wide ranging set of perceptions and observations from the men became obvious. The conflicting interpretations of the frontline-experience expose the social pressures men were exposed to in war and how some men developed coping-strategies to deal with the realities of war, whereas others abandoned the stoical manliness promoted at the time and openly discussed the horrors of war and fear.

While past work has focused on higher commanders of the war, the letters of this thesis represent the views and emotions of the common soldier. It should come as no surprise that directly after the war, only officers had the opportunity to publicise their thoughts on the war: 'Naturally the higher commanders wrote to state their cases not only in official reports, but also in memoirs. Officers who had extraordinary careers, been much decorated, or who had a tale publishers considered interesting wrote in the first decade after the war.' ${ }^{3}$ Officers were much more likely to be rewarded and celebrated for their efforts, or condemned for failure, as they led battles and were in charge of developing military strategies among other things. It was only these stories which were considered worth reading and studying.

Yet, even after the initial decades after the war, this focus on the 'main men' of the war had not changed. ${ }^{4}$ Martha Hanna explains that perhaps historians have attempted to stay away from the stories of the everyday soldier due to the issue of literacy, and there is this myth that the everyday soldiers struggled to write down his experiences. Yet Hanna rightfully claims that they did in fact, especially

2 Bernd Ulrich and Benjamin Zieman, German Soldiers in the Great War - Letters and Eyewitness Accounts, Christine Brocks (trans.), Pen and Sword Military: South Yorkshire, 2010, p. ix.

${ }^{3}$ Alexander Watson, Enduring the Great War - Combat, Morale and Collapse in the German and British Armies 1914-1918, Cambridge University Press: Cambridge, 2008, pp. xvii-xviii.

${ }^{4}$ Martha Hanna , 'A Republic of Letters: The Epistolary Tradition in France during World War I', The American Historical Review, Vol. 108, No. 5, December 2003, p. 1343. 
referring to the general French population, have a great skill and a literate command: 'The elementary school curriculum of the early Third Republic gave considerable time to learning the rules, protocols, and cultural significance of family correspondence $[\ldots]$ the letters of distinguished writers were used both to test children's command of spelling, punctuation, and grammar and to serve as models to be emulated.' ${ }^{5}$ Even if the literary skill of the common soldier was not as advanced as that of the officers, their letters nevertheless are important - they are still authentic.

It has been acknowledged that history must turn to the condition of the everyday soldier in order to explore social aspects of the war. As Iggers explains: 'The newer histories indeed challenged the traditional historiography, which had concentrated on political and social elites, and demanded the inclusion of those segments of the population that had long been neglected. ${ }^{6}$ This thesis greatly contributes to this shift in historiography.

\section{Methodology}

Around 28 billion letters circulated during the war. ${ }^{7}$ Due to the large number of soldiers' letters, it was very important to this research to build arguments based on an appropriate sample of letters. Edward G. Lengel explains: 'Only recently have historians come to fathom the sheer volume of letters and diaries still remaining from that period, most of which never made their way into print. If unpublished accounts of the war have yet to be studied in their full extent, however, so too have published accounts fallen by the wayside. ${ }^{8}$ Lengel goes on to argue that on the few occasions that letters have been used for research, a very selective few letters had been used to make huge generalisations. ${ }^{9}$

Alternatively, I have come across the other extreme throughout the course of my research. Alexander Watson argues that as over 20 million men passed

\footnotetext{
${ }^{5}$ Hanna, 2003, p. 1343.

${ }^{6}$ Georg G. Iggers, Historiography in the twentieth century-from Scientific Objectivity to the Postmodern Challenge, Wesleyan University Press: Middletown, 1997, p. 7.

${ }^{7}$ Ulrich and Zieman, p. ix.

8 Edward G. Lengel, World War One Memories - an annotated bibliography of Personal Accounts Published in English since 1919, The Scarecrow Press ink: Lanham Maryland, 2004, p. xiii.

${ }^{9}$ Lengel, p. xiii.
} 
through German and British armies alone, a collection of 100 letters would hardly be sufficient to make generalisations. ${ }^{10}$ While he attempted to focus on using a huge variety of letters in his book Enduring the Great War-Combat, Morale and Collapse in the German and British Armies 1914-1918 he may have thought too much about how believable an argument based on letters really is. With this in mind, he actually starts to use other primary sources to build up an argument, not letters. The fact that letters are important primary sources seems to disappear completely under the mountain of official propaganda, diary entries, memoirs and official contemporary data. Just as well, we would need to argue that there were millions of contemporary newspaper articles, propaganda material and official data entries from the militaries; yet historians still make generalisations and important claims based on a relatively small selection of such material. Letters should not be treated any differently.

I called on hundreds of letters from French and German soldiers found in published and edited work, translated by others and myself, to make sure my arguments are built on not just one soldier's beliefs and reflect on the wider soldier population's views. I have occasionally made use of other primary sources, such as French newspaper articles from Le Matin and Petit Parisien, propaganda posters, contemporary diary entries or references to German war literature to further support my findings, but they are not placed in the foreground and really aim to only supply more context for the letters.

Each of the three chapters will have a section for discussions on French and German soldiers' letters on the different concepts of masculinity. ${ }^{11}$ Watson's work encouraged me to distinctively separate French and German letters throughout the thesis by having them separated in each chapter. Watson's work is a comparative study, but having the work broken down by topics rather than by

\footnotetext{
${ }^{10}$ Watson, p. 8.

${ }^{11}$ I have consciously divided each chapter into two parts, one for each country, as I have found previous comparative studies particularly confusing when the chapters have been merged into one. When looking at Alexander Watson's Enduring the Great War, for example, it is easy to lose sight of the main comparative approach, and one struggles to distinguish clearly which attributes are distinctive to one country - discussions on why men fought, self-deception and survival attitudes, as well as discussions on junior leadership are all very important concepts captured in Watson's book; it is just challenging at times to grasp national characteristics.
} 
country, meant that a lot of data and important differences between country's were lost within the chapters.

Considering what units of comparison are most appropriate, looking at German and French soldiers seemed highly appropriate. My German heritage and knowledge of the language strongly encouraged me to use German soldiers' letters. Additionally, Robin Higham and Dennis E. Showalter explain that Germany in particular poses a great element for a comparative approach:

The central challenges for historians of Germany in the First World War, as perhaps for students of all the major belligerents, are those of synthesis and comparison. The German literature on the war, outstanding in many ways, is notably more specialized and fragmented than that of, say, Great Britain, a reflection in part of the gaps that exist in the German archives (especially the military ones) and also of diverging national historiographical traditions... A general plea must also be made on behalf of comparative history, the universal solvent for all myths of national exceptionalism - in which German history has always been fertile - and the only way to be sure which elements of a nation's experience are indeed unique. ${ }^{12}$

Due to the long-lasting difficulties between Germany and France, France became an obvious and interesting second component for this thesis. Their similar war experiences in terms of experiencing occupation, heavy casualties, and economic struggles formed a strong link between the two nations, while it also allowed me to cross the boundaries of the war front by looking at both sides of the front.

Using a comparative approach, the research aims to highlight how different soldiers of the two countries dealt with the strongly promoted image of "the ideal soldier". While keeping in mind the construction of national differences, I will also take the similarities of the German and French soldiers into consideration as the world of trenches had national variants but at the same time managed to explore the universality of the masculine warrior. Nancy L. Green explains that 'Comparisons can serve to highlight that which joins human experience while

\footnotetext{
${ }^{12}$ Robin Higham and Dennis E. Showalter (eds.), Researching World War 1 - A Handbook, Greenwood Press: Westport, Connecticut and London, 2003, p. 33.
} 
exploring that which remains specific to individuals or groups.' 13 Some comparative studies only focus on differences, while others focus on the similarities; this research follows a more ambitious approach by doing both.

This thesis highlights the internationality of the Great War. The major way in which I have done so is by focusing on the German and French war experience. English-language research on the war rests on a very narrow documentary base and overwhelmingly ignores the multi-lingual nature of the war. As Higham and Showalter suggest, this stems from a certain laziness of the English-speaking writers who are not prepared to cross the language barriers: 'English-speaking writers have generally preferred to focus on Britain and her own heroic contributions - even the epic of Verdun has been eclipsed, in Anglo-America, by the horrors and heroism of the Somme and Passchendaele. ${ }^{14}$ However, the issue is also that non-English historians started to focus on World War One history relatively late. French historians came to study the Frist World War relatively late compared to those historians of other countries, which Jay Winter and Antoine Prost attribute to the 'tyranny of the archives on academic history'. ${ }^{15}$ 'The opening of military archives did not produce much in this regard; military reports on soldiers' morale were not particularly illuminating.' 16

This strong traditional focus on English sources has proven to be a major obstacle to the historical understanding of the war. Winter and Prost go on to explain that particularly the French war experience has been neglected in this field: 'France was both the supreme victor and victim of the Great War, and France's contribution, the "price of glory", has never been adequately understood or acknowledged in the Anglo-Saxon world.' ${ }^{17}$ Quite critical of English-speaking historians, they explore the reasons for the neglect of the French war experience: 'The relative neglect of the French experience is easily explainable. In addition to language, there are numerous barriers that separate the French from the English-

13 Nancy L. Green, 'Forms of Comparison', in Deborah Cohen, and Maura O'Connor (eds.), Comparison and history: Europe in cross-national perspective, New York: Routledge, 2004, p. 45.

${ }^{14}$ Higham and Showalter, p. 51.

15 Jay Winter and Antoine Prost, The Great War in History - Debates and Controversies, 1914 to the Present, Cambridge University Press: Cambridge, 2005, p. 97.

${ }^{16}$ Ibid., p. 98.

${ }^{17}$ Ibid. 
speaking world... Perhaps most important however, in the failure to acknowledge the French achievement, has been the historiography of the Great War itself.' ${ }^{18}$ It appears that the English-speaking world has not yet been prepared to fully explore the achievements and potential of the French soldiers.

This thesis will show that it is possible to conduct thorough research of foreign language sources within the English-language framework and that it is possible to explore the glory of other nations during wartime. Indeed there has been a general turn towards linguistics in historical study, and it seems to be well-recognised that we need to europeanize the discussions of the war, so as to affirm the global sense of the war, but it is rarely practiced. Winter and Prost attribute this issue to the fact that 'In most respects, the war has been constructed in discrete national terms. The first rule that seems to govern this historiography is that every nation has its own Great War.' ${ }^{19}$ Nicolas Beaupre convincingly argues, however, that 'Gaps, silences, the absences of a phenomenon in a specific culture, are thus only revealed by the presence of the phenomenon in another country. ${ }^{20}$

\section{Chapter Outline}

The focus on three aspects of masculinity will allow me to discuss the relationship the soldiers had with the state and discuss whether soldiers could live up to the manly and heroic actions that were promoted at the time. The boundaries of the home and fighting front will also be highlighted as most historians still seemed locked in the assumption that there was an antithetical relationship between the home and front, without acknowledging that the correspondence brought these separated spheres into a relationship. ${ }^{21}$ Leonard V. Smith supports this view: "we need to put the separation between soldiers and civilians in its proper perspective and above all not to exaggerate it. ${ }^{, 22}$

\footnotetext{
${ }^{18}$ Winter and Prost, p. 98.

${ }^{19}$ Ibid., p. 192.

20 Nicolas Beaupre, 'New Writers, New Literary Genres 1914-1918: The contribution of Historical Comparatism (France, Germany)', in Pierre Purseigle (ed.), Warfare and BelligerencePerspectives in First World War Studies, Brill: Leiden and Boston, 2005, p. 324.

${ }^{21}$ Michael Roper, 'Maternal relations: moral manliness and emotional survival in letters home during the First World War', in Stefan Dudink, Karen Hagemann and John Tosh (eds.), Masculinities in Politics and War - gendering modern history, Manchester University Press: Manchester and New York, 2004, p. 297.

${ }^{22}$ Leonard V. Smith, The embattled self-French Soldiers' Testimony of the Great War, Cornell University Press: Ithaca and London, 2007, p. 105.
} 


\section{Chapter One: Mobilizing Masculinity}

The first chapter, with a focus on the concept of mobilizing masculinity, includes discussions on expressions of patriotism, religious feelings and attitudes towards the enemy-it explores how men were motivated to fight. The chapter looks at the idea of soldiers being willing to die for their countries, and whether this patriotism and love for their country was really the driving force behind enlistments. Some soldiers definitely were prepared to die to protect their country, while others were more eager to protect their families, and others were mainly encouraged by Christianity and the idea of doing God's work. Religion was perhaps a way for soldiers to seek relief in times of death and killing. While some simply could not seek relief in the language of the Bible, others saw this as a way to accommodate death. The very German-orientated concept of Heldentod [to die a hero's death] truly reflects on how deeply patriotic fever was embedded in the German men's mind and encouraged bravery at the front.

Letters from the French soldiers Pierre Teilhard de Chardin, Etienne Derville, Hendrik de Man, and Henri Fauconnier, in combination with contemporary diary entries from Felix Klein and discussions on religion in France in Annette Becker's War and Faith - The Religious Imagination in France, 1914 - 1930 will demonstrate that French soldiers were encouraged to think of the enemy as beasts. Yet the soldiers had, from the beginning of the war, been very critical of the war effort and reflected on what the war was costing them. These sources show that religion played an important role in sustaining religious men during the war and men who turned to religion during the war, even when they were previously not religious, tended to do so out of superstition and only superficially believed in God. The role of religion is much more apparent in French soldiers' letters compared to German soldiers' letters.

The letters of German soldiers shed light on discussions on the brutality of German soldiers. While it has been suggested that the war was aggressive on the Germans' part, this was not so dominantly the case for the soldiers. ${ }^{23}$ Andrew Donson argues that 'It was the outbreak of the war, not prewar imperialism, that

23 Gregor Schoellgen, Escape into War? The Foreign Policy of Imperial Germany, Berg Publishers Limited: Oxford, 1990, p. 4. 
exposed youths widely to a militarism and nationalism that exalted war and expected citizens to die for the sake of Germany's territorial expansion and status as a great power. ${ }^{24} \mathrm{He}$ supports this view by stating that 'Teachers had their pupils read soldiers' letters in class because this activity supposedly mediated the "thrill" of war.'25

The thesis will discuss Donson's analysis of Ernst Juenger war stories, as well as David Welch's book Germany, Propaganda and Total War 1914-1918, in combination to soldier letters found in Bechmann and Mestrup's collection of letters, to discuss how soldiers' hardened attitude to warfare encouraged them to fight bravely and think of the enemy as inhumane. In contrast, a different sample of letters found in Bechmann and Mestrup's collection will reflect on the truly unpatriotic fever of German soldiers. While it is true that the German education and literature intensified and glorified military violence of soldiers and thus encouraged young recruits to pursue such military violence also, it seemed to have the opposite effect on some recruits who condemned brutality openly.

\section{Chapter Two: Fraternity and the Military}

The second chapter on brotherhood highlights class ranking within the structure of the armies, and whether soldiers knew their place and followed orders from their commanders. Some soldiers built essential friendships at the front and were deeply affected by the death of a friend, while others felt relatively alone based on their background and found it hard to form permanent bonds with fellow soldiers. While fraternity was a major ideal of wartime masculinity, it must be recognised that not all soldiers became friends immediately simply based on the fact that they were fighting on the same front in the war. Universal conscription meant that there were high levels of dissatisfaction in the German and French armies.

Soldiers' letters reveal that comradeship was not automatic and soldiers defied army hierarchies by not following orders. This included discussions on censorship. Unlike what has been argued in the past, soldiers had very little respect for censors and openly expressed so in their letters, particularly the

\footnotetext{
24 Donson, p. 5.

${ }^{25}$ Ibid., p. 69.
} 
French soldiers. Additionally, soldiers condemned many of the actions of their commanders and if many soldiers lost their lives in the battlefield, they convicted their commanders of incapability.

Discussions on French soldiers' comradeship in France and the Great War 1914-1918 - new approaches to European history, as well as various chapters in Leonard V. Smith's The embattled self-French Soldier's Testimony of the Great War, will be called into question by letters from Pierre Teilhard de Chardin found in Rene Hague's The Making of a mind - letters from a soldier-priest 1914-1919 and Fernand Maret who contributes greatly to the argument that class tensions were by no means suspended within the French army. Yet soldiers managed to overcome certain barriers by focusing on a small group identity within their ranks. The idea of a noble death managed to deem young men as equals to older men as everyone faced this possibility and allowed French soldiers to overcome certain barriers within the French army.

Letters from soldiers such as Paul Liss, Johannes Winzer and Ernst Bischoff found in Bechmann and Mestrup's collection, as well as Birthe Kundu's and Thomas Kuehne's article in Hagemann and Schueller-Scpringorum's book Home/Front: The Military, War and Gender in twentieth Century Germany will reflect on the popular idea of a strict German military hierarchy. However, soldiers partly managed to overcome this barrier by a strong bond of fraternity, which specifically encouraged personal sacrifice for others - rescuing each other was the focus of comradeship in Germany and soldiers were to honour each other; especially in death by decorating dead soldiers' gravesides.

\section{Chapter Three: Protection of Women}

The third chapter on the idea of protecting women focuses on the meanings and understandings of gender during the war and highlights the key roles of women working at home to produce food and raising children. The thesis argues that the idea of protecting women took on a variety of meanings. The letters raise discussions on whether soldiers wrote about their physical wounds to women, whether they consciously chose to not write about certain aspects of the war experience to protect women from worrying at home, or whether men opened up to women the same way they opened up to men in their letters. I will be able to 
explore the ways men protected their women at home by using humour to disguise the seriousness of their experiences and by choosing to discuss everyday life at home more often than their warfront life.

Marcelin Cailleau's letters, as well as letters from Pierre Tiesserant and an extensive sample from Paul Pireaud's letters to his wife found in Martha Hanna's, Your Death Would Be Mine; Paul and Marie Pireaud in the Great War, in combination with historians' entries in Jennifer D.Keene's and Michael S. Neiberg's Finding Common Ground - New Directions in First World War Studies demonstrate that French women were not meant to know about the brutalities of war. Instead of descriptive letters of war wounds and corpses, soldiers used humour and a focus on their role as a family man to drive away from this brutality.

Letter entries from German soldiers similarly attempted to reassure their family members at home that they were safe and had enough food and shelter, yet they frequently referred to descriptions of countrysides and hopes of reunions as well. These were different techniques to those employed by French soldiers. Letters from Rittmeister Hanns, Otto Lepiner, Walter Hagen and Karl Probst are some sources I consulted to support this argument. However, the soldiers Rudolf Theis, Gerhard Theodor Bernhard Goepel and Wilhelm Ernst in their letters show that the German soldier was more prone to describe brutalities of war and take on a hardened role as a family man, which meant that some German soldiers wrote unaffectionate letters on topics of fatherhood. 


\section{Chapter One: Mobilizing Masculinity}

This chapter will discuss the mobilization of masculinity of the First World War and specifically explores how men were encouraged to fight. This includes discussions on patriotism, thoughts of the enemy, attitudes towards death and views on the identity as warriors. The idea of death connects specifically to the concept of patriotism. The love of country, in combination with the reward of glorification and dying in the service of the country, encouraged men to enlist. As this chapter on patriotism will explore, masculinity in both France and Germany marked a highly militarized image, with a clear move away from the domesticated man. 'With the rise of the modern nation state came the assumption that citizens had both the right and responsibility to serve the nation militarily. ${ }^{26}$ There was a need to clear oneself of any suspicions of cowardice and assert honour and commitment to the war.

Particularly in regards to attitudes towards death, it was very important that the masculine concepts at the time promoted no vulnerability and no fear of dying, as this was a very real possibility for all soldiers. Soldiers were to face this reality bravely and freely. Death on the battlefield was nothing new; both nations had experienced extreme warfare in their respective nations' history. The scale of death that they encountered from 1914, however, was very new. Consequently, '[i]n and out of the trenches, a massive need arose to understand and master death, and a need to articulate solutions to its existential perils. ${ }^{27}$

\section{Mobilizing Masculinity in Germany}

The German people were exposed to ideas of extreme patriotism and military manhood in the time leading up to the war. As Karen Hageman explains: 'Industrialized mass warfare demanded an unprecedented degree of patriotic national mobilization among both soldiers and civilians. ${ }^{28}$ Although the German military already had enormous prestige before 1914, the features of the ideal

\footnotetext{
${ }^{26}$ Jennifer D, and Michael S. Neiberg (eds.) Finding Common Ground - New Directions in First World War Studies, Leiden and Boston: Koninklijke Brill NV, 2011, p. 88.

${ }^{27}$ Leonard V. Smith, The embattled self-French Soldier's Testimony of the Great War, Cornell University Press: Ithaca and London, 2007, p. 63.

${ }^{28}$ Karen Hageman, 'The military, Violence, and Gender Relations in the Age of the World Wars', in Karen Hageman and Stefanie Schueller-Springorum (eds.), Home/Front: The Military, War and Gender in twentieth Century Germany, Berg Publishers: Oxford and New York, 2002, p. 7
} 
aristocratic male officer were dramatically altered. Hageman explains this in more detail:

...the aristocratic concept of the officer that had dominated representations of the officer corps after 1871 was increasingly stigmatized as "effeminate". The general staff involved in planning the next war, in particular, favoured an image of the officer and of masculinity characterized by "cool professionalism", which drew its claims to exclusivity from an understanding of military leadership as an esoteric science based on expert knowledge. ${ }^{29}$

There was an intense hardening and masculinization of the model officer to fit into the new period of war. Men were expected to master contemporary warfare by becoming more focused on showing physical strength rather than a calm, professional side. Andrew Donson agrees: 'Strenuous masculinity - the ideal of toughness, risk-taking, soldiering, action, and youthful vigour - was a limited model of manhood before 1914, when the prevailing view was that manliness involved emotional self-control, years of wisdom, and the calming demeanour necessary to support a family.'30

Men were encouraged to grow as a person and a soldier. While everybody was supposed to join the war effort, it was particularly the young men and future soldiers of Germany who had to display their commitment to war. The initial way to show this commitment was through enlistment. Having enough volunteers was unproblematic for the German military, as 'The militarization of German society through a system of prewar universal conscription successfully created the shared notion that rooted male gender identity in serving the nation honourably during time of war.' ${ }^{31}$ Yet, Alexander Watson advises that 'In Germany, the peacetime conscript army of 808,280 soldiers quadrupled in twelve days to a force of 3,502,700 strong. Additionally, 250,000 men volunteered during August 1914; not as many as the propaganda claimed but nonetheless an extremely impressive figure for a country which had already conscripted 36.5 per cent of its military-

\footnotetext{
${ }^{29}$ Hageman, p. 7.

${ }^{30}$ Andrew Donson, Youth in the fatherless land - war pedagogy, nationalism, and authority in Germany, 1914 - 1918, Harvard University Press: Cambridge, Massachusetts and London, 2010, p. 229.

${ }^{31}$ Keane and Neiberg, p. xiii.
} 
aged manpower.' ${ }^{32}$ Men grew up with the impression that they had to become military men when it was required of them in order to defend the nation. This ideal was taken very seriously by the young men as Lynn Abrams and Elizabeth Harvey point out: 'In contrast to earlier mercenaries, they committed their entire person, their strength and emotions, engaging and identifying completely with the national cause and often went to the front as mere boys. ${ }^{33}$ This enthusiasm to join the war effort is evident in many letters written at the beginning of the war. Consider, for example Hans Bucky's letter at the beginning of the war to his parents, in which he stated: 'But now to the actual reason of my writing: I want to join them in the battlefield [...] all my colleagues, be it from school, or be it from business, are leaving everything behind to follow the call of the Kaiser. Do you want your son to be an exception to this? ${ }^{34}$ Bucky was particularly frustrated throughout his entire letter that his parents did not support his wish to join the war effort.

Perhaps this enthusiasm to join the war effort can partly be explained by the youth literature young men were exposed to on a regular basis. Youth literature spoke of hyper-masculinized German soldiers that joined the war effort freely and happily, killing an unrealistic number of enemy soldiers. Young men were encouraged to read this kind of literature at home, but also, even more so, at school. It was designed to get students interested in weapons and destruction, as well as developing a very specific masculine war identity. War stories by Ernst Juenger were very popular, as well as the stories of other writers: 'When a fictional male youth arrived on the front, he became a monolithic, machine-like German soldier. He was loyal and fierce, and he lacked all personality., ${ }^{35}$ Donson continues to explain just how these kinds of stories managed to move away from the realities of war in the minds of these men: "ideas of a "holy" war combined

32 Alexander Watson, Enduring the Great War-Combat, Morale and Collapse in the German and British Armies 1914-1918, Cambridge University Press: Cambridge, 2008, p. 45.

${ }^{33}$ Lynn Abrams and Elizabeth Harvey (eds.), Gender Relations in German History - power, agency and experience from the $16^{\text {th }}$ to the $20^{\text {th }}$ century, UCL Press: London, 1996, p. 136.

${ }^{34}$ Hans Bucky to his parents, beginning of war, exact date unknown, in Denis Bechmann und Heinz Mestrup, Quellen zur Geschichte Thüringens - Wann wird das Morden ein Ende nehmen? Feldpostbriefe und Tagebucheinträge zum Ersten Weltkrieg, Landeszentrale für politische Bildung Thüringen: Erfurt, 2008, p. 60. 'Doch nun zum eigentlichen Grund meines Schreibens: Ich möchte mit hinaus ins Feld [...] Sämtliche meiner Kollegen, sei es von der Schule, sei es vom Geschäft, lassen alles stehen und liegen und folgen dem Rufe unseres Kaisers. Wollt Ihr, daß Euer Sohn eine Ausnahme macht?'

${ }^{35}$ Donson, p. 99. 
with the notions of martyrdom to justify the brutality and fearlessness of soldiers. Youth war literature portrayed an exciting war of movement and a home front of celebrations and national harmony - a gross distortion of the ugly war of attrition that increasingly divided the populace. ${ }^{36}$ The idea of a just war was deeply infused into the everyday life and sentiments of the pupils. Such youth literature was studied at school but was also published for the general population to read during the war. It is interesting to note that although young French men were also exposed to war youth literature, war pedagogy in Germany was more jingoist than in France-while French schoolchildren also read war stories and letters, their focus was on German atrocities, maintaining World Peace and bringing republican values to the World. France glorified the "soldier of justice" whereas Germany justified the war as necessary for world power. ${ }^{37}$

German soldiers' letters frequently explored why they so eagerly joined the war effort. One soldier, for example, wrote in August 1914: 'I can't think of anything more hateful than to be forced to sit at home doing nothing when there is war and fighting out there.'38 Another wrote: 'You must not imagine that I write this in a fit of war-fever; on the contrary, I am quite calm and am absolutely unable to share the enthusiasm with which some people here are longing to go to war [...] I know that you are a dear, good, sensible little Mother, and would not wish that your sons should show cowardice in the face of great danger and stay prudently behind. ${ }^{39}$ Yet another soldier followed a similar pattern of condemning war, but showing his love for the nation. He wrote: 'I think that war is a very, very evil thing, and I believe that even in this case it might have been averted by a more skilful diplomacy.' But he went on that now that it has been declared, the people need to come together and fight in the same war. Although he described war as inhuman and depraving, the nation has called upon the brave German men to defend the country. ${ }^{40}$

\footnotetext{
${ }^{36}$ Donson, p. 9

${ }^{37}$ Ibid., p. 90.

38 Anonymous soldier, letter of August 1 1914, in Marilyn Shevin-Coetzee and Frans Coetzee (eds.), Empires, Soldiers, and Citizens - A World War 1 Sourcebook, Wiley-Blackwell an imprint of John Wiley and Sons Ltd: United Kingdom, 2013, p. 23.

${ }^{39}$ Anonymous soldier, in Marilyn Shevin-Coetzee and Frans Coetzee (eds.), p. 23.

40 Anonymous soldier, 24 September 1914, in Philipp Witkop, German Students' War Letters, First Pine Street Books: United States of America, 2002, p. 62, pp. 17-21.
} 
Watson argues that soldiers did not really realise just how vulnerable they were at the front, which is also partially the reason why men initially enlisted in such high numbers. He discusses how soldiers became more fatalistic about the consequences of risk-taking. He argues that men willingly joined the war effort, because they did not realise that their chances of survival were very small. They were convinced of their invincibility. Watson writes: 'Arthur Meier, considering a possible transfer to the Somme battlefield in 1916, [...] fatalistically concluded, "even in this case, I trust in our omnipotent and all-loving God, who guides everything for the best." 41 It is argued that the belief in God or luck would shield from danger and provided security and reassurance.

Soldiers' letters however demonstrate that as war went on, they were very much aware of their dispensability and consistently tried to prepare their loved ones for the day of their death. Even the soldiers, who did mention good luck charms or prayers that they thought protected them, also expressed this belief that their lives could end at any moment. Watson himself refers in his book to a doctor in service in 1914: 'The risk of death and dismemberment also placed considerable strain on soldiers. One doctor serving in a pioneer company in 1914 recorded seeing some of the men, convinced that they would be killed, repeatedly writing a "last" goodbye card to relatives at every opportunity." 42 I would argue that the scenes of destruction, as well as the experience of seeing fellow soldiers die so unselectively, partially prepared soldiers for this. ${ }^{43}$

Germany had taken on a highly militarized masculinity that encouraged territorial expansion and domination. Part of this aim for world power, was the need for very capable, strong, patriotic men with military strategic ability. 'The emphasis now rested upon purely military terms like toughness, endurance, service and duty, which had much more to do with the realities of modern warfare than with the image of a caste of aristocratic warriors. ${ }^{44}$ Military men were now

\footnotetext{
${ }^{41} \mathrm{H}$ Weber to friends, 7 January 1915, DTA, 865, in Watson, p. 95.

42 Watson, p. 20.

${ }^{43}$ It is important to note that it is the soldiers own expendability which seems acceptable to soldiers. In the second chapter of this thesis, the study on brotherhood, I will highlight that it was much more difficult for soldiers to accept the expendability of their soldier friends and it was difficult to make sense of this.

${ }^{44}$ Marcus Funck, 'Ready for War? Conceptions of Military Manliness in the Prusso-German Officer Corps before the First World War', in Hageman and Schueller-Springorum p. 58 (Author's italics.)
} 
the clear ideal masculine representation, evidently pushing the aristocratic men as the ideal masculine representation aside. Men who did not enter the war were branded as weak, cowardly and feminine and it was up to the military men to prove their manliness on the battlefield. The specific characteristics of these military men are explored in more detail in Marcus Funck's article: 'princely loyalty and patriotism, a natural gift for leadership and willpower, discipline and sense of duty, fearlessness of death and heroic courage, composure and honourableness. Those virtues, to which the officers corps and to a growing extent the entire male society were subjugated, were held together by the idea of military manliness. ${ }^{45}$

Toughness and endurance are particularly evident in letters German soldiers wrote home. The soldier Ringer, for example, explored this concept of endurance in comparison between German and Russian soldiers specifically. While describing a particular battle in a letter home, he wrote: 'To what extent us poor fellows had to languish, nobody could imagine, but endure it we did. The Russians tried to break through with a vengeance, but to no avail; for we are Germans and don't back down. ${ }^{46}$ He highlighted the belief that no matter what German soldiers have to face, they will not give up and persevere over the enemy. Rudolf Malsh stated the following in his letter: 'Will our People endure the economic and emotional pressure long enough? Hindenburg was truly right: those with the strongest nerves will win. ${ }^{97}$ Perhaps a little more taken back in his selfreflection, Malsh does not specifically say that Germany will have the strength to endure the war experience for longer, but he certainly implied it.

One reason perhaps, why the German soldiers were inspired to endure warfare, was the fact that dying for the fatherland was largely celebrated and soldiers were always reminded that even if they did not make it home from the battlefield, their actions would be recognised. The portrayal of death was very

\footnotetext{
${ }^{45}$ Funck, p. 43.

${ }^{46}$ Ringer, to „Trudchen“, 27 October 1914, in Bechmann and Mestrup, p. 76. 'Was wir armen Kerle da haben schmachten müssen, stellt sich keiner vor, aber ausgehalten haben wir. Die Russen versuchten in starker Macht durchzubrechen, aber vergebens, wir sind doch Deutsche und gehen nicht zurück.'

47 Dr. Rudolf Malsch from Lomza to Professor Alexander Cartellieri, 1 February 1918, in Bechmann and Mestrup. p. 232. 'Wird unser Volk den wirtschaftlichen und seelischen Druck lange genug aushalten? Hindenburg hatte wirklich recht: Gewinnen wird, wer die stärksten Nerven haben wird.'
} 
positive and referred to as Heldentod. In regards to this aspect of patriotism and manliness we are, again, able to look at youth literature and how this represented death. Stories of Theodor Koerner, for example, were very popular and widely circulated. Koerner, despite having a great career ahead of him and being engaged, left all his commitments behind and went to war against France in March 1813. "Not only were memories of Koerner and other "German heroes" kept alive above all in times of heightened militarism and nationalism [...] but also his image was transformed over the course of the nineteenth century from a "valorous" and "freedom-loving" "son of the middle class" with Germannational views to a soldierly hero. ${ }^{48}$ In the stories, every soldier's death was peaceful and glorious - soldiers never died in anguish. This war literature justified determination and courage. ${ }^{49}$ Heroes like these were the manliest of men and served to inspire the common soldier. They defined the norms of masculinity and created this myth of death for the fatherland.

While Karen Hagemann explains that this myth was neither new nor specifically German, I would argue that it nevertheless stands out when looking at German soldiers' letters compared to those letters of French soldiers. ${ }^{50}$ Donson builds on this argument by stating that 'The highest masculine ideal was to not be afraid of "dying on the altar of the Fatherland". ${ }^{51}$ The fact that soldiers were not supposed to be scared of dying, goes hand in hand with the fact that if they were to die, this would be a glorious act, which soldiers were supposed to embrace.

It is extraordinary to see how soldiers support this concept of Heldentod in their writings home. Soldiers appeared to accept their expendability and discussed how they are making their sacrifice freely, out of free will. Heinrich F. Simon discussed how he waited for the day he would die in battle: 'Calmly and matterof-factly I am awaiting my destiny, which will sooner or later catch up with me,

\footnotetext{
${ }^{48}$ Karen Hageman, 'German heroes: the cult of the death for the fatherland in nineteenth century Germany', , in Stefan Dudink, Karen Hageman and John Tosh, (eds), Masculinities in Politics and War - gendering modern history, Manchester University Press: Manchester and New York, 2004, p. 116

${ }^{49}$ Donson, p. 100.

${ }^{50}$ Hageman, 2004, p. 117.

${ }^{51}$ Donson, p. 230.
} 
yet I know that our sacrifices will not be in vain. ${ }^{52}$ Writing to his former teacher in April 1915, Ernst Bisschoff described his attitude towards a potential death in similar positive terms: 'The thought of death comes to my mind, the life of the past flashes by at lightning speed. This awakens a new will to live. "We have to go back! There is a race against death. He who dares wins!"'53 Walter Hagen mentioned the fact that some of his fellow young men met their death on the battlefield, but defended these tragedies by stating that although they died in the prime of their youth, 'They knew what was in store for them, when they joyfully and in high spirits went out to the battlefield. ${ }^{54}$

The German military believed in the relationship between masculinity and violence. Soldiers' ideal of martial masculinity was an inclination towards violence and killing. Qualities like aggression and physical courage were defined as being essential for both masculinity and war and as a result, were expected of all soldiers. Sabine Kienitz explains that:

The war was to toughen up and regenerate a manhood described as effeminate, insecure and nervous; it would recover under the healthy influence of fresh air and male camaraderie. The frequently used metaphor of the war as a "steel bath" (Stahlbad) connoted its therapeutic effect, which together with military drill would discipline and transform the man softened by civilian society into a solider hard as metal. ${ }^{55}$

Soldiers were encouraged to become bloodthirsty and to take pleasure in killing and destruction. ${ }^{56}$ Herbert Rosinski builds on this argument and creates an image of the brutal German soldier:

\footnotetext{
52 Heinrich F. Simon from Pannes to Professor Alexander Cartellieri, 19 Januar y 1915, in Bechmann and Mestrup, p. 250. ,Ruhig und kalt erwarte ich mein Schicksal, das mich ja wohl über kurz oder lang ereilt, weiss ich doch, dass uns[e]re Opfer nicht fruchtlos sind.'

53 Ernst Bischoff from Chelstowo to Professor Cartellieri, 6 April 1915, in Bechmann and Mestrup p. 84. 'Der Gedanke an den Tod durchzuckt mich; blitzschnell gleitet das Leben der Vergangenheit an mir vorüber. Das erweckt neuen Lebensmut. „Wir müssen zurück! Es gibt einen Wettlauf mit dem Tode. Wer wagt, gewinnt!',

${ }^{54}$ Walter Hagen, to his father, 26 July 1915, in Bechmann and Mestrup, p. 255. 'Sie wußten ja, was ihnen bevorstand, als sie freudig und hochgestimmt hinauszogen in den Kampf.'

55 Sabine Kienitz, 'Body Damage War Disability and Constructions of Masculinity in Weimar Germany', in Karen Hageman and Stefanie Schueller-Springorum, p. 181.

${ }^{56}$ Donson, p. 102.
} 
Out of it [this new form of war] was born by 1916 a new type of soldier, formed in a hell of fire and mud. In the "front fighter", with his steel helmet, bedraggled uniform, burning eyes, and drawn face, the "war of material" had found its personification: imperturbable, toughened by the daily horror surrounding him, apathetic, resourceful, independent to the verge of insubordination - the man to whom war had become daily, bloody, hard work stripped of all the gay trappings that formerly used to conceal its worst horrors and of all its pseudo-heroics. ${ }^{57}$

Soldiers took on this highly aggressive form for the defence of the country.

Watson attributes decline in support for the war due to war weariness and argues that the longer the war went on, there was more of a decline in motivation: 'Undoubtedly, a key factor undermining men's willingness to continue was fatigue. The physical demands of active service, the long periods away from home and the mental strain of taking constant risks and coping with the death of friends resulted in the increase of "war-weariness". 58 This is a popular view among historians. However, this "war-weariness" was already in place long before 1917. From the very beginning of the war, German soldiers openly expressed their disgust at the war and how soldiers were enticed, essentially forced, to join the war effort.

Soldiers directly attacked the German government in their letters for causing the war. A soldier wrote in October 1914, just shortly after the war began, that: 'Human-beings are slaughtering thousands of other human-beings whom they neither know, nor hate, nor love. Cursed by those who, while not themselves obliged to face the horrors of war, bring it to pass! May they all be utterly destroyed, for they are brutes and beasts of prey. ${ }^{59}$ Another soldier attacked newspapers for inaccurate depictions of the war front, stating: 'They tell only of our gains and say nothing about the blood that has been shed, of the cries of agony that never cease. The newspaper doesn't give any description either of how

\footnotetext{
${ }^{57}$ Herbert Rosinski, The German Army, Pall Mall Press: London, 1966, p. 148.

58 Watson, p. 74.

${ }^{59}$ Anonymous soldier, 2 October 1914, in Witkop, pp. 149-150.
} 
the "heroes" are laid to rest, though it tells about "heroes' graves" and writes poems and such-like about them.' 60

While the war was depicted as a glorious effort by German military and propaganda to encourage enlistment, soldiers evidently protested against such an image and wrote home about terrible conditions. Rather than just condemning war itself, Dr. Rudolf Theis Eden expressed his disgust at what the war meant for the medical profession specifically. In a letter to his wife in March 1915, he strongly protested against the fact that wartime meant that medical standards are lowered: 'a student with such lack of anatomical knowledge would fail the exam. ${ }^{61}$ Eden went on: 'I am particularly repulsed by the lack of critique and especially the lack of conscience of some. If somebody, who up until now was a physiologist and never operated on anything but animals, now drills into the skulls of soldiers. There is no other way of describing that. ${ }^{62}$ Although it cannot be denied that the war was a time of great medical advancements, he did not see it as a time for opportunity. Eden was just frustrated that such inexperienced men now had such power.

I would argue that unpatriotic fever is expressed in a large proportion of letters home. E. C. Goetting stated that 'The German people have not really cared much about politics so far, at least not as much as they should have. ${ }^{63}$ Goetting suggests that perhaps if the German people had been more politically minded at the beginning of hostilities, they might have succeeded in having a very different relationship with the other nations. Otto Schott, writing from Russia to his father in February 1915, described how war itself is not as glorious as they were encouraged to believe: 'Back home I never would have thought how much you can endure, and have to endure, when you are at war.' ${ }^{64}$ Walter Krueger builds on

\footnotetext{
${ }^{60}$ Souchez, 11 March 1915, in Witkop, pp. 72-73.

${ }^{61}$ Dr. Rudolf Theis Eden to his wife Daniela, 24 March 1915, in Bechmann and Mestrup, p. 136. 'einen Studenten mit solch mangelhaften anatomischen Kenntnissen würde man im Examen durchfallen lassen.’

${ }^{62}$ Ibid., in Bechmann and Mestrup p. 137. 'Was mich besonders abstößt, ist die Kritiklosigkeit und vor allem Gewissenlosigkeit mancher. Wenn einer, der bisher Physiologe war und nie anders als an Tieren operiert hat, jetzt Soldaten die Schädel aufmeißelt, so kann ich das nicht anders bezeichnen.'

${ }^{63}$ E. C. Goetting, 8 December 1914, in Bechmann and Mestrup, p. 68. 'Der Deutsche hat sich bisher nicht viel um Politik gekümmert, wenigstens nicht so, wie er es hätte tun sollen.'

${ }^{64}$ Otto Schott to his father, 21 February 1915, in Bechmann and Mestrup, p. 169. 'Ich hätte zu Hause nicht geglaubt, was ein Mensch aushalten kann und muß, wenn er im Kriege ist. '
} 
this argument: 'The war never ended. It only became more horrific. No more talk about chivalric facing each other, man to man. The modern war technology today stands for the culture of humanity. ${ }^{65}$ Krueger was very critical of the development of warfare in World War One, and blamed humanity for developing a war culture that no longer was based on honourable conduct but cruel slaughters of men.

In an effort to keep men motivated to fight, the German military attempted to justify the war by the portrayal of the enemy as aggressive and unfair. Rumours were widely propagated which spoke of the enemy's cruel behaviour: 'The Russians were accused above all of cutting the arms and legs off the men, the breasts off the women. The French and Belgians were accused of gouging out eyes. There were variations and combinations. But the Leitmotiv remained always the same: in the east, hacking and cutting, in the west, gouging. ${ }^{66}$ Such talk no doubt reassured the soldiers that they were doing the right thing by killing the enemy, and not showing mercy; as the enemy themselves did not show mercy either. 'The image of the enemy, and particularly the English (the Germans rarely used the term "British") and the Russians, was an important emotional rallying call guaranteed to whip up xenophobic hatred. ${ }^{67}$ Robert L. Nelson explains that France was also a focus of propaganda, being the hereditary enemy of Germany: 'Images of both friend and enemy from the earlier wars were now echoed in the soldier newspapers, most clearly with the depiction of the French nation as cowardly and "womanly". ${ }^{68}$ The enemy was depicted as unwilling to fight and so to be despised, or as brutal so to be feared and killed at every opportunity. Nelson argues that it was more important for German propaganda to highlight enemy aggression and declarations of manliness and honour for a very specific reason: German soldiers were invading the other countries. As a result, 'Unlike their

\footnotetext{
65 Walter Krüger to Professor Alexander Cartellieri, 26 August 1918, in Bechmann and Mestrup, p. 94. 'Der Krieg hat nie aufgehört. Es ist nur schrecklicher geworden. Nichts mehr von ritterlichem Gegenüberstehen Mann gegen Mann. Die moderne Kriegstechnik bedeutet heute die Kultur der Menschheit.'

${ }^{66}$ H. von Gerlach, 'Die grosse Zeit der Luege' , Charlottenburg, 1926, p. 48, in David Welch, Germany, Propaganda and Total War 1914-1918, Rutgers University Press: New Brunswick, 2000 , p. 61.

${ }^{67}$ Welsh, p. 3

${ }^{68}$ Robert L. Nelson, 'German Comrades - Slavic Whores Gender Images in the German Soldier Newspapers of the First World War, in Hageman and Schueller-Springorum, p. 74.
} 
opponents, the German soldier newspapers were forced to spend an inordinate amount of time "justifying" the existence of German armies on foreign soils. ${ }^{69}$

Particularly because the degree of human suffering and horror occurred at close proximity, it was required of soldiers to show intense physical strength. Stories circulated of German soldiers beating up French, English or Russian soldiers, drowning them and kicking them in an effort to subjugate them. ${ }^{70}$ Soldiers often wrote about the dead bodies of enemy soldiers being scattered around the battlefields. Karl Fritz wrote of the constant scenes of dead enemy bodies in Verdun 1917: 'One grenade buries the dead; another other ýanks them out again. When entrenching oneself, one immediately comes across dead bodies... All looked pale and consumed. ${ }^{71}$ While this is a gruesome description, it does not appear that the sight of dead bodies had traumatised Fritz. Perhaps soldiers managed to cope with seeing the enemies' bodies more than those of fellow men as they were taught that the enemy deserved to die.

In order to motivate men to fight, it was expected that all German soldiers thought of the enemy as horrific beings that need to be eliminated. Despite intense messages through propaganda, German soldiers did not always talk about the enemy soldiers in negative terms. Many letters of German soldiers in fact reveal very different thoughts on the enemy and acknowledge their strength and military capability. Ewald Hess, for example, made no secret of the French army and its success in battle: 'The French artillery fires well and has already caused us many a loss. ${ }^{72}$ Ernst Bisschoff similarly acknowledged Russian success in one of his letters in 1916: 'That despite this [great military advancement] we were still not able to carry the Russians` position, is evidence of the virtue of the enemy`s troops, who despite horrible losses (for every dead German there were 90 dead Russians) and gas attacks (the gas was 13 times as poisonous as prussic acid!)

\footnotetext{
${ }^{69}$ Nelson, p. 81.

${ }^{70}$ Sabine Giesbrecht, 'Volksliedarchiv Deutsche Liedpostkarten als Propagandamedium im Ersten Weltkrieg', Lied und populäre Kultur / Song and Popular Culture, 50./51. Jahrg, 2005/2006, p. 93.

${ }^{71}$ Karl Fritz, Verdun August 1916, in Soldatenbriefe aus dem Ersten Weltkrieg, www.ggeschichte.de, accessed 15 January 2014. 'Die eine Granate begraebt die Toten, die andere resist sie wieder heraus. Will man sich eingraben, kommt man gleich auf Tote... Alle sahen bleich und verzehrt aus.'

${ }^{72}$ Ewald Hess to Professor Alexander Cartellieri, 21 November 1914, in Bechmann and Mestrup, p. 77-78. 'Die französische Artillerie schießt nicht schlecht und hat uns schon manchen Verlust beigebracht.'
} 
held their position with the help of strong, fast approaching back up troops. ${ }^{73}$ In a time in which German soldiers were inspired to praise German might and strength, while simultaneously putting down the enemies' troops, some German men chose to represent enemy troops in a more realistic way; by acknowledging success and defeat on both sides. German soldiers focused more on notions of honourable conduct than ways to degrade the enemy.

Soldiers also sometimes formed close relationships with the enemy at the front. There were numerous occasions, particularly on celebrations such as Christmas, when soldiers from both sides crossed the firing lines to share food, cigarettes and stories with the enemy. Hans Mueller described such an event in a letter from May 1917:

the Russians came out of their trenches this morning, calling, waving, and waving white banners, and they came over to our wire entanglements. Soon our people realised what they wanted; we also came out of our trenches and suddenly and quickly the international fraternization began. We conversed, asked questions, talked about things: the Russians exchanged bread and eggs for our schnapps and cigars, and photographs were taken of many groups of German, Hungarian and Russian soldiers mixing with each other. ${ }^{74}$

It is remarkable to realise the trust the different nations put into the "enemy" by allowing themselves to celebrate in such close proximity together, and the extent to which comradely behaviour dominated over official propaganda of the enemy. Although this kind of bonding was rare, and soldiers quickly seemed to remember their place when the fighting continued, it nevertheless proves the fact that soldiers could not have believed all the things they were told about the enemy;

73 Ernst Bischoff to Professor Alexander Cartellieri, 4 July 1916, in Bechmann and Mestrup, p. 113. 'Daß es uns trotzdem nicht möglich war, die russ[ischen] Stellungen zu nehmen, zeugt für den Wert der uns gegenüberstehenden Truppe, die trotz furchtbarer Verluste (auf einen Deutschen kommen 90 tote Russen) und trotz des Gasangriffes (das Gas war 13 Mal giftiger als Blausäure!) mit Hilfe starker, herbeieilender Verstärkungen sich hielten.'

${ }^{74}$ Hans Müller to Professor Alexander Cartellieri 7 May 1917, in Bechmann and Mestrup, pp. 179-180. 'stiegen die Russen an diesem Morgen aus ihren Gräben, riefen, winkten, schwenkten weiße Tücher und kamen herüber an unser Drahtverhau. Bald hatten die Unsrigen begriffen, was jene wollten, gingen ebenfalls aus den Gräben, und plötzlich und rasch war die Völkerverbrüderung im Gange. Man unterhielt sich, befragte, besprach sich, gegen unsern Schnaps und Zigarren gaben die Russen Brot und Eier; viele Gruppen, Deutsche, Ungarn, Russen durcheinander wurden photographiert.' 
otherwise such brotherly behaviour could not have happened. Soldiers no doubt realised that essentially, everybody was doing their duty as a soldiers of their respective nations. Clearly, not all German soldiers had mastered the cool professionalism, which was to stop them from thinking about the enemy as human beings, but rather as grotesque, cruel creatures which had to be killed.

Furthermore, the German military encouraged mobilization by advertising everybody's duty in the war effort. Ewald Hess stated that 'every order is sacred, and as a small cog in the big war machine, one has the duty to follow orders accordingly. ${ }^{75}$ However, feelings of national togetherness did not dominate all soldiers. The problem was that the German people as a whole were not particularly politically minded at the time of the outbreak of war. 'Heimat [Homeland] enthusiasts, like everyone else, had anticipated a short interruption of normal life, to be followed by a return to old routines and activities after the war was quickly won. ${ }^{76}$ This concept is referred to as Blitzkrieg, where Germany quickly won the war and so people would not even have really noticed that the war ever happened; everything would be back to normal. However, 'The crisis had come far too quickly to leave any time for psychological preparation, and no amount of preparation could have achieved it. ${ }^{77}$ By 1916, traumatised by starvation, cold and defeat, soldiers experienced the psychologically-damaging frustration of having no outlet for the aggressive feelings that wartime propaganda strongly discouraged. It was not patriotic to complain about their situation; true soldiers were meant to endure. Celia Applegate argues, however, that 'Evidently few soldiers concealed from their families the hopeless terror of their situation; some even urged relatives to shrink food production and to refuse war bond subscriptions in order to shorten the war. ${ }^{978}$ This suggests that not only did soldiers sometimes complain about their situation at the front, they also encouraged disorder at home. As will be explained in more detail in the French soldiers' letters on mobilization, this concept of disorderly behaviour is parallel to French soldiers' honesty with their families and defying censors.

${ }^{75}$ Ewald Hess from the trenches at Marcheville to Professor Alexander Cartellieri, 15 November 1915, in Bechmann and Mestrup, p. 160. 'jeder Befehl ist heilig, und als Rädchen der großen Kriegsmaschine hat man seiner Bestimmung gemäß zu arbeiten.'

${ }^{76}$ Celia Applegate, A nation of Provincials - The German Idea of Heimat, University of California Press: Los Angeles, 1990, p. 109.

${ }^{77}$ Rosinski, p. 132.

${ }^{78}$ Applegate, p. 111. 


\section{Mobilizing Masculinity in France}

There was a very close relationship between citizenship and military service in French soldiers' letters. In order to call oneself a respected Frenchman during the First World War, one had to be enlisted in the army. Smith, Audoin-Rouzeau and Becker agree that the 'Patriotic rhetoric in French war culture perhaps had more aggressive and brutal connotations than elsewhere. ${ }^{79}$

While I am reluctant to support the idea that the French national identity is more pronounced than in any other country (which is a popular opinion indeed), I would agree with the idea that citizenship in France made rituals of conscription and mobilization essential rites of the male identity. ${ }^{80}$ Through military service, soldiers proved their loyalty to the nation and would be honoured greatly if they died in service. In fact, soldiers were honoured for various reasons - when they died, but also if they acted bravely or were wounded. Essentially, the physical or emotional harm that was a direct result of being a manly, brave soldier was celebrated in a number of ways. As Leonard V. Smith explains, 'After suffering would come redemption and glorification. This was the tactic bargain of martyrdom - exceptional reward for exceptional suffering. ${ }^{81}$ Martyrdom was to become unproblematic and judging by the French soldiers' letters in this study, it is remarkable to note just how dominant this acceptance of death or injury became to the mentality of the everyday soldier. The authors of France and the Great War 1914-1918 agree with this heroism of the French soldiers and explained that this heroism was deeply embedded into Frenchmen's mind and psyche: 'The writings of the vast majority showed in one way or another the influence of a heroic ethic and a sense of duty assimilated over a long period of time. ${ }^{82}$

\footnotetext{
${ }^{79}$ Leonard V. Smith, Stephane Audoin-Rouzeau, and Annette Becker, France and the Great War 1914-1918 - new approaches to European history, Cambridge University Press: United Kingdom, 2003 , p. 59.

${ }^{80}$ See Sarah Blouen, Marion Demossier and Jeanine Picard (eds.), Recollections of France Memories, Identities and Heritage in Contemporary France, Bergham Books: New York and Oxford, 2000, p. 15.

${ }^{81}$ Smith, 2007, p. 63

${ }^{82}$ Smith, Audoin-Rouzeau, and Becker, 2003, p. 107.
} 
In France, after three years of compulsory military service for men aged between 21-24 years, men were considered reservists until the age of $30 .{ }^{83}$ Compared to German enlistments, 'France's voluntary enlistments were smaller but steadier, reaching 187,905 men by the end of hostilities. ${ }^{94}$ Audoin-Rouzeau and Annette Becker explain that "established" men were the first to enlist: among workers, where just under 30 per cent of the eligible age bracket enlisted [...] Middle-class men enlisted in proportionately even greater numbers; in banking, finance and commerce, the level rose to 40 per cent of those eligible for active service. 85

Calling on the rich history of the French military, the grandeur of France became a key component of the patriotic fever which encouraged young men to join the war. The nation's pride was explored in Monseigneur Baudrillart's statement in the newspaper Petit Parisien in August 1914: 'I think what is happening is a very good thing... I've been waiting for it these last forty years... France is pulling herself together and it's my opinion she couldn't have done that without being purged by war. ${ }^{86}$ Evidently, France had been waiting for an opportunity to prove its worth and grandeur. Smith highlights the fact that even when the disruptive nature of war was largely recognised, and it would have become increasingly more difficult for French propaganda to display the massive loss of live and the destruction of French countryside as necessary, soldiers' spirits were high due to heroic conceptions: 'Heroic conceptions of what war ought to be about did not necessarily vanish as temoins approached the battlefield, or even arrived at it. Wild, optimistic rumours circulated long after there was good reason to believe otherwise. ${ }^{97}$ Army Padre Felix Klein stated in 1915 just how easily the young men of France joined the war effort without hesitating:

\footnotetext{
83 'Conscription in France', December 2013, http://en.wikipedia.org/wiki/Conscription in France\#World War_I, accessed 01/08/14.

${ }^{84}$ Alexander Watson, 'Recruitment: conscripts and volunteers during World War One', http://www.bl.uk/world-war-one/articles/recruitment-conscripts-and-volunteers, accessed 01/08/14.

${ }^{85}$ Audoin-Rouzeau and Annette Becker, p. 99.

${ }^{86}$ Monseigneur Baudrillart, in Petit Parisien, 16 August 1914, in Jean-Jacques Becker, The Great War and the French People, Leamington Spa: Oxford, 1985, p. 30.

${ }^{87}$ Smith, 2007, p. 34.
} 
Heedless of all else, given no backward glance leaving unfinished tasks begun, taking no precaution for the future, completely absorbed in the solemn present, they leave family, undertakings, business. Veni, sequere moi!, orders the country, without further explanation, and, like those called in the Gospel, they follow; they go to the frontier, to battle, probably to die. ${ }^{88}$

This reflects on the general, extremely patriotic attitude of these men. Part of this patriotic fever was to blame the war on Germany. Propaganda posters such as L'insomnie du Kaiser (Fig 1.) depict the Kaiser as haunted by the sight of mutilated women and children. While Germany caused the war, France's effort would end it.

The soldier priest De Chardin built on this patriotic attitude to stop German advancement in his letters home. He was not a war enthusiast, and as Rene Hague explains, 'He had no physical or spiritual training to prepare him for a soldier's life. ${ }^{99}$ Yet he spoke of 'This appetite, this passion for living... this appetite and eagerness to act is something, then, of which we are not completely masters: it's a fountain that springs within us quite independently of ourselves, and we can use it, direct it, but not feed it nor keep it going. ${ }^{90}$ De Chardin thought of this patriotic fever and this eagerness to be a soldier as something that a soldier cannot consciously control; it is something that took them over when they needed it the most. The natural affiliation to be a willing solider was heavily propagated. The newspaper Le Matin reported on this patriotic fever and eagerness to fight as universal among French soldiers: 'Our brave young lads [though injured] are far from beaten. They laugh, joke and beg to be allowed back to the firing line. ${ }^{91} \mathrm{~A}$ Frenchman was born to defend his country and the ideals of freedom the country represented. Clearly keeping this link between manliness and military in mind, de Chardin went on to describe his definition of the perfect soldier:

\footnotetext{
${ }^{88}$ Felix Klein, Diary of a French Army Chaplain, Andrew Melrose: London, 1915, pp. 18-19, pp. 24-27,in Marilyn Shevin-Coetzee and Frans Coetzee (eds.), Empires, Soldiers, and Citizens - A World War 1 Sourcebook, Wiley-Blackwell, an imprint of John Wiley and Sons Ltd: United Kingdom, 2013, p. 12.

${ }^{89}$ Ibid., p. 23.

${ }^{90}$ Pierre Teilhard de Chardin, Beurey-Meuse, 29 June, 1916, in Rene Hague (trans), The Making of a mind - letters from a soldier-priest 1914-1919, London: Collins, St. James's Place, 1965, p. 106.

${ }^{91}$ Le Matin, 19 August 1914, in Jean-Jacques Becker, 1985, p. 37.
} 
There's no doubt about it: the only man who knows [who experiences] right in the innermost depths of his being, the weight and grandeur of war, is the man who goes over the top with bayonet and grenade. In that moment training, of course, and a sort of intoxication play a large part; but even so it is still true that the infantryman leaving his trench for the attack is a man apart, a man who has lived a minute of life of which other men have simply no conception at all. ${ }^{92}$

He concentrated on characteristics of fearlessness, bravery and a willingness to face death. Smith builds on the characteristics of the ideal French soldier by arguing that not only were they expected to face danger bravely, but they were also encouraged to do so in a controlled and intelligent manner: 'A soldier could be considered brave, not because he was aggressive or disregarded danger, but rather because he conserved an integrated and self-conscious, embattle self that persisted to the last moment of life. ${ }^{93}$ Even after having experienced warfare first-hand, the eagerness for the battlefield was strongly promoted and supposed to return to the soldiers' frame of mind. De Chardin boasted about this in his letters: 'For me, of course, a move back to the lines no longer has any of the attraction of novelty...But once the time for action comes around again it's very seldom that my earlier keenness doesn't revive. ${ }^{94}$

When it came to certain aspects of his religious beliefs, however, de Chardin was more reserved and certainly torn. He stated that 'Christian action, by its nature, both detaches one and unites one to our Lord.' 95 Although de Chardin went to war to support his religious mission, he struggled to justify the frequent killing of Germans. While propaganda encouraged Frenchmen to think of their enemy as dehumanized beings, not all soldiers were able to maintain this attitude towards the enemy. It is important to note that the popular attitudes towards the enemy were the driving force behind mobilizing men and wartime masculinity. The French soldiers were taught that the ruthless German people had to be stopped from invading their country and stopped from spreading dangerous beliefs, such as the belief that Germany had rights for expansion and was on an

${ }^{92}$ De Chardin, Hersin - Coupigny, 7 October, 1915, in Hague, p. 72.

${ }^{93}$ Smith, 2007, p. 79

${ }^{94}$ De Chardin, Sermaize, 4 May, 1916, in Hague, p. 115.

${ }^{95}$ Ibid., Zuydcoote, 4 July, 1915, in Hague, p. 58. 
imperialistic quest. 'If German Imperialism had to be destroyed, then the war was a just war at the time. For Pierre Teilhard de Chardin there was no problem of conscientious objection.' 96 Yet de Chardin recognised that 'We must do all we can to lessen death and suffering. We must develop the significance of revealed dogma through a more searching criticism of truth. ${ }^{97}$

Men had to kill the enemy troops indiscriminately to protect their own country. Yet the authors of France and the Great War 1914 - 1918 - new approaches to European history argue that, 'Both Germans and Allies had an interest in restraining violence when there was nothing to be gained by it - and an interest in renewing violence when there was, as in "pitched battle.",98 Furthermore, Smith builds on this idea by stating that 'Stories about killing were either brutal assertions of the cold logic of the Just War or embarrassed, contorted, or self-contradictory stories of exceptions that prove the rule of an underlying humanity. ${ }^{99}$ It appears that current research on the French soldiers' writings concentrates on the idea that soldiers had to be one or the other; either possessing a brutal eagerness for killing the enemy, or feeling ashamed for having killed. I would argue that this is a little more complicated to analyse than it is made out to be. Soldiers were all affected by warfare in different ways; their response to seeing death and killing the supposed enemy varied from soldier to soldier and there were more complex written responses to killing in their letters, rather than either stating enjoyment or shame for having killed.

The French historian Jean-Jacques Becker explains that, in part, patriotic fever among the French soldiers was so dominant due to a consolidated hatred of the enemy. There was a tendency to specifically speak of German cowardice and poor military skill. He quotes a solider referred to in Echo de Paris saying: 'My wound? It doesn't matter... But make sure you tell them that all Germans are cowards and that the only problem is how to get at them. In the skirmish way I got hit, we had to shout insults at them to make them come out to fight.' ${ }^{100}$ Becker additionally quotes the Petit Parisien which diminished German military

\footnotetext{
${ }^{96}$ Hague, p .28.

${ }^{97}$ De Chardin, Nant-le-Grand, 8 September, 1916, in Hague, p. 126.

${ }^{98}$ Smith, Audoin-Rouzeau, and Annette Becker, 2003, p. 110.

${ }^{99}$ Smith, 2007, p. 105.

${ }^{100}$ Echo de Paris, 'Story of a wounded soldier', Nohain, 15 August 1914, in Jean-Jacques Becker, 1985, p. 30.
} 
tactics as cowardly: 'The results of the German attack are insignificant... he [the enemy] is reverting to the encircling tactics that are in his blood. I can honestly say we have nothing to worry about. ${ }^{\prime 01}$ The newspaper Le Matin sums up the general attitude towards Germany by stating in 1917: 'Our heroic defenders will learn with joy that they are about to throw themselves at a foe whom the whole human race considers a noxious breed, the enemy of all civilisation.' ${ }^{102}$ Their patriotic fever was to help them endure difficult situations and encourage bravery and military achievements. This illusion that the war would be quickly won no doubt added to this. Having a look at contemporary newspaper articles, the magnitude of the illusion of a short war is evident. In October 1914 Le Matin quoted a soldier who explained: 'My impression is that the great German army is about to retreat... it is only a question of days... The German objective is to beat and retreat on as wide a front as possible.' ${ }^{103}$ A week later the newspaper continued to report on a German retreat: 'Like a wasp trapped in a clear crystal carate, the vile and brutish [German] army is beating against the walls of its prison... it struggles, damaging itself a little more with every vain attempt. It is wearing itself out...' 104

Despite the hatred for the enemy, it became increasingly difficult to mobilize young French men to fight. Particularly in the later years of the war, this became very difficult. The situation was particularly tense due to tensions within the military and between military men and civilians at home: 'At the front, soldiers manned the guns, huddled in trenches, obeyed orders (sometimes grudgingly or selectively), scrounged for food, contemplated death, and complained about the indolence of shirkers, the indifference of civilians, and the idiocy of commanding officers. At home, women labored long and hard to plant and harvest crops, care for children, and look after the elderly.' 105

${ }^{101}$ Lieutenant-Colonel Rousset, 29 March 1918, Petit Parisien, in Jean-Jacques Becker, 1985, p. 32.

${ }^{102}$ Le Matin, 2 Feburary 1917, in Jean-Jacques Becker, 1985, p. 32.

103 Anonymous soldier, 'dispatch from the war correspondence, Le Matin, 16 October 1914, in Jean-Jacques Becker 1985, p. 31.

${ }^{104}$ Le Matin, 22 October 1914, in Jean-Jacques Becker, 1985, p. 31.

105 Martha Hanna, Your Death Would Be Mine; Paul and Marie Pireaud in the Great War, Cambridge and London: Harvard University Press, 2006, p. 288. 
Soldiers clearly longed for an end to the war: 'Entering the fourth year of war, everyone longed for victory: to bring the men home, end the hardship of separation, and restore the viability of family farms too long deprived of male labor.' 106 Once the initial thrill of enlisting had passed, and once soldiers experienced the true meaning of warfare, soldiers increasingly became more critical of the war effort and self-reflected on what the war was causing them: 'Some fellows say that we are spending the best years of our youth here and that when we get home we will be old and disgusted by the pleasures of the flesh that used to make us so happy.' ${ }^{107}$ As the war had been shown as necessary and glorious, this was something soldiers only truly began to recognise in hindsight.

Soldiers increasingly began to disregard censorship and discussed military organisation and its flaws openly with their family back home. The men were expected to follow the rules set out for them and not challenge the authority or censors. 'As good patriots, citizens were to have faith in their commanders and trust in their men. The calm demeanour of war was as important now, in the early days of September, as ever.' ${ }^{108}$ True patriots would have no need to complain to their families at home or give away military locations, but instead endure silently. Depending on how serious the soldiers breached the regulations of the censors in their letter, determined their potential punishment. In May 1917, for example, people were sentenced to a week's imprisonment for disclosing their locations in letters home. ${ }^{109}$ Soldiers recognised that families were entitled to information and this reflects on the idea that all France was at war - not just the men at the war front.

Censorship was not as efficient as the military leaders would have hoped; as a result 'Censorship was so randomly enforced in the first two years of the war that troops could often get away with writing very openly about where they were and how "hot" their sector was." 110 Indeed, as many letters of this thesis show, "troops ignored the rules the censors sought to impose, gambled on the likelihood that their letters would not be intercepted, and established codes and subterfuges to

\footnotetext{
${ }^{106}$ Hanna, p. 231.

${ }^{107}$ Paul Pireaud, 10 November, 1916, in Hanna, p.121.

${ }^{108}$ Ibid., p. 42.

109 Ibid.,p. 189.

${ }^{110}$ Pireaud, in Hanna, p. 89.
} 
thwart the censors and nullify censorship's numbing effect.' ${ }^{111}$ Pireaud discussed his frustration with the censors in a letter to his wife Marie where he stated: 'Every day you ask me where we are and what we are doing. I have already told you this several times you must not have received my letters. I will give you another description of our military situation. ${ }^{112}$ Although it appears Marie has not received some of his previous letters, which may well have been selected out by the censors, he continues his attempt to disclose military information to his wife. His letters were richly detailed and he also quoted a fellow soldier in one letter home. Pireaud explained that soldiers condemned the censors for intruding into their domestic intimacy. His fellow soldier wrote: 'Those guys are just disgusting to disturb the intimacy of our letters with their curiosity. I no longer dare to speak lightly and with an open heart knowing that those old satyrs might have the pleasure of reading what I am writing, thinking, and feeling.' ${ }^{113}$ This soldier condemns the censors for taking away his domestic freedom. Although he does not discuss military locations, he speaks of the censors in a very negative overtone; a clear break from the obedient French soldier.

While patriotism and the reassurance that France was going to war for a just cause overwhelmingly encouraged militarism, it was also religion that prepared the men for warfare. De Chardin, for example, approached the war with clearsightedness and an all-embracing humanity fuelled by his religious beliefs that few men possessed. He tried to make sense of what was happening around him while at the same time, actively participating in the chaos with a certain eagerness: 'He found himself suddenly both actor and spectator in the foreground of the conflict; he brought to it an eager curiosity and a penetrating eye; he gave his whole being into it, with all his courage as a man and all his faith as a Christian. ${ }^{\prime 14}$ Despite the horrors of war that de Chardin was exposed to, he was able to rely on his religion to offer support and maintain his high spirits: 'And more than ever I believe that life is beautiful, in the grimmest circumstances when you look around God is always there. ${ }^{\prime 15}$ He was fulfilled in his role as a soldier, not due to the love for his country, but due to the fulfilment he has

\footnotetext{
${ }^{111}$ Hanna p. 9.

112 Pireaud, 16 February, 1915, in Hanna, p. 89.

${ }^{113}$ Hanna, p. 191.

114 Ibid.,p. 26.

${ }^{115}$ De Chardin, Rexpoede, 28 May 1915, in Hague, p. 56.
} 
through religion. He stated: 'The Christian souls in my circle are very few in number, but it is as clear as daylight that they are, with rare exceptions, the only ones that are "fulfilled", the only ones that are truly human.'116

Furthermore, he relied on his religion to justify the war and remind him of the just cause: 'And even now, in my bad moments, however awful the future that menaces our country, I still retain this triumphant joy, based on a conviction of the transcendence of God.' ${ }^{117}$ He did not fear getting injured or even dying, not because he looks forward to the rewards and acknowledgments he would receive from the government, but rather the acknowledgment from God: 'if you are wounded, even by a ricochet or a spent bullet, in that great battle, why should you grieve? - Our Lord does not forget those who suffer in his service.' ${ }^{118}$ This statement showed a certain degree of eagerness to have this honour bestowed on himself; you cannot help but notice this feeling of excitement in his letter.

Annette Becker argues that although theoretically religious men should be better equipped, it was 'clear that believers were equally unprepared for this kind of death, mass death, the death of young people - even if for Christians the central message of the passion and resurrection inevitably led them to reflect on death. ${ }^{119}$ Yet I would argue that the belief in another life after death (the relief of suffering by going to a better place) allowed religious men to reflect on the war in a more positive way. Non-religious soldiers did not even have this thought of heaven to comfort them and Becker is underestimating the power of this concept. Religious men faced the idea of death with a completely different attitude. Etienne Derville wrote that the thought of God encouraged him to not be afraid of death: 'Why must one be so afraid of death, in spite of oneself? ... Only one thing makes me suffer, and that is fear. And yet my life here is better because it is harder, nearer to death and to God. Enjoying too many good things makes one risk loving life too much.' ${ }^{, 20}$

\footnotetext{
${ }^{116}$ De Chardin, Rexpoede, 28 May 1915, in Hague, p. 54.

117 Ibid., Nieuport - Ville, 9 April 1916, p. 98.

118 Ibid., Rexpoede, 28 May, 1915, in Hague, p. 57.

119 Annette Becker, War and Faith - The Religious Imagination in France, 1914 - 1930, Berg: Oxford and New York, 1998, p. 19.

${ }^{120}$ Etienne Derville, letter from 6 August 1915, Correspondence et notes, J. Duvivier: Tourcoing, 1921, p. 151.
} 
Historians have been quick to assume that men grew more religious at the front. While some men no doubt did become closer to God, others in turn clearly questioned his very existence. Becker argues that men became more religious in the war as separation from loved ones may be permanent for soldiers, and this encourages a need for spiritual relief. ${ }^{121}$ However, we should be cautious when describing soldiers as religious, simply because they mention God in their letters home. "Religion" is not synonymous with "idealism" and "superstition". Hendrik de Man stated: 'Anybody with some experience of the front will understand that the natural reaction to months and years of danger, hardships, sexual continence, and privation of practically any sort of entertainment, is anything but an inducement to spiritual self-communing.' He went on: 'life at the front has made me superstitious to the extent that even now I find it hard to ascribe my good luck to some "mascot" or other talisman in which I confess to have believed.'122 There is a fundamental attitude of the mind required by any church which makes men turn to religion; others may turn to religion, but cannot actually be described as religious. De Man was one of these men who called on religion temporarily, but more in superstition that it would protect him.

Truly religious men wrote in their letters just how therapeutic and effective religious acts were, for example, the act of praying. A soldier wrote in November 1915: 'Prayers and medals accompanied soldiers to the front: I am convinced that prayers work because God loves prayers... As I leave you I beseech your prayers, for only in prayer can we find happiness, as we wait for better days to follow these terrible ones...' ${ }^{123}$ Another soldier was thankful that his friend prayed for him, particularly as the soldier had not found a chaplain yet to practice religion properly at the front. In January 1915 he wrote: 'I thank you for praying to God for me. I have already looked for a soldier-priest but in my company we don't have any.' ${ }^{124}$ In another letter of 16 June 1915 he goes on: '...You encourage me to do my religious duties, it would certainly be a great comfort, but this is

\footnotetext{
${ }^{121}$ Becker, 1998, p. 3.

122 Hendrik de Man, The remaking of a Mind: soldier's thoughts on war and reconstruction, Scribner: New York, 1919, pp. 206-211, in Marilyn Shevin-Coetzee and Frans Coetzee (eds.), pp.237- 238 .

${ }^{123}$ Correspondence of Abbe Salomon, letter of 21 November 1915 and 17 February 1915, in Annette Becker, 1998, p. 61.

${ }^{124}$ Anonymous soldier to Abbe Salomon, letter of 27 January 1915, Archives from Abbe Salomon, in Annette Becker, 1998, p. 32.
} 
impossible because first of all it doesn't fit in with what we have got to do all day, and beside there isn't any soldier-priest or any chaplain... ${ }^{\prime 25}$ These letters not only touch on the fact that chaplains were scarce among the front, but also explain the anxiety this caused among religious soldiers. In situations where they could not properly do so themselves, they called on their loved ones to pray for them, and they believed this would protect them, and this in turn, encouraged them to fight.

\section{Conclusion}

Both German and French soldiers were mobilized to enlist in the war in a number of ways. Both nations' soldiers expressed particularly patriotic ideas about their homeland through an eagerness to protect their homeland from the enemy. The strongly militarized masculinity in Germany, which encouraged Heldentod, did not prevent soldiers from concentrating on notions of honorable conduct, and they were not afraid to write of enemy military success stories as well as their own success. French soldiers evidently promoted the propagated image of the enemy and had no desire to think of the enemy as human. However, French soldiers remained embedded in families, which was partly due to their geographical proximity and with the very wide nature of conscription.

${ }^{125}$ Anonymous soldier to Abbe Salomon, letter of 16 June 1915, Archives from Abbe Salomon, in Annette Becker, 1998. 


\section{Chapter Two: Fraternity and the Military}

Masculinity during the war largely focused on comradely relationships with fellow soldiers; this no doubt was the case for all nations involved. Men were strongly encouraged to display unity, equality and cooperation. Propaganda urged men to form bonds with other men from all different kinds of backgrounds (including regional, racial, political, and social) in order to improve performance at the front. Evidently, the soldiers would be more reliable and victorious by working together and protecting each other, connected by a common goal.

Great leadership skills were particularly important in the line of fire, and soldiers could only fight bravely if their commander was acting responsibly; this was when they could rely on each other. Smith argues that by 1917: 'Only men who felt individually and totally implicated in the fate of one another, and in the authority ruling over them, could be relied upon under fire. ${ }^{\text {'126 }}$

The war provided the men of the lower strata in society the opportunity to fight along more accomplished men and their sacrifice became just as important as that of the upper class of society: 'Now it was declared that all men who fell in war could die a "hero's death" and be honoured in the national memory as "warrior heroes." Previously, this "title of honour" had been bestowed only upon aristocratic men, above all military leaders. ${ }^{127}$

\section{French Soldiers on Fraternity}

This sense of equality encouraged friendships between different classes and it is this specific sense of fraternity that cannot be stressed enough according to the authors of France and the Great War 1914 - 1918 who explain: 'Soldiers who in civilian life would not even have exchanged words because of class barriers became soul mates in the trenches. ${ }^{, 128}$ The message of soldier equality promoted masculinity above class. Young men became equal to older men, as every man that sacrificed his life on the battlefield was doing so for the same cause - the

${ }^{126}$ Leonard V. Smith, The embattled self-French Soldier's Testimony of the Great War, Cornell University Press: Ithaca and London, 2007, p.111.

127 Stefan Dudink, Masculinities in politics and war - gendering modern history, Manchester University Press: UK, 2004, p. 117.

${ }^{128}$ Leonard V. Smith, and Stephane Audoin-Rouzeau, and Annette Becker, France and the Great War 1914-1918 - new approaches to European history, Cambridge University Press: United Kingdom, 2003, p. 99. 
nation. Suddenly, men from all different kinds of backgrounds, political affiliations and class statuses were encouraged to fight alongside each other for the common cause. ${ }^{129}$ This fraternity was partly encouraged because 'death "on the field of honour" had to be celebrated, glorified and made socially acceptable for all soldiers.' ${ }^{130}$ This concept was extended to the lower classes as well, meaning the possibility of a noble death applied to all. Without a doubt, if class differences were as evident in wartime as they were in peacetime, many men would have decided not to enlist. The contemporary newspaper Echo de Paris explores this concept of a noble death in an article of July 1915: 'But at least they [those killed by bayonetting] will have died a beautiful death, in noble battle... With cold steel, we shall rediscover poetry ... epic and chivalrous jousting. ${ }^{\text {"131 }}$ A letter from the front quoted in Petit Parisien in 1915 states: 'A sudden delirium seizes each of the men. At last, we are going to emerge from our torpor! A storm of steel passes over our heads but leaves us unmoved...' ${ }^{132}$ Ignoring class divisions, this letter touches on the unconditional fraternity of all Frenchmen to fight and conquer the enemy.

Felix Klein wrote in 1915: 'The fact is that we know ourselves no longer; barriers are falling on every side which, both in public and private life, divided us into hostile clans. ${ }^{133}$ He believed that this feeling of brotherhood was present not only at the war front, but also quite strongly at home: 'It is the same [...] The relations between citizens are transformed. In the squares, in the streets, in the trains, outside the stations, on the thresholds of houses, each accosts the other, talks, gives news, exchanges impressions; each feels the same anxiety, the same hopes, the same wish to be useful, the same acceptance of the hardest sacrifice. ${ }^{134}$

${ }^{129}$ Rene Hague, The Making of a mind - letters from a soldier-priest 1914-1919, London: Collins, St. James's Place, 1965, p 23.

${ }^{130}$ Dudink, p. 120.

131 Article in Echo de Paris, Hebrard de Villemeuve, 10 July 1915, in Jean-Jacques Becker, The Great War and the French People, Leamington Spa: Oxford, 1985, p. 39.

132 'A letter from the front', Petit Parisien, 17 May, 1915, in Jean-Jacques Becker, The Great War and the French People, Leamington Spa: Oxford, 1985, p. 31.

${ }^{133}$ Felix Klein, Diary of a French Army Chaplain, Andrew Melrose: London, 1915, pp. 18-19, pp. 24-27, in Marilyn Shevin-Coetzee and Frans Coetzee (eds.), Empires, Soldiers, and Citizens - A World War 1 Sourcebook, Wiley-Blackwell an imprint of John Wiley and Sons Ltd: United Kingdom, 2013, p. 13.

${ }^{134}$ Felix Klein, pp. 18-19, pp. 24-27, in Shevin-Coetzee and Frans Coetzee, p. 13. 
Marylin Shevin-Coetzee and Frans Coetzee describe how specifically people of different religious backgrounds came together in the war, and this is particularly noticeable within the French history of the war. Shevin-Coetzee and Frans Coetzee argue that the Jewish religion profited from the war by making itself more visible among other religions. As it became socially acceptable for people to interact, regardless of their religious affiliations, the general public became much more aware of the different religions, particularly at the front. It became common for chaplains to administer to men of other religions if the appropriate chaplain was not available. Shevin-Coetzee and Coetzee explain: 'Jewish clergy did serve in the field with the major armies to minister to Jewish soldiers, even if on occasion the absence of a rabbi meant that a Christian cleric had to substitute. ${ }^{\prime 35}$ The French soldiers were also buried together in mass graves, where no distinctions between religions were made. This brought religious men together in the grave, but also created stronger bonds for the French soldiers who put the men to rest.

Rene Hague reflects on this comradely simplicity: 'For Pierre Teilhard de Chardin the war was also a great human experience; a chance to act as a person in his relation with men whose life he was sharing. He refused ever to look for or to accept anything that would distinguish him from his comrades, and turned down the amenities his superiors would have been willing to obtain for him. ${ }^{136}$ De Chardin expressed this sense of fraternity and also natural dignity as he did not wish to be acknowledged as doing anything more than the common soldier on the battlefield; he was fighting alongside the other soldiers, rather than striving to be personally acknowledged for his achievements in war. De Chardin was particularly humble yet successful, reflecting on the image of the ideal French soldier. In one of his letters home in 1915 he wrote: 'If there is one thing of which I have become convinced just recently, it is that in relations with others you can never be too kind and gentle in your manner; gentleness is our first source of strength, and the first also, perhaps, of the visible virtues. ${ }^{137}$ This line was particularly striking to read, as it shows the influence of the public expectations of

\footnotetext{
135 Shevin-Coetzee and Frans Coetzee, p. 231.

${ }^{136}$ Hague, p. 29

${ }^{137}$ Pierre Teilhard de Chardin, Montigny Rexpoede, 28 May 1915, in Hague, p 55.
} 
men on French soldiers during the war and in forming strong bonds based on gentleness.

While I certainly do agree with Keene and Neiberg that equality was an important factor in developing friendships, it must be recognised that class tensions were by no means suspended during World War One. ${ }^{138}$ Military organizations are especially well-defined hierarchies, and this was also the case during the course of this war. One of the key areas in which this became evident was the housing and treatment of the different ranks within the army: 'Conditions in the artillery....were, indeed, so superior to those experienced by the poor infantryman - the poilu of French national memory - that many infantry soldiers deprecated those who served in the heavy artillery as shirkers who did not really know what war was like.' 139 While the war was promoted as one of equality, tensions were high as it became evident that this was not always the case. De Chardin mentioned this sense of class separation in one of his letters home, where he discussed the difficulty of adjusting to the bourgeois lifestyle: 'May I confess, just to your ears, that at times I feel terribly tired of the selfish, bourgeois (to put it no worse) surroundings I am imprisoned in?... I must remain on good terms with the "common herd" and keep in contact with it. Pray that God may help me to do so. ${ }^{140} \mathrm{He}$ went on to discuss the regional differences among soldiers that provided a barrier to comradely relations when he was stationed in Rexpoede, at the most northern region in France, bordering onto Luxembourg: 'I am quite helpless when it comes to dealing with the native troops, because of the difference in language and the gulf that separates the two mentalities. In the end, accordingly, it has only been with occasional individuals, officers particularly, that I have been able to act as a priest.' ${ }^{\text {'141 }}$

The limitations of fraternity are furthermore exposed through the hierarchy of the French army. Smith explains that 'a struggle over authority relations took place within the French army over the course of the entire war.' ${ }^{142}$ For the

138 Jennifer D. Keene, and Michael S. Neiberg (eds.), Finding Common Ground - New Directions in First World War Studies, Leiden and Boston: Koninklijke Brill NV, 2011, p. 8.

139 Martha Hanna, Your Death Would Be Mine; Paul and Marie Pireaud in the Great War, Cambridge and London: Harvard University Press, 2006, p. 25.

${ }^{140}$ Pierre Teilhard de Chardin, Rexpoede, 28 May 1915, in Hague, p. 54.

${ }^{141}$ Pierre Teilhard de Chardin, Rexpoede, 28 May 1915, in Hague, p. 54.

${ }^{142}$ Smith, 2007, p. 10. 
common soldier, it was very important to have good relationships with generals, as they were trusted with the lives of the common soldiers. Generals were expected to make the right decisions and display excellent leadership ability. When this was not the case, French soldiers were not afraid to discuss this with their families at home. In May 1917, soldiers condemned high-ranking commanders who had made troops fight a battle they could not win. Fernand Maret, for example wrote to his parents on 1 May 1917: 'It is shameful to see how we are being led; I believe that they have no thought of finishing the war until every man is dead.' 143

This struggle between soldiers and their generals continued quite publicly when Robert Nivelle, the Commander In Chief of the French army, was dismissed on 15 May 1917, and replaced by Philippe Petain, who also 'could not continue the offensive without undermining - perhaps fatally - the morale of his men. ${ }^{144}$ The soldiers were hoping for a speedy end to the war and that if lives were lost, this was done so for a good cause, and not simply because the generals in charge were incompetent leaders.

Fraternity proved more difficult to achieve than was hoped by commanders and politicians. As previously mentioned, soldiers were made equal in the sense that each individual's sacrifice and potential death was truly justified for the greater good of the nation. The indiscrimination of fire, and the horrific fact that over one million French soldiers lost their lives throughout the course of the war, meant that 'Soldiers on the battlefield remained commensurate in that any individual was about as likely to suffer harm as any other. Indeed, the indiscriminate nature of artillery, machine gun, and rifle fire did much to undermine time-honoured distinctions between heroes and cowards. ${ }^{145}$ As a result, French soldiers frequently expressed a sense of individual isolation and worthlessness, as the death of one individual did not seem to matter; it was the collective death of soldiers that mattered. The Third Republic remained a resolutely secular regime - conceptions of mastery of death tended to focus on

\footnotetext{
${ }^{143}$ Fernand Maret, Lettres de la guerre, pp. 14-15, Mantes: Siloe, 2001, in Hanna, p. 205.

${ }^{144}$ Hanna, p. 206

145 Smith, 2007, p. 36.
} 
collective rather than individual survival. ${ }^{146}$ While 'soldiers' accounts from all countries emphasized the impersonal character of mass death, French soldiers letters, in particular, exhibited a feeling of overwhelming personal insignificance on the battlefield'. ${ }^{147}$ Smith argues that 'Indeed, at some level the soldier in uniform would surrender his individuality, notably his individual agency, to the collectivity of his comrades. The armies of the Republic became a representation of the sovereign people.' ${ }^{148}$ Additionally, the army continued to celebrate particularly honourable generals and soldiers and publicly recognised their deeds through ceremonies and publications of their names in newspapers. While this was to be expected, it also meant that 'the sense of abandonment and isolation for those soldiers who failed to live up to social expectations was all too real. ${ }^{149}$ All these factors greatly increased class tensions within the army.

One way in which French soldiers managed to overcome this problem of a large group identity, was to focus on the small group identity of their particular battalions and focus on building close friendships with these fellow soldiers. Staying in small groups and building relationships with few men was part of the contemporary war tactics: 'In the battered, shell-ploughed no-man's land between the trenches the deployment of whole companies and platoons in regular lines was unthinkable. Only by dispersing into small groups and single riflemen could men hope to survive. ${ }^{150}$ In addition to this obvious tactical advantage, smallgroup bonding provided psychological support for soldiers. Small-group bonding provided soldiers with friendships with men that were experiencing the same warthese men knew the horrors of war and relied upon each other to deal with traumatising experiences and provided support to keep focused. As Goldstein explains: 'Small-group bonding is very important to combat effectiveness, because it provides a central motivation for soldiers to participate in battle.'151 Soldiers motivated each other and looked after each other; this was the key to the fraternity of French soldiers.

\footnotetext{
146 Smith, 2007, p. 67.

${ }^{147}$ Smith, Audoin-Rouzeau, and Annette Becker, 2003, p. 91.

${ }^{148}$ Smith, 2007, p. 23.

${ }^{149}$ Keene and Neiberg, p. 110.

${ }^{150}$ Herbert Rosinski, The German Army, Pall Mall Press: London, 1966, pp. 148-149.

${ }^{151}$ Joshua S. Goldstein, War and Gender, Cambridge University Press: Cambridge, 2001, p. 195.
} 
For Pierre Teilhard de Chardin, his fellow soldiers proved vital to keeping his spirits up. Being a very religious man, he relied upon the men for a very specific reason: he could say mass and pray with them. De Chardin constantly discussed the decline in religious men at the front and this was particularly challenging for him. In January 1915, he explained that 'Altogether, my position is still unsettled, and it's a very humble one: you feel very insignificant alongside the combatant troops, and they make you feel it... if I stay here, I shall probably have no difficulty in saying mass, but for the last five days it hasn't been possible-and that I miss. ${ }^{152}$ He gradually became to be recognised as a more established priest at the front and in a letter a few weeks later he wrote: 'I'm rather, of course, in partibus infidelium, but there's no lack of Christians, and I'm the only priest in the regiment.' ${ }^{153}$ He had a clear role here in addition to that of the soldier; a role unique to him alone. De Chardin had aspirations to become the main source of support for his fellow men. He wrote: 'All this, I hope, will gradually establish me as the priest-comrade to whom a man can turn when things go wrong.' ${ }^{154}$ Unlike the majority of soldiers who relied on friendships for themselves and to keep motivated, de Chardin actually strove to build relationships with his fellow soldiers not only to remind himself of his religious role in society, but he wished to use his religious identity to help others - his idea of fraternity stretched to mutual involvements to maintain the relationship.

While this popular idea of manly bonding had these numerous benefits, it also proved difficult to deal with when a friend was lost in battle. Pierre Pireaud describes the funeral of a young soldier from his regiment in great detail in one of his letters home to his wife. Although he was not actually particularly close to the young man, his letter is quite emotional: 'The commandant made a short speech at the graveside. I was right nearby but when the poor widow and his parents came forward to shake his hand. Their distress was painful to see[,] the widow cried out[,] I had to turn my back so as not to see her. That's how much it touched

\footnotetext{
152 De Chardin, Cuvillly, 22 January 1915, in Hague, p. 46.

153 Ibid., Marest, Oise, 5 February 1915, in Hague, pp. 47-48.

${ }^{154}$ Ibid., Montigny, 24-25 February 1915, in Hague, p. 51.
} 
me. ${ }^{155}$ This demonstrates that one did not need to be the closest of friends to be affected by a soldier's death.

As to be expected, however, soldiers became even more emotional when close friends lost their lives. Some soldiers felt guilty when their friends were killed in battle and they themselves were not. Take for example de Chardin who described his frustration at the death of his best friend: 'I am ashamed, as you may imagine, to think that I stayed in the communication trenches while my friends went out to their death. So many of them never came back-first among them, my best friend on the regiment, and the finest soldier I've yet known, poor Commandant Le Febvre.' ${ }^{156}$ De Chardin used particularly strong language here, touching on a feeling of guilt for not having been killed himself. So, while friendships encouraged men to remain motivated and optimistic in battle, they simultaneously could break a soldier's spirits completely when these friendships were lost. The death of comrades reminded French soldiers of the nearness of death and the reality of war. De Chardin explained this in more detail:

What I regret is not having been sufficiently competent, perhaps, to hearten or comfort this or that one of my friends. But until you suddenly learn that they've had a bullet through the head, it seems so unlikely that men whom you see hale and hearty in the line, should meet with so swift an end, that you feel embarrassed at speaking bluntly about its nearness... ${ }^{157}$

Even when soldiers did not personally witness the death of a friend, even when their death had not been confirmed, the possibility of it was all too real. When de Chardin's friend Rousselot went missing in July 1915, he held on to the hope that he could still be found. He wrote in a letter in October 1915: 'I didn't tell you that four months ago he [Rousselot] was reported missing, in the Argonne; we're very anxious about what's happened to him. All is vanity, you see, except holding on loyally. ${ }^{158}$ The idea of a friend's death led to desperation. While propaganda encouraged French soldiers to celebrate the efforts of their comrades, particularly close friends struggled to remain calm when a life was

\footnotetext{
${ }^{155}$ Pireaud, in Hanna, p. 76.

${ }^{156}$ De Chardin, Hersin-Coupigny, 7 October 1915, in Hague, p. 72.

${ }^{157}$ Ibid., Nant-le-grand, 23 August 1916, in Hague, p. 119.

${ }^{158}$ De Chardin, Corons du Maroc, Hersin-Coupigny, 15 October 1915, in Hague, p. 76.
} 
lost. While de Chardin expressed hope for a good outcome to Rousselot's disappearance, his letter is also desperate and impatient.

\section{German Soldiers on Fraternity}

We come across a similarly complex response to the concept of brotherhood in Germany. Herbert Rosinski states that when World War One broke out:

A wave of enthusiasm, carrying everything before it, swept aside all differences of political creed, class, religion, age. For a very short period the German nation experienced the happiness of complete unity such as it had never known before and which sprang from the free will of every member of the community. ${ }^{159}$

Evidently, it would appear that all German people came together as one. While I agree with Rosinski that Germans were definitely inspired to unite, I would argue that this union was much more manageable and realistic for one very specific group within Germany; the soldiers. As soldiers were encouraged to unite for one cause, they simultaneously were encouraged to unite as one army. This meant, in turn, that a soldier's role was to cooperate, assist, and unite with fellow soldiers as brothers.

Friendships at the front were much more strongly encouraged by the German military than the relationships to the people at home, as these relationships between soldiers were considered healthier and more progressive and beneficial in wartime. It was believed that strong comradeship would encourage appropriate soldier behaviour, whereas the bonds with the people at home could encourage negative attitudes towards the war effort. Susanne Michl and Jan Plamper argue this was especially demonstrated in discussions about the causes of shell shock. It was considered more of an issue for soldiers with strong ties to the homefront: "At the war front, where comradeship and a "healthy and strong constitution" of the men is found, lies no risk of infection. However, this risk increases,

${ }^{159}$ Rosinski, p. 132. 
depending on how close one gets to the "home front", i.e. the area of female influence.' 160

The hierarchy within the army worked against fraternity, however, and the army had to work hard to overcome this. Birthe Kundrus states that 'The notion of "camaraderie", for example, permitted fantasies of equality without excluding the possibility of hierarchy. Furthermore, the essence of "camaraderie" was founded not in personalities and individuals, but rather, as Martin Broszat has noted, in "codes and duties". ${ }^{161}$ It is interesting to note that previously, while comradeship was always strongly promoted, there was a limit to this bond: only the upper strata of the military society were included in this. Funck explores this disassociation with certain men of society: 'Also according to the Wilhelminian aristocratic officer's concept, comradeship had the function of a motor in building a closed male community, but, of course, only the socially acceptable men were included. ${ }^{162}$ The aristocratic officer soldier identity was much more restricted than the new soldier that emerged at the outbreak of war in 1914.

The need for restructuring the hierarchy of military masculinity as well as the social hierarchy, searching for a new warlike concept of the officer, became a focus. ${ }^{163}$ The concepts of a heightened soldiery, cool professionalism and the effeminate soldier were altered to fit a much wider group of men: 'In everyday military life, these three concepts of the officer ranks and military masculinity were mixed together and broken up, which also loosened their associations with specific social groups.' 164 For example, while it was very important for the aristocratic soldier to remain abstinent, this view was altered and it was much

\footnotetext{
${ }^{160}$ Susanne Michl and Jan Plamper, 'Soldatische Angst im Ersten Weltkrieg. Die Karriere eines Gefühls in der Kriegspsychiatrie Deutschlands, Frankreichs und Russlands', Geschichte und Gesellschaft, 35. Jahrg., H. 2, Geschichte der Gefühle, Apr. - Jun., 2009, p. 225. 'An der Kriegsfront, wo Kameradschaft und eine ,gesunde und derbe Konstitution" der Manner vorherrschend seien, bestehe noch keine Ansteckungsgefahr. Sie steige jedoch, je naher man der „Heimatfront" komme, d.h. dem weiblichen Einflussbereich.’

${ }^{161}$ Birthe Kundrus, 'Gender Wars the First World War and the Construction of Gender Relations in the Weimar Republic', in Hageman and Schueller-Springorum, p. 169

162 Marcus Funck, 'Ready for War? Conceptions of Military Manliness in the Prusso-German Officer Corps before the First World War', in Karen Hageman and Stefanie Schueller-Springorum (eds.), Home/Front: The Military, War and Gender in twentieth Century Germany, Berg Publishers: Oxford and New York, 2002, p. 49.

163 Ibid., p. 49

${ }^{164}$ Funck, p. 60.
} 
more acceptable for the new soldier to be sexually active. The aristocratic officer's body was a sex-free zone, not a sexually-loaded masculinity.

The German military struggled to transform the ideas of the officer class into one clear layout, however. Marcus Funck explains that the soldier identity evolved constantly and this made it difficult for soldiers to bond: 'it becomes clear that the images of gender depicted in the literature were fragile and constantly threatened and, consequently, military masculinity had to be continually renewed and stabilized. ${ }^{165}$

There was still a clear divide between ordinary soldiers and officers. Watson argues that 'Despite the belief that upper-class men would possess a natural affinity to command, pre-war German officer training did not neglect to reinforce paternalistic values.' ${ }^{166}$ He goes on to argue that 'The constant demand for new leaders to replace casualties or command new units, however, eventually forced both officer corps to adopt a more flexible approach towards recruitment.'167 During the cause of the war, the quality in officers no doubt declined, simply due to the fact that training was not sufficiently provided to deal with the harsh realities of the war front. While training quality decreased, the amount of responsibility the officers had, greatly increased: 'Whereas before the war these men had led platoons of 80 soldiers, by 1916, the low officer establishment of many units meant that inexperienced men were placed in command of companies numbering 150 or 200 other ranks.' 168

As we have seen with the French soldiers' letters, the influence of officers was intense and incapable officers were often attacked. In the German case also, Watson points to the ability of officers being important to the ordinary German soldier: 'On the battlefield, however, officers' power derived primarily from their ability to provide the sense of order, empowerment and safety sought so desperately by soldiers in the midst of chaos and danger. ${ }^{\text {'169 }}$ During hostilities, Offizierhass (hatred of officers), would have increased, with the combination of a

\footnotetext{
165 Funck, p. 45.

${ }^{166}$ Alexander Watson, Enduring the Great War - Combat, Morale and Collapse in the German and British Armies 1914-1918, Cambridge University Press: Cambridge, 2008., p. 119.

${ }^{167}$ Ibid., pp. 120-121.

168 Ibid., p. 131.

${ }^{169}$ Watson, p. 110.
} 
decline in military skill. Yet this change of attitude towards officers does not dominate German soldiers' letters nearly as much as it does in French soldiers' letters. In fact, I have not read a single letter in which a soldier directly describes his officer as incapable, or blames him for a lost battle. Perhaps the hierarchy within the German army really did maintain itself more in the mind of the everyday soldier compared to the minds of the French soldiers, or perhaps censors were simply more to be feared.

Despite the hierarchal organisation of the German army, letters show that officers attempted to bond with the men under their command and earn respect. They often highlighted the heroic acts of their fellow dead soldiers in an effort to reassure themselves, and the soldiers' families at home, that their death was not in vain. Karl Brunner wrote a particularly emotional letter to a young soldier's mother after his death:

Despite his young age he was leading his platoon with devotion, sense of duty and exemplary bravery to the very last moment. The comrades of the regiment and the men of the third company strongly feel the loss of this lovely and humble officer. I, as his battalion commander, can only reassure you that he completed his duty and in face of the enemy died as a hero! ${ }^{170}$

This is a perfect example of Heldentod and demonstrates the strong bond to protect each other and each other's honour, even in death. This letter is also a good example of an officer's formal writing, and their effort's specifically to justify the death of soldiers under their command.

In addition to tensions between officers and ordinary soldiers, the divisions between soldiers of different age groups also made it difficult to form bonds. Bern Ulrich and Benjamin Zieman suggest that general conscription aimed to

${ }^{170}$ Karl Brunner, 23 Juli 1916, in Soldatenbriefe aus dem Ersten Weltkrieg, www.g-geschichte.de, accessed 15 January 2014. 'Trotz seiner Jugend hat er mit Hingabe, Pflichtbewusstsein und vorbildlicher Tapferkeit bis zuletzt seinen Zug gefuehrt. Die Kameraden des Regiments und die Mannschaften der 3. Kompanie beklagen tief den Verlust dieses lieben und bescheidenen Offiziers. Ich, als sein Bataillonskommandeur, kann Ihnen nur versichern, dass er in vollstem Mass seine Schuldigkeit getan hat und als Held angesichts des Feindes gefallen ist!' 
conceal the hierarchy within the army, which maintained class equality. ${ }^{171}$ However there were tensions between different army recruits. Hans Mueller, for example, discussed the tensions arising between different age groups in his regiment:

My life as a soldier attained his distinctive complexion particularly by me being part of a troop of "old people". The average age of the men was initially $34 / 35$ years. There is no doubt that the combat value of such older troops in comparison to younger men obviously diminishes greatly. From the age of 30, the service capability in relation to bodily strength and flexibility of the mind obviously decrease a lot in most people. ${ }^{172}$

The age difference between members of his regiment is quite large and they therefore struggle to keep up with the movements and achievements of other regiments who are made up of younger, fitter people. While age differences between young and older soldiers were meant to be overcome in wartime, this obviously posed a more serious problem for soldiers who found themselves in more danger by belonging to a generally older group of soldiers. Mueller explains that their lives were genuinely more at risk, which evidently would cause tensions between men. Not even German propaganda attempts could overcome such a barrier between soldiers. Let us consider, however, that such criticism of older soldiers is rare, and most soldiers did not discuss this as a problem.

Another issue addressed in some letters is the fact that sometimes soldiers did not agree with their role in the war effort. Comradeship encouraged every soldier to embrace their role within the army as doing something important for the entire soldier community. Yet some soldiers simply could not be happy when being

${ }^{171}$ Bernd Ulrich and Benjamin Zieman (eds.), Christine Brocks (trans.), German Soldiers in the Great War - Letters and Eyewitness Accounts, Pen and Sword Military: South Yorkshire, 2010. p.12.

${ }^{172}$ Hans Müller, to Professor Cartellieri from Boureuilles, France, 9 and 17 September 1915, in Denis Bechmann und Heinz Mestrup, Quellen zur Geschichte Thüringens - Wann wird das Morden ein Ende nehmen? Feldpostbriefe und Tagebucheinträge zum Ersten Weltkrieg, Landeszentrale für politische Bildung Thüringen: Erfurt, 2008, p. 159. 'Mein Soldatenleben erhält seine bestimmte Färbung vor allem dadurch, daß ich einer Truppe von ,alten Leuten“ angehöre. Der Altersdurchschnitt der Mannschaft war ursprünglich 34/35 Jahre. Es unterliegt keinem Zweifel, daß der Gefechtswert solcher älterer Truppen hinter jüngeren Mannschaften wesentlich zurücksteht. Mit Beginn der 30er geht offenbar die Leistungsfähigkeit in körperlicher Hinsicht und die Beweglichkeit des Geistes bei der Masse des Volkes sehr zurück.' 
denied certain roles. Johannes Winzer explores the eagerness for the battlefield which he has so far been denied due to more tedious duties:

All of us war volunteers are very angry to be doomed to this truly soul-destroying monotony of the garrison service during these days of global historic significance, which only poses little challenges to us, such as field duty exercise, night marches, ordnance exercises, and is for the most part restricted to foot exercises like "saluting by putting the right hand to the headgear" and other formalities like that...The only thing holding us up is the hope for eventually being given the opportunity to come into action in this deciding battle. ${ }^{173}$

Perhaps not considered a serious divide within the German army, there is mention of tension between soldiers that had different duties. Winzer explained the desire for the battlefront and that soldiers who had to perform night marches and training exercises grew particularly unsettled and experienced some jealousy of soldiers who got to experience the battlefield. There was evidently a hierarchy within the army which distinguished between beginner soldiers and 'real soldiers'.

German soldiers were able to overcome certain barriers of fraternity through the development of individual friendships. Funck rightfully states that 'Comradeship was thought of as an "indispensable binder" which apart from discipline and obedience was the primary factor that kept an army together. Without "Mannzucht" the army would degenerate to an unrestrained troop, without comradeship the life of a soldier would be equal to an unbearable existence.' ${ }^{174}$ Soldiers relied on each other in a number of ways and this encouraged not only a broader brotherhood of the army, but more specifically that front community that we have seen in French soldiers' writings as well. The

173 Kanonier Johannes Winzer, to Professor Alexander Cartellieri, 22 November 1914, in Bechman and Mestrup, p. 72-73. 'Wir Kriegsfreiwilligen alle sind sehr ärgerlich, in diesen weltgeschichtlichen Tagen zum wirklich geisttötenden Einerlei des Garnisonsdienstes verdammt zu sein, der nur sehr wenig Aufgaben wie Felddienstübungen, Nachtmärsche, GeschützExercieren an uns stellt und sich zum grössten Teil beschränkt auf Fuss-Exercieren wie „Grüssen durch Anlegen der rechten Hand an die Kopfbedeckung“ und andre Aeusserlichkeiten.. .Nur die Hoffnung, doch noch einmal selbst mit eingreifen zu dürfen in diesen Entscheidungskampf, hält uns aufrecht.'

174 Thomas Kuehne, 'Comradeship Gender Confusion and Gender Order in the German Military, 1918 - 1945, in Hageman and Schueller-Springorum, p. 240. 
soldiers' resourcefulness and relationships came together to something resembling a "front community".

Paul Liss wrote that despite having different ranks, soldiers straight away feel as one: 'but despite all militaristic differences of ranks one does normally feel straight away this feeling of togetherness. ${ }^{175}$ Johannes Winzer from Karlsruhe similarly stated: 'I was always amazed what an impressive educator war is; personally, ethically and through the bond of comradeship between young and old field soldiers, also nationally and politically. ${ }^{\text {'176 }}$ It appears some soldiers felt that all kinds of different beliefs, affiliations and personalities could be accommodated under comradeship and automatically formed friendships.

Soldiers relied on fellow men for emotional support traditionally associated with women. Due to the separation from women, men had to comfort each other. Liss explained: 'And mostly you also stay more or less in close contact, exchange thoughts, which lately more often evolve around politics; swap books, or share a magazine etc.' ${ }^{177}$ The fact that soldiers would open up emotionally to their comrades demonstrates that soldiers took on certain womanly characteristics by listening and supporting their fellow comrades.

As well as providing one another with emotional security, soldiers were also expected to protect each other physically. This seems to be quite an obvious feature of the masculine concept of brotherhood, but it stands out in German soldiers' letters. Rescuing each other was at the focus of comradeship: 'A central component of "comradeship" was the myth of the reciprocity of loyalty and fraternity unto death, the conviction that comrades were ready and willing to put their life in danger to rescue a friend. ${ }^{178}$ Ernst Bisschoff wrote in 1915 of his own

175 Paul Liss to Professor Alexander Cartellieri, 8 Dec 1917, in Bechmann and Mestrup, p. 146. 'aber trotz aller militärischer Rangunterschiede empfindet man doch meistens sofort etwas von Zusammengehörigkeitsgefühl.'

176 Johannes Winzer, to Professor Alexander Cartellieri, 2. April 1915, in Bechmann and Mestrup, p. 146. 'Ich habe immer wieder gestaunt, was der Krieg für ein ungeheurer Erzieher ist, persönlich, ethisch und durch das Band der Kameradschaft zwischen jungem und altem Feldsoldaten auch national, politisch.'

177 Paul Liss to Professor Alexander Cartellieri, 8 December 1917, in Bechman and Mestrup, p. 146. 'Und meistens bleibt man auch in mehr oder minder enger Fühlung, tauscht seine Gedanken aus, die sich in letzter Zeit immer öfter um Politik drehen, wechselt Bücher, hält sich wohl auch zusammen eine Zeitschrift u.s.w.'

${ }^{178}$ Robert L. Nelson, 'German Comrades - Slavic Whores Gender Images in the German Soldier Newspapers of the First World War', in Hageman and Schueller-Springorum, p. 72. 
attempt to save a wounded comrade from enemy fire: 'Without thinking about it, I invited the wounded man to lean on me with all his weight. He did so, and slowly, painfully slow we moved. It seemed like an eternity before we reached the protecting trench, yet it had only been minutes! I remained completely unharmed! God and my lucky star came to my defence and faithfully protected me. ${ }^{179}$ Patrick Porter points out that 'Field hospital chaplains, for example, were under no illusions about the horrific nature of war wounds, yet precisely the severity of their sufferings lent soldiers' wounds or corpses even greater sacrificial value. Suffering on others' behalf was more ideal if that suffering was real and harrowing. ${ }^{180}$ Even when soldiers were not successful in their rescue attempts, they were still expected to be there for the dying soldier: 'Stories of men extending a "loving hand" like "mother" to ease the pain of the dying existed alongside articles that dealt with the heart - wrenching loss of an extremely close comrade in battle.' ${ }^{\prime 11}$ Quite clearly, German comradeship consisted of both masculine and feminine components.

The death of fellow soldiers is frequently discussed in German soldiers' letters and this allows us to see the various ways in which soldiers viewed and coped with their friends' death. Writing from the Somme in August 1916, Anton Holzman stated: 'Here it is miserable like nowhere else; nobody who is gravely injured can be brought back, they have to suffer in the glowing heat. The dead cannot be buried, they tower up to mountains and remain upright, with five, six lying on top of each other. Then heavy grenades appear, exposing everything and ripping them apart again.' 182 Holzman's letters showed frustration at the fact that some people cannot be saved and have to suffer on the battlefield, with the

${ }^{179}$ Ernst Bischoff aus Chelstowo to Professor Cartellieri, 6 April 1915, in Bechman and Mestrup, p. 85. 'Ohne mich lange zu bedenken, forderte ich den Verwundeten auf, sich kräftig auf mich zu stützen. Er tat es, und langsam, furchtbar langsam ging es weiter. Eine Ewigkeit erschien es mir, ehe wir den schützenden Graben erreichten, und doch waren's nur Minuten gewesen! Ich war ganz unverwundet geblieben! Gott und mein Stern hatten mich in ihren Schutz genommen und treu behütet.'

${ }^{180}$ Patrick Porter, 'New Jerusalems: Sacrifice and Redemption in the War Experience of English and German Military Chaplains', in Pierre Purseigle (ed), Warfare and Belligerence Perspectives in First World War Studies, Brill: Leiden and Boston, 2005, p. 106.

${ }^{181}$ Nelson, p. 72.

${ }^{182}$ Anton Holzmann, August 1916, in Soldatenbriefe aus dem Ersten Weltkrieg, www.ggeschichte.de, accessed 15 January 2014. 'Hier ist es Elend wie niergends anders, kein schwer Verwunderter kann zurueckgeschafft werden, sie muessen erschmachten in Gluthitze. Die Toten koennen nicht begraben werden, sie tuermen sich zu Bergen und stehen aufrecht da und liegen fuenf, sechs aufeinander. Dann kommen schwere Granaten und decken alles zu und reissenn's wieder auf.' 
humiliation of having their dead bodies reburied constantly. The death of a soldier was always supposed to be heroic and inspire fellow soldiers as Leonard V. Smith explains: "The death of any individual could be construed, as contributing to an archetype, an idealized, universal, yet very male identity that would live forever to inspire posterity. ${ }^{183}$ However, there was nothing noble about the scene Holzman is describing. He protested against the undignified deaths of his comrades.

Most of the time soldiers attempted to provide their comrades with a respectable resting place to show their appreciation. Walter Hagen explains that soldiers were not forgotten when they died. He explains that their gravesides were always nicely decorated. Particularly the last phrase demonstrates how strongly comradeship was embedded into the soldiers' mind as vital to masculinity:

Today is Sunday. I was on the graveyard early in the morning. More than 2000 fallen comrades are buried here. A deep silence reigned over this beautiful sacred place, and only rarely does the roar of the guns betray the closeness of the Front. Every grave was decorated, and a cross marked every hill. Wherever they fall, all are placed to rest at a sacred site. German comradeship remains faithful until death. ${ }^{184}$

German soldiers aimed to glorify the death of their comrades. Walter Flex's letter from September 1914 wrote about the death of a comrade called Petz and also specifically writes about Heldentod. He wrote: 'I then sat among the comrades in the city's church where the two of you were married, and tried to understand what had happened. But I could not stop the tears. ' He continued: 'We have to try and look at dear Petz's Heldentod from his point of view; this will give us the most strength. Surely the length of a lifetime does not matter; what matters is the degree of happiness we experience and give in a lifetime. ${ }^{185}$ It is

\footnotetext{
${ }^{183}$ Smith, 2007, p. 67.

184 Walter Hagen from the eastfront to his father, 26 July 1915, in Bechman and Mestrup, p. 255. 'Heute ist Sonntag. Ich war früh auf dem Friedhof. Hier ruhen über 2000 gefallene Kameraden. Tiefe Stille lag über dem schönen geheiligten Orte, und nur ab und zu verriet Kanonendonner die Nähe der Front. Jedes Grab war geschmückt, und ein Kreuz zierte jeden Hügel. Wo sie auch immer fallen, alle werden an geheiligter Stätte zur letzten Ruhe gebettet. Deutsche Kameradschaft hält Treue bis in den Tod.'

${ }^{185}$ Walter Flex to his parents Rudolf and Margarete, and his brother Konrad, 20 September 1914, in Bechman and Mestrup, p. 249. 'Ich saß dann in der Stadtkirche, in der Ihr getraut wurdet, unter
} 
interesting, first of all, that Flex is not afraid to write about his own tears and pain. Although not considered manly at all, he can open up emotionally to his parents about his comrade's death. The fact that he tries to justify Petz's death in a number of ways-referring to the death as Heldentod and celebrating his life shows that soldiers could not always cope with their comrades' deaths and they had to make sense of it.

Even though soldiers were taught about their expendability, as we have seen in chapter one, Albert Lepiner's letters show that soldiers greeted death with a sense of disbelief. In December 1914 he wrote: 'Here I saw Otto and we walked towards each other and shook hands and he even said that I should be careful today, as today would be a tough day... and within the next five minutes he must have fallen, not even 15 metres away from where we spoke. ${ }^{186}$ Lepiner is clearly in disbelief regarding the death of his friend and protests against the idea that soldiers should simply accept death for themselves and their comrades.

\section{Conclusion}

Although soldier equality was promoted strongly in both the French and German army, there were tensions between ideas of fraternity and the hierarchy of the army. Especially in Germany where they did not have the revolutionary tradition as they did in France, there was a need for the traditionally aristocratic nature of the officer class to evolve to include men of all backgrounds. Letters reveal how soldiers focused on a smaller group identity to overcome the obstacles of the hierarchy of the army. Men bonded with the men closest to them and this meant that both French and German soldiers could be deeply affected by the death of a fellow soldier. Attitudes towards death as expressed in letters reveal that although soldiers accepted their expandability, the death of a friend could be particularly difficult to make sense of.

den Kameraden und suchte das Geschehene zu fassen. Aber ich konnte die Tränen nicht halten.' he goes on: 'Wir müssen des lieben Petz' Heldentod mit seinen eigenen Augen zu schauen versuchen, das wird uns am meisten Kraft geben. Sicher kommt es nicht auf die Dauer des Lebens an, sondern auf das Maß des Glücks, das in ihm erhalten war und das von ihm ausging.'

${ }^{186}$ Albert Lepiner, 15 December 1914, in Bechman and Mestrup, p. 4. 'Hier sah ich Otto noch und wir gingen aufeinander zu und haben uns die Hand und er sagte noch, ich sollte heut aufpassen, denn heute gaeb's einen harten Tag... und in den naechsten fuenf minuten muss er gefallen sein, kaum 15 Meter davon entfent, wo wir mit einander gesprochen haben.' 


\section{Chapter Three: Protection of Women}

While the young men of France and Germany went to war for a number of reasons, the concept of protecting their families was particularly important. While men were encouraged to be proud, strong and fearless soldiers ready to die for their country, women were displayed as fragile and defenceless against enemy soldiers. These gender norms were used in propaganda and newspaper rhetoric as a tool to entice men to fight. Despite this, there were a number of ways in which men attempted to protect their women and they were not purely through the act of enlisting. While some soldiers simply avoided certain topics in their letters altogether to prevent women from worrying, others used specific techniques in their letters to draw attention away from the seriousness of the topics they discussed. When analysing the letters soldiers wrote home to their mothers, sisters, lovers or any other female family member, it is evident that soldiers were well aware of their role as the protector, while they also reinforced the need to shield their women from the brutalities of war.

This is not to say, however, that soldiers did not challenge these gender norms. Their letters often revealed a reliance on women to help them survive war; the gender roles were clearly reversed in the sense that women were the driving force behind maintaining soldiers' spirits and surviving the horrors of war. This was particularly important in the later years of the war, as morale diminished and the illusion of a short war disappeared. The very act of writing letters was therapeutic for soldiers as putting the experience down in writing stabilised the experience and the identity of soldiers who experienced war. It allowed soldiers to write what they felt comfortable with; they could choose to reflect on the war experience as they saw fit and could justify their actions as well. Writing to women allowed soldiers to represent themselves in a different light, and play down the dangers of war. As Joshua S. Goldstein suggests, 'Women collectively, then, serve as a kind of metaphysical sanctuary for traumatized soldiers, a counterweight to hellish war. $^{187}$

${ }^{187}$ Joshua S. Goldstein, War and Gender, Cambridge University Press: Cambridge, 2001, p. 304. 


\section{French Soldiers on Protection of Women}

French propaganda posters demonstrate how women were the driving force behind men going to war. The posters titled Aux armes, citoyens! (Fig 2.) and Allons, enfants de la patrie. (Fig 3.) embodied France as a strong woman that guides men to the battlefront. The normal French women, however, were not that powerful - they needed their men to fight for them. Perhaps these posters symbolically show that women were strong in the sense that they motivated men to the front, but relied on their protection from then onwards. Women were not meant to know about the horrors of war; the brutality or serious injuries that some men suffered from.

It was not uncommon for soldiers to write about heroic acts of others, and how they themselves craved for the opportunity to be in the front line to experience warfare and kill the enemy. Jennifer D. Keene and Michael S. Neiberg explain that "Real" men were expected to distinguish themselves through displays of strength, discipline and courageousness. Nervousness, passivity and weakness, on the other hand, were traits generally attributed to women. ${ }^{188}$ Pierre Teilhard de Chardin touched on this idea by describing his longing for the front line: 'at last, I've had a spell in the trenches; not yet in the heroic trenches where your feet get frozen and bullets rain down, but still in real front-line trenches, right next door to the Boche, where you hear the whistle of shells and the crack of bullets if a head shows over the parapet for too long.' ${ }^{189}$ Even when he had experienced the 'heroic trenches', he still felt a longing for them when on leave: 'In a week's time, if they leave us idle for so long, I shall no doubt feel a nostalgia for the firing line, but for the moment I am allowing myself to relax. ${ }^{\text {'190 }}$ Such words no doubt helped to put the women at home at ease, as their soldiers seemed to strive for the excitement of the front.

French soldiers used a number of techniques in their letters to try and distract from the seriousness of war so that their wives would not worry about them too

\footnotetext{
188 Jennifer D. Keene and Michael S. Neiberg (eds.), Finding Common Ground - New Directions in First World War Studies, Leiden and Boston: Koninklijke Brill NV, 2011, p. 89

189 Pierre Teilhard de Chardin, Montigny 24-55 February, 1915, in Rene Hague (trans.), The Making of a mind - letters from a soldier-priest 1914-1919, London: Collins, St. James's Place, 1965 , p. 50.

${ }^{190}$ Ibid., Rexpoede, 28 May, 1915, in Hague, p. 53.
} 
much. One of these techniques is the use of humour in their letters. One Frenchman in particular evidently used a lot of humour in his letters home: Pierre Teilhard de Chardin. In a letter dating 14 July 1916, he made a reference to playing a children's game with the German bombs landing around his base: 'you had to play hide and seek with the various sorts of bombs and grenades that might at any moment land among us, their arrival heralded by the short sharp report of their firing.' 191 This image truly derails from the severity and horrific damage the bombs could inflict on impact, but instead proposes that the soldiers had fun dodging bullets and bombs by making a game of it. While this quite clearly would not have been the case, he attempted to lighten the mood in his letter.

De Chardin also discussed other dangers of war within an amusing concept. For example, he wrote: 'Only the mud is still in full control; and so yesterday you might have seen me going about plunged above my knees in glutinous mud, at the bottom of one of those crumbling and shell-torn ditches we dignify by the name of communication trenches. Fine weather indeed!' ${ }^{192}$ The sarcastic overtone of this statement 'Fine weather indeed!' distracts from the very serious threat posed by the treacherous mud. A main feature of the war front, mud threatened the lives of soldiers in a number of ways; in addition to soldiers drowning in mud, the mud could also flood and destroy the trenches dug out by soldiers and promoted the spread of disease as soldiers got stuck in mud due to their clothes and weapons being weighed down by it. Soldiers additionally had to take extra care to prevent mud from getting into the barrel of their rifles. He chose not to mention any of these threats posed by mud in his letters, but instead focused on making the situation appear better than it was.

Additionally, French soldiers refrained from expressing violence in too graphic descriptions of events. While many soldiers were particularly frank in their expressions, they always maintained a sense of control. Whether it was in regards to describing heroic actions or discussing wounds, French soldiers were expected to follow this concept of a 'heroic silence' in which they would suffer in silence and not complain. While soldiers were allowed to speak of bravery, as this was expected of soldiers, it was important not to exaggerate or brag. Take for

${ }^{191}$ De Chardin, Dunes de Zuydcoote, 22 August 1915, in Hague, p. 66.

192 Ibid., Esnes, 14 July, 1916, in Hague, p. 11. 
example, de Chardin, who 'since he was writing to those who were near and dear to him, $[\ldots]$ deliberately minimized his own danger and makes no mention of his own courageous deeds, for which he was three times mentioned in Army and Divisional Orders, and was awarded the Croix de Guerre, the Medaille Militaire and the Legion d'Honneur. ${ }^{\text {'193 }}$ De Chardin spoke of an eagerness to participate in battle, but never mentioned personal acts of bravery in boasting terms.

Blandness was quite an important feature of French soldiers' letters, as I did not come across any overly-brutalized terminology in their letters. Etienne Derville would have been one of the most descriptive by stating:

I have been wounded twice within fifteen days, and the shock was so violent and the part of my body struck so crucial, that both times I believed I was only a few moments from death. And, you see, I keep an ineffaceable memory of these moments... This sacrifice will be even more easy and joyful now, because I have reflected a great deal on it since then. ${ }^{194}$

But even in this letter, there was no detail as to what his actual injury was and he also assured his family at home that his wounds were necessary for the war effort. He seemed fearless in his letter and although his injuries were in fact life threatening, his description still appeared subdued and controlled.

Anna Green raises the idea that this may have been done unintentionally, as the soldiers probably only strove to minimise descriptive writing of wounds as a defence mechanism for the soldiers themselves in order to cope with their wounds and deformities. She explains that 'The value of personal memories, as we shall see, lies in the attempt to make sense of, and reconcile, unique material and subjective experiences.' ${ }^{195}$ Green goes on to discuss Alistair Thomson's study on composure and memory, in which "Thomson argues that "composure" is an apt name for a process through which an individual seeks to make sense of their lives, reconciling past and present to achieve a sense of composure, to feel

\footnotetext{
${ }^{193}$ De Chardin, Esnes, 14 July, 1916, in Hague, p. 28.

194 Etienne Derville, 1 January 1915, in Leonard V. Smith, The embattled self - French Soldier's Testimony of the Great War, Cornell University Press: Ithaca and London, 2007, p. 65.

${ }^{195}$ Anna Green, Cultural History, Palgrave Macmillan: New York, 2008, p. 88.
} 
comfortable about the past.' ${ }^{196}$ Stories of pain and fear would have been forced into silence precisely as part of the procedure to reconcile the war experience. I agree that sometimes it is difficult to know whether soldiers consciously or subconsciously strove to minimise descriptions of wounds. Yet in certain cases, and after reading countless letters of one soldier, one does get to know the individual quite well, and we can determine whether something was written purposely or not - in de Chardin's case, one can determine that he consciously strove to minimise the seriousness of his war wounds to protect his family at home. All his letters follow a very distinct pattern of composure, seriousness and were well planned out; one does not get the impression at all that he wrote something home that was uncontrolled or subconsciously written.

Even though soldiers were separated from their families, they never strove to forget their domestic roles as the provider and defender of the family. Whether the men enlisted due to their religious identity, their regional origins or political affiliations, their family seems almost always to be the main driving force. Many soldiers needed no other reason but the protection of their families to maintain themselves throughout the war years. Consider, for example, Paul Pireaud: 'He did not seek consolation in religion, nor was it patriotic fever which got him through Verdun - it was luck and the thought of his family.' ${ }^{197}$ It is evident that the French soldiers put their families first. Although the French state moved quickly in August 1914 to introduce military allowances for households whose principal breadwinner had been mobilized, poverty was still wide-spread and caused extreme food shortages in many regions. ${ }^{198}$ Grain and grapes were the staple food and were in short supply partly due to German troops destroying crops and orchards during occupation of northern France and on their retreat toward the Hindenburg line in $1917 .{ }^{199}$

The soldiers' idea of protection extended to maintaining their domestic roles in families. One of the ways soldiers did so was through money management discussions in their letters. The French soldiers frequently wrote to their wives

\footnotetext{
196 Green, p. 93

197 Martha Hanna, Your Death Would Be Mine; Paul and Marie Pireaud in the Great War, Cambridge and London: Harvard University Press, 2006, p. 79.

198 Ibid., p. 53.

199 Ibid., p. 193.
} 
and advised them to keep their money to buy food as they themselves were well provided for. ${ }^{200}$ Although this certainly was not the case for many of these soldiers, they nevertheless never failed to reassure their families at home not to worry in regards to material things. When reading the soldiers letters with this in mind, I was specifically impressed by Paul Pireaud's ability to maintain this attitude throughout the war. In 1915 he wrote: 'I thank you from the bottom of my heart for your devotion on my behalf and I would like to be able to thank you directly and to save you all your fears that you must have because I can see from here what our poor countryside must be like each time that we talk about it among my buddies tears come to my eyes. I beg of you keep your money, I have less need of it than you do. ${ }^{201}$ Even two years later, in 1917, he maintained this protective attitude and reassured his wife:

Don't worry yourself [.] I am not as unfortunate as you think. It's really cold here but I have my galoshes [,] my sheepskin [,] my overcoat [,] and my beret and I will be able to face whatever winter throws at me. You can rest assured on this matter. Our little one must be suffering more from winter than I am...How long it will be till I can go home and kiss him and his maman too. How happy I will be on that day. ${ }^{202}$

While certain other aspects of the ideal masculine soldier certainly diminished over the course of the war, this desire to provide for women and children at home never faded.

French soldiers furthermore managed to maintain their role at home through discussions of child rearing. A lot of countries struggled to keep their population growing, but France specifically was affected by this: 'Only by saving its infants from an untimely and now unavoidable death, could France, the nation with the lowest birth rate in Europe, hope to defend itself in the future. ${ }^{203}$ Feeling a strong bond towards family, the French soldiers often spoke of fatherhood in their letters home and did what they could to encourage healthy pregnancies. Paul Pireaud often wrote to his wife with hopes of becoming a father and often reading news of

${ }^{200}$ Pireaud, 17 January 1917, in Hanna, p. 189.

${ }^{201}$ Pireaud, 30 May 1915, in Hanna, p. 60.

202 Ibid., 17 January 1917, in Hanna, p. 188.

${ }^{203}$ Hanna, pp. 129-130. 
Mary as a sign of pregnancy, for instance when she mentioned in a letter that she was sick. Although Mary could have been sick for a vast number of reasons, all he replies is: 'You tell me that you are sick could this not be a sign of pregnancy?'204 He went on to confide in her that 'the love he and Mary had for each other and the joys of fatherhood were all that sustained him in the face of relentless adversity.' 205 Once her pregnancy was confirmed, he did all he could from afar to take on his role as a father and protect his child. While Mary was still in her first trimester, he urged her to consult a doctor and asked her to drink milk on a daily basis. ${ }^{206}$ This demonstrates that although the image of the proud and strong soldier was overwhelmingly represented in propaganda at the time of war, French soldiers did not let this affect their role as a father and provider in peacetime.

Religious men also incorporated a religious element into the concept of protecting women at home through letters that spoke of church going and other religious acts. These soldiers described how religion connected them to their families during long periods of separation. Masson wrote on 13 May 1915: 'I was able to go to a very early morning mass and take communion. How close I felt to you in that most intimate union with Him who sustains us.' On All Saints Day 1915 he wrote to his wife: 'I bear you close to God. May He be the link of eternity between us. ${ }^{207}$ Not only were Masson and his wife connected by the act of letter writing, it is also the everyday acts like praying, and going to mass, (that his wife would simultaneously be doing at home), which created a strong bond. While his writing encouraged pious behaviour, Pierre Tisserant acknowledged his family's pilgrimage to religious sites also and reflected on the fact that this pilgrimage protected him:

Poor little Maman, I can still see you on pilgrimage to Notre-Dame des Victoires and to Sacre-Coeur, and I especially see you praying steadily all night for me. I must be well-protected by this network of prayers, but on the other hand you should not worry so much, especially

\footnotetext{
${ }^{204}$ Pireaud, September 1915, in Hanna, p. 131.

205 Hanna, p. 3.

${ }^{206}$ Pireaud, in Hanna, p. 135.

${ }^{207}$ Pierre-Maurice Masson, 1 November 1915, Lettres de guerre 1914-1916, Hachette: Paris, pp. 95, 151, in Annette Becker, War and Faith - The Religious Imagination in France, 1914 - 1930, Berg: Oxford and New York, 1998, p. 40.
} 
since I am in a relatively calm sector... I thank all three of you for the trouble you took to go to Sacre-Coeur during the period of action I am going through. ${ }^{208}$

Evidently, he appreciated the act, but worried about his mother's well-being at the same time for travelling far; what would be recognised by contemporary society as a truly religious, good man.

Furthermore, religion was incorporated in letters to justify deaths of fellow soldiers to help their widows deal with their loss. Let us consider, for example, a letter Pierre-Maurice Masson wrote to the wife of one of his cousins killed in action in February 1915. He wrote:

What is moving and magnificent in this death is the fact that it was accepted months ago with the most serene courage, and that he seemed to love you as much as he did in order to have more to sacrifice to the duty that claimed him; showing in this final gesture of a Christian knight that there are cases where, to fulfil the beauty of a life, one must know how to lose it. ${ }^{209}$

It is interesting to see that although Masson had lost a family member himself, he considered how he can help his cousin's widow feel more at peace with the death first and foremost. He explored the unconditional love his cousin had for his wife, but also brought the religious element into this statement. He reflected on his cousin's appearance of being Christ-like; he was an imitation of Christ in the trenches. Evidently of a religious background, this would be particularly comforting to the widow.

Despite the numerous examples of soldiers expressing a desire to protect women, the role of protection could break down. Some soldiers' letters show just how afraid they were of the war experience by writing about their mental breakdowns. Such letters were not designed to protect women from worrying, but instead may have caused more concern on the women's part. For example, Infantryman Emmanuel Lemercier wrote on 21 September after a particular horrific shelling experience: 'When these torments were finally over, I had such a

208 Pierre Tisserant, 5 December 1916, Lettres 1914-1917, p. 181, in Annette Becker, 1998, p. 86.

${ }^{209}$ Pierre-Maurice Masson, 22 February 1915, in Annette Becker, p. 21. 
nervous release that I cried without knowing why. ${ }^{210}$ He was not ashamed to express his true feelings to his mother. While some French soldiers no doubt wrote about the front line so enthusiastically to not worry the women at home, soldiers like Lemercier did not let the concepts of masculinity dominate his letters; he did not have this urge to represent himself as over-masculinized with no fear of the trenches. Evidently, not all soldiers shared this manly longing for the war front, the opportunity to kill the enemy and the glory associated to this.

The role as the protector furthermore broke down as resentment of civilians grew. As Hanna explains, 'Exposed to the unutterable conditions of trench warfare, soldiers grew ever more resentful that civilians neither shared the experience nor appreciated the sacrifices of frontline duty. ${ }^{211}$ Men struggled to believe that women at home could really comprehend how the war experience affected them physically, mentally and emotionally. In addition to this indifference on the home front, many soldiers felt alienated among the front line troops, where their personal desires played no important part at all; soldiers were encouraged to only consider the greater good. Jennifer D. Keene states that soldiers 'feared they would be forgotten by the outside world and desperately sought contact with the homeland as a means of confirming that they had not been abandoned. ${ }^{212}$

Although French Peasant families sent much of their newly acquired cash to the front to reassure them that they were not forgotten, ${ }^{213}$ French soldiers' writings often reflected on this fear of being abandoned: 'When I see my colleagues reading letters from their parents and friends [,] I can't help crying [.] Have pity on me [,] write to me often [.] I beg of you [,] don't forget me [!] I have nothing else on earth to comfort me but the love and confidence that I have in you.' 214 This fear was evidently not particularly masculine. It is important to note, however, that the desperate overtone of Pireaud's letter was masculine in a different way - he took his role as a private man (who tells his wife the truth and shares his sentiments) more serious than his role as a public man (the man who

${ }^{210}$ Lettres d'un soldat, pp. 16-1,7, in Smith, 2007, p. 48.

${ }^{211}$ Hanna, p. 17

212 Keene and Neiberg, p. 87.

${ }^{213}$ Hanna, p. 20

${ }^{214}$ Pireaud, in Hanna, p. 15 
shows no fear). Pireaud was very authentic in the sense that he is being a husband, rather than a soldier; he can be true to himself, not what the trenches and what propaganda expect him to be.

Although soldiers were encouraged by censors to only optimistically speak of the war in letters to their wives, many were not ashamed to mention a sense of frustration over the course of the war. Pireaud wrote in a letter home: 'I am not happy because no one is happy in war. I miss home and those who are dear to me. I also miss my freedom but in comparing my life to that of all my comrades then in comparison to them I really am happy.' 215 This letter particularly, although optimistic at times, revealed an intense desire for peace and a return home. Another soldier, Henri Fauconnier, wrote to his fiancee Madeline: 'I have something to say to you that is a little unpleasant. You have left me without news and you tell me nothing about what is happening with you $[\ldots]$ in fact you are behaving very badly and now you don't find me very friendly. ${ }^{216}$ This shows that the relationships of some soldiers were truly strained by the separation during the war, because news of the other was rare and this caused speculation on the other person's part whether their love could last.

Only through regular correspondence could this fear and separation anxiety be put at ease, as the concerns and anxieties of the soldiers or that of the women at home, became that of the other. Soldiers also could reassure their wives at home that they will not be forgotten. French soldiers' letters did not always manage to reflect on this fearless attitude of soldiers that was so publicly advocated during the time of war. Many spoke of affection to their wives at home, and made no attempt to try hiding their depression of being separated from them. Pireaud showed his frustration but maintained that he would never forget his wife; not even in the event of death: "Why do you not believe me when I tell you that I adore you [,] that I will love you forever [,] whatever happens [.] that nothing can

\footnotetext{
215 Pireaud, 7 July 1917, in Hanna, p. 176.

${ }^{216}$ Henri Fauconnier, Spring 1915, after silence for weeks, in Martha Hanna, p. 92, 'A Republic of Letters: The Epistolary Tradition in France during World War I', The American Historical Review, Vol. 108, No. 5, December 2003, p. 1355.
} 
deprive you of my love not even death [,] because should I die I will die thinking of you. ${ }^{217}$

While Pireaud's letter showed his affection for his wife, it must be recognised that not all French women were worth protecting in the eyes of the soldiers. There were instances in which French women had sexual relationships with German troops, as well as their own. Initially, French propaganda displayed all of these sexual relations between French women and German troops to be involuntary on the women's parts. Take for example the 1916 propaganda poster Seddución (Fig 4.) in which the French woman is tied to a pole with one of her breasts exposed and the German Officer is relaxed in his seat, smiling and threatening the poor woman. Evidently, 'In the French version [...] the story is tidied up so that heroic French women always resisted barbaric Germans. ${ }^{218}$ Without a doubt, there were various instances in which rape did occur. German troops would have raped French women for a number of reasons, one of which was out of fear: 'As the German army advanced through Belgium atingnd into northern France in August 1914, some of its troops, afraid of being set upon by civilian insurgents, did shoot civilians, take hostages, and rape women. ${ }^{219}$ As part of this idea of protecting their women, the soldiers were strongly encouraged to protect their women's honour and bodies from enemy troops. As was the case for many countries involved in the war, "Rape of "our" women sometimes becomes a dominant metaphor of the danger to the nation from enemy males. ${ }^{, 20}$ Felix Klein stated in 1915: 'For, next to the field of battle where the men they love are slain, what is most horrible for women in war is the idea of falling into the hands of the enemy soldiers; the thought that in the absence of husband, bother or son, the house may be invaded, the home outraged by victorious brutes. ${ }^{221}$

In regards to prostitution specifically, in the eyes if the soldiers these women were not worthy of protection. French soldiers recognised that some of these

${ }^{217}$ Pireaud, 19 May 1915, in Hanna, 2006, p. 74.

218 Deborah Cohen, and Maura O'Connor, (eds.), Comparison and history: Europe in crossnational perspective, New York: Routledge, 2004, p. 76.

${ }^{219}$ Hanna, 2006, p. 122.

${ }^{220}$ Goldstein, p. 369.

${ }^{221}$ Felix Klein, Diary of a French Army Chaplain, Andrew Melrose: London, 1915, pp. 18-19, pp. 24-27, in Marilyn Shevin-Coetzee and Frans Coetzee (eds.), Empires, Soldiers, and Citizens - A World War 1 Sourcebook, Wiley-Blackwell an imprint of John Wiley and Sons Ltd: United Kingdom, 201, p. 14. 
sexual relationships were in fact voluntary. Pireaud, for example, believed that some women were raped but also condemned some French women as unworthy of the sacrifices made on their behalf: "their poor husbands are in the trenches enduring the worst miseries putting their own lives on the line to prevent the Prussians from coming to defile and slit the throats of these women. ${ }^{222}$ It is particularly interesting to see that this 'rape of our women' theory, an idea so popular and utilised by all countries' in the war, was not so easily taken on by the French soldiers. Soldiers clearly distinguished between the women worthy of protection, and those that were not.

Although soldiers appeared particularly eager to disgrace particular women for their sexual behaviour, soldiers were not at all prepared to discuss their own sexual endeavours. The image of the oversexed Frenchman is a well-known one, and the fact that the French army operated the most brothels during the war, may come as no surprise to some. ${ }^{223}$ The French soldiers' sexuality could be seen as normal yet problematic. Due to the new conscription regulations in place during the Great War, a much wider range of men were allowed to enlist than had previously been the case. As Judith Surkis explains: 'In the past, the potentially degrading effects of military life were concentrated and contained by the professional army. With universal conscription, soldiers' demoralization affected (and in the case of venereal disease, infected) the social body as a whole.'224 Established with the help of ligue de l'enseignement "foyers du soldat", reading and game rooms were established as forms of distraction barracks. ${ }^{225}$ In addition, 'Beyond advocating a rigorous policy of surveillance, army doctors regularly reported the names of prostitutes who were purportedly responsible for infecting soldiers to local authorities. ${ }^{226}$ While the spread of venereal disease was to be expected amongst the soldiers of the frontline, engaging in prostitution was still seen as a shameful secrecy that the army officials aimed to minimise. Throughout this research, there have been no letters by French soldiers that mention sexual relations while being away from home. This lack of recognition of prostitution

\footnotetext{
222 Pireaud, 23 March 1915, in Hanna, 2006, p. 122.

${ }^{223}$ Goldstein, p. 344.

224 Judith Surkis, Sexing the Citizen - Morality and Masculinity in France 1870 - 1920, Cornell University Press: Ithaca and London, 2006, p. 213.

225 Ibid. , p. 219.

226 Ibid., p. 215.
} 
and unfaithfulness, demonstrates that soldiers were not proud of such relationships. They protected their families at home from embarrassment and shame by doing so.

\section{German Soldiers on Protection of Women}

The patriarchal family was a national characteristic of Germany and just like what we have seen in France, with the male being the provider and protector. As the roles of the two genders took on some new forms in the time of war, some tensions arose. Officials feared the interaction with the homefront, as it could lower morale at the front and encourage the realisation that men were losing their role at home. ${ }^{227}$ The idea that rivalry between men and women increased is argued by a number of historians because while men fought to protect women, they became an economic rival at home. ${ }^{228}$ Robert L. Nelson builds on this idea and explained that women similarly suffered under the changes made to their traditional roles: 'The new image of German women was brought about by a "total war" economy which forced women to move into strange, previously male occupations, while learning to cope with a poorly organized state system of food rationing, and intensifying their already burdensome household production. ${ }^{229}$

Despite the apparent tensions between the genders, I would argue that certain aspects of their traditional roles were certainly maintained. For example, women were also encouraged to maintain their feminine virtues to support the soldiers emotionally: 'For girls war was the time to show the feminine virtues: selflessness, thriftiness, and steadfast, cheerful support of men and Germany, whatever the hardship. ${ }^{230}$ Particularly mothers were thought of as 'the primary emotional connection for young men, and the embodiment of the family. ${ }^{231}$ It

227 David Welch, Germany, Propaganda and total war 1914 - 1918, Rutgers University Press: New Brunswick and New Jersey, 2000, p. 21.

${ }^{228}$ Birthe Kundrus, 'Gender Wars the First World War and the Construction of Gender Relations in the Weimar Republic', in Karen Hageman and Stefanie Schueller-Springorum (eds.), Home/Front: The Military, War and Gender in twentieth Century Germany, Berg Publishers: Oxford and New York, 2002, p. 164.

${ }^{229}$ Robert L. Nelson, 'German Comrades - Slavic Whores Gender Images in the German Soldier Newspapers of the First World War', in Hageman and Schueller-Springorum, p. 77.

${ }^{230}$ Andrew Donson, Youth in the fatherless land - war pedagogy, nationalism, and authority in Germany, 1914 - 1918, Harvard University Press: Cambridge, Massachusetts and London, 2010, p. 85.

${ }^{231}$ Michael Roper, 'Maternal relations: moral manliness and emotional survival in letters home during the First World War', in Stefan Dudink, Karen Hageman and John Tosh, (eds), 
should come as no surprise that most letters home were sent to mothers. There is little tension in the letters of this study. Indeed, there is very little evidence to suggest that men were truly bothered at all about the reversed gender roles, as the soldiers truly focused on their roles as soldiers and protecting women at home. There are various ways in which German soldiers attempted to do this in their letters.

Some of the techniques we have seen in French soldiers' letters were also used in German soldiers' writings. One of the things that stand in the foreground is the reassurance that soldiers had enough food supplies. This varied in soldiers' letters. Hanns von Einsiedel wrote early in the war: 'I am writing in a very cozy small dining room, where we had pea soup, followed by chicken with rice for lunch. With that we had a 1887 Burgundy, dessert wine, which would have been very precious, but too strong for me. ${ }^{232} \mathrm{He}$ goes on: 'Today I received in this way marmalade and cherry compote, as well as honey and a pot full of lard. So now we can bake pancakes again and also fry something. ${ }^{233}$ Ludwig Sckell similarly wrote in 1916: 'We get good food here; even better than in Weimar. Several times a week we get butter, cheese, marmalade etc., good lunches, every day a third of a bread which is plenty - so there is no famine here. ${ }^{234}$ Such plenty of food no doubt reassured these soldiers' wives that there was no reason to worry and send food to the front.

Additionally, soldiers attempted to highlight the insignificance of death and attempted to prevent women from suffering when a life was lost. Leonard V. Smith writes that despite intense physical labour German women were experiencing on the home front, the constant fear of loved ones dying at the front

Masculinities in Politics and War - gendering modern history, Manchester University Press: Manchester and New York, 2004, p. 301.

232 Rittmeister Hanns to his wife, 5-6 September 1914, in Bechmann and Mestrup, p. 132. 'Ich schreibe in einem kleinen sehr netten Esszimmer, wo wir heute Mittag Huhn mit Reis gegessen haben. Vorher Erbssuppe. Dazu einen Burgunder 1887, Beerenauslese, der wohl äußerst kostbar, mir aber zu heiss ist.'

${ }^{233}$ Ibid, p. 133. 'Heute erhielt ich auf diese Weise Marmelade und Kirschkompott, ebenso Honig und soeben einen Topf mit Schweinefett. Nun können wir wieder Eierkuchen backen und auch mal braten.'

${ }^{234}$ Ludwig Sckell to his parents, 30 June 1916, in Denis Bechmann und Heinz Mestrup, Quellen zur Geschichte Thüringens - Wann wird das Morden ein Ende nehmen? Feldpostbriefe und Tagebucheinträge zum Ersten Weltkrieg, Landeszentrale für politische Bildung Thüringen: Erfurt, 2008, p. 128. 'Wir bekommen hier gutes Essen, besser noch als in W[eimar]. Wöchentlich gibt es verschiedene Male Butter, Käse, Marmelade usw., gute Mittagskost, jeden Tag ein Drittel Brot reichlich ist-also es herrscht keine Not hier.' 
was much more intense: 'There were certain obvious material and physical discomforts, such as long working hours, serious inflation, and shortages of consumer goods. Less obvious but doubtless even more intense was the emotional anguish women had to endure.' 235 There was a clear attempt to describe destruction and killing and death in positive terms. Otto Leipner wrote: 'If I fall now, then I will die happier; since I know what I am dying for. Can you envision this moment? ${ }^{236}$ Leipner looked forward to death and advised his parents that he had a purpose, and this is why he may die. While such an attitude no doubt helped Leipner be brave, it also provided his parents with a sense of closure and happiness knowing that he may die in the act of duty; doing something he willingly gave his life for. Similarly, a fellow soldier wrote to his mother in September 1914: 'My life has been so beautiful that I could not wish that anything in it had been different. And its having been so beautiful was thanks above all to you, my dear, good, best of Mothers. And for all your love, for all that you have done for me, for everything, everything, I want to thank you and thank you.' ${ }^{237}$ Not only did he assure his mother that he has had a joyful, happy life, but he took the extra step to attribute this directly to his mother.

Soldiers also had a specific role of protecting women from sexual attacks from the enemy: 'Onto their shoulders fell the responsibility to actively defend female honor, and to protect girls and women from the sexual attacks of enemy soldiers. ${ }^{238}$ Just like we have seen with French soldiers' letters, there was a trend to distinguish between their own women and that of the enemy. Particularly 'French women were criticized for their lack of morality and loyalty, and their tendency to frivolity and materialism. They were depicted flirting with the German soldiers, showing no desire to wait faithfully for the end of the war and the return of their husbands. ${ }^{239}$ They were considered temporary and convenient

235 Leonard V. Smith, 'Women Readers of Henri Barbusee: The Evidence of letters to the Author', in Pierre Purseigle (ed.), Warfare and Belligerence - Perspectives in First World War Studies, Brill: Leiden and Boston, 2005, p. 347

236 Otto Leipner, Reims-Neufville, 2 October 1914, in Ilse Walter, Feldpost - Briefe aus dem 1. Weltkrieg, www.damals-muesst-ihr-wissed.de, accessed 31/01/2014, p. 2. 'Wenn ich jetzt falle, dann sterbe ich gluecklicher, ich weiss wofuer. Koennt Ihr euch diesen Augenblick vergegenwaertigen?'

237 Anonymous soldier, 24 September 1914, in Philipp Witkop, German Students' War Letters, First Pine Street Books: United States of America, 2002, pp. 17-21.

${ }^{238}$ Nelson, in Hageman and Schueller-Springorum, p. 76.

${ }^{239}$ Ibid., p. 78. 
at the time, but it was reinforced that this was not an opinion to be held of their faithful women waiting at home. Robert L. Nelson explains this in more detail: 'Through her loyalty, a woman protects not only her own honor, but that of her husband as well. He must protect her honor from any and all attacks. If he fails as a protector, he fails as a man. ${ }^{240}$

One important distinction that should be made between French and German soldiers is the fact that German soldiers were not expected to make a secret of their love conquests abroad. Nelson explains: 'While for German women it was understood that female loyalty meant monogamy, this was not expected of either the women of the enemy or of the German soldiers themselves. There was no attempt in the soldier newspapers to disguise the fact that the German men were being sexually "disloyal" to their partners all the time.' 241 Again, those prostitutes who were not registered faced imprisonment for at least one year, or banishment from the occupied districts as part of the codes of moral. ${ }^{242}$ Such punishment was not in place, however, for German men that interacted with these women.

German soldiers' letters frequently referenced the countryside and the homeland's physical beauty in an effort to distract women from the severities of war. Walter Hagen, for example, wrote about the beautiful sight of stars at night time: 'A gorgeous spring night made me stay in the open, after having slept all whole day in the trenches. The stars and the moon shone gloriously in the sky.'243 Celia Applegate explains that the reference to the beautiful countryside could derive from propaganda and literature that spoke of the Heimat: 'This Pfalz was a land of beautiful vistas and peaceful agricultural and industrial scenes. In absolute contrast to the battlefield, wartime literature and art depicted wheat fields and vineyards, rivers and hills, cities and villages infused with the warm sunlight and peaceful mood of Heimat sentiment. ${ }^{244}$

\footnotetext{
${ }^{240}$ Nelson, in Hageman and Schueller-Springorum, p. 80.

${ }^{241}$ Ibid., p. 79.

${ }^{242}$ Marilyn Shevin-Coetzee and Frans Coetzee (eds.), Empires, Soldiers, and Citizens - A World War 1 Sourcebook, Wiley-Blackwell an imprint of John Wiley and Sons Ltd: United Kingdom, 2013, p. 173.

${ }^{243}$ Walter Hagen to his parents in Altenburg, 25 April 1915, in Bechmann and Mestrup, p. 253. 'Eine schöne Frühlingsnacht ließ mich, nachdem ich den ganzen Tag im Graben gepennt hatte, im Freien aufhalten. Herrlich prangten die Sterne am Himmel und der Mond.'

244 Celia Applegate, A nation of Provincials - The German Idea of Heimat, University of California Press: Los Angeles, 1990, p. 116.
} 
Soldiers furthermore compared the distraught scenes on foreign soil and Germany's untouched beauty to assure women that they were being protected from suffering the same fate. As German soldiers invaded other countries, they did not experience the degree of destruction of their own soil as the enemy's soldiers did. This led soldiers to think about how lucky they were for only fighting on foreign soil. They often used phrases such as 'Thank God that our homeland has been protected from the war! The misery of the poor people here burns brighter in the sky than their wooden huts'. ${ }^{245}$ They could compare the beauty of their own land to that of the enemy's, which experienced the force of the war first hand. Karl Probst explains this attitude in more detail by stating: 'Wherever you turn, the land is ransacked; dugouts and communication trenches alternate. It will be years of work before these fields can be farmed again. That is why it is a blessing that we are only standing in enemy territory. What a great pity it would be if our beautiful Heimat would be destroyed like this!'246 Such writing assured the women at home that the soldiers were doing all they could to protect the homeland, as well as making sure that the soldiers did not forget where they came from despite some soldiers having been away from Germany for many years.

A way in which soldiers attempted to steer away from the physical destruction of land was to explain how they attempted to beautify the land, another feature of letter writing which appeared attractive to women. Ludwig Sckell, for example, wrote many detailed letters in 1916 about the gardens he was in charge of in France. He wrote how busy he was maintaining the gardens: 'There is a lot of gardening work to do, planting vegetables, which however is already very late in

${ }^{245}$ Walter Flex to his parents, 2 Septmeber 1915, in Bechmann and Mestrup, p. 108. 'Dankt Gott, daß er unsre Heimat vor dem Kriege bewahrt hat! Das Elend der armen Leute hier brennt heller zum Himmel als ihre Holzhütten.'

${ }^{246}$ Karl Probst to the widow Marie von Schwarzburg-Sondershausen, 18 February 1915, in Bechmann and Mestrup, p. 83. 'Überall, wohin man sieht, ist das Land durchwühlt, Schützengräben und Laufgräben wechseln mit einander ab. Es bedarf jahrelanger Arbeit, ehe die Felder wieder bebaut werden können. Deshalb ist es ein wahrer Segen, daß wir überall in Feindesland stehen. Welch großer Jammer wäre es, wenn unsere schöne Heimat so verwüstet wäre!' 
the year, picking strawberries, weeding, maintaining walkways, changing waste land into a good, useful condition etc etc.' . ${ }^{247}$

All these references to the landscape hint at the longing for home. Walter Flex writes about the Christmas of 1915 in a letter to his parents from June 1916 . He wrote: 'And there is something so infinitely touching, when despite the raging wind under the clouds of snow, from left and right a few tunes of "Silent Night, Holy Night" or "O thou happy, O thou holy" come across. It was as if Christmas strings were carried across from all the trenches to Germany like invisible telephone lines.' 248 Traditional German songs created an atmosphere of home for Flex and his fellow soldiers. German soldiers were not meant to show desperation for an end to the war in an effort to return home faster. They were supposed to endure without complaining. Flex's letter is the perfect example of showing his longing for the homeland in a positive way; he feels connected to the homeland.

The longing for the homeland leads on to the idea of longing for family members back at home as well. The prospect of reunion is a popular theme employed by numerous German soldiers' letters to assure the women at home they were not forgotten. A report on morale in 1917 stated: 'Nothing so cheers and heartens men as the prospect of leave; and, judging by the letters it is impossible to emphasise too strongly the importance of leave as a factor in the moral of the Army... The immediate prospect of leave, as something visible and tangible, seems to count for more to men's minds than the ultimate visionary hope of peace.' ${ }^{249}$ Walter Hagen writes to his mother: 'O how happy I will be when I can hurry back to you, my dear loving mother, and kiss your face and cover it with tears of joy.' He goes on: 'When I come back, I will be a completely

${ }^{247}$ Ludwig Sckell to his parents, 30 June 1916, in Bechmann and Mestrup, p. 128. 'Es gibt in den gärtnerischen Arbeiten viel zu tun, Gemüse anzupflanzen, was allerdings schon sehr spät [ist], Erdbeeren pflücken, jäten, Wege instand halten, raches Land in guten, gebrauchbaren Zustand setzen usw. usw.'

${ }^{248}$ Walter Flex to his parents, 26 December 1915, in Bechmann and Mestrup, p. 153. 'Und es hatte etwas unendlich Rührendes, wenn einem trotzdem der rasende Wind unter Wolken von Schnee bald von rechts, bald von links ein paar Klänge von „Stille Nacht, heilige Nacht“ oder „O, du fröhliche, o du selige“ zutrug. Es war, als ob aus all den Gräben Weihnachtsfäden wie unsichtbare Telephonleitungen im Winde schwängen und nach Deutschland leiteten.'

${ }^{249}$ M. Hardie, IWM, 841/46/1, Report on Morale c.111 Army,1 January 1917, in Alexander Watson, Enduring the Great War - Combat, Morale and Collapse in the German and British Armies 1914-1918, Cambridge University Press: Cambridge, 2008, p. 101. 
different person; then let us lead quite a happy family life.' ${ }^{250}$ Hagen reassured his mother that the life as a soldier has improved his personality and he will be a better man when he returns to her. This is something quite new compared to French soldiers' writings; although the French also reassure their families at home that they miss them and want to reunite with them, they do not attempt to describe the war as an experience that will improve their character.

Rudolf Theis Eden is a little more desperate in his letter to his wife where he writes that the distance between the two heavily weighs on their relationship: 'but it felt to me, as if you were suddenly pushed far far away from me; while you were all mine in the morning, now all the others have taken control over my wife, and now you are not really mine anymore'. ${ }^{251}$ He found it difficult to associate himself with his wife to an extent, but then he compensates for this statement by describing how benefical a reunion between them would be for their relationship: 'How badly, oh just how badly I would love to be with you for just a brief moment, I just want to see you once, look into your lovely eyes, hold your hand, then return back to this condemned place. Everything I do, I do just for you, Yours Theis. ${ }^{252}$ Despite the fact that Eden mentioned a strain on their relationship, they could overcome this and he showed his wife that he still deeply cared for her and his actions at the front were in fact acts of love for her; he fought for her. From this, I would argue that German soldiers in general wrote less about the difficulties of maintaining a relationship from the distance, but instead focused on highlighting the prospect of a happy reunion.

Soldiers also reminded women of happy memories in an effort to protect women from the severity of war. Take for example Rudolf Theis Eden, who wrote: 'Do you still remember this day two years ago? It was a Friday and one of the best days of my life. What a great time it was! That day we played tennis

${ }^{250}$ Walter Hagen to his mother, 21 December 1914, in Bechmann and Mestrup. p.267. 'O wie glücklich werde ich sein, wenn ich wieder an Dein liebend Mutterherz eilen und Dir mit Küssen und Freudentränen das Antlitz bedecken kann. 'He goes on: 'Wenn ich wieder komme, dann bin ich ein ganz anderer Mensch; dann wollen wir ein recht glückliches Familienleben führen.'

${ }^{251}$ Dr. Rudolf Theis Eden to his wife Daniela Eden, 1 January 1915, in Bechmann and Mestrup, p. 211. 'aber es war mir plötzlich, als wenn Du weit, weit von mir abgerückt und fern wärst, wo ich Dich heute morgen noch so ganz hatte; als wenn alle die andern Besitz genommen hätten von meiner Frau und sie nicht mehr so ganz, ganz mein wäre.'

${ }^{252}$ Ibid., 'Wie gern, wie so gern wäre ich jetzt nur einmal schnell bei Dir, nur einmal sehen möchte ich sie, einmal ihre lieben Augen sehen, einmal ihre Hand fassen, dann wieder zurück in diese verdammte Gegend. Nur für Dich ist alles, was er tut, Dein Theis.' 
eagerly and then went home together in the evening. ${ }^{253}$ There was a clear effort to stay away from describing the battlefield and to focus on far-away experiences instead. It appears that even though soldiers were encouraged to be brutal men on the battlefield, their role as protector clearly encouraged them to not extend such stories of brutality to women at home; their role as protector was both brutalized and domesticated.

Men were prompted to become increasingly more brutalized, perhaps as a means to deal with the disturbing images of war. One soldier wrote to his wife about the fear of succumbing to the extremely hardened ideal man:

One thing weighs upon me from day to day - the fear of getting brutalized. Your wishing you could provide me with a bullet-proof net is very sweet of you, but strange to say I have no fear, none at all, of bullets and shells, but only of this great spiritual loneliness. I am afraid of losing my faith in human nature, in myself, in all that is good in the world [...] it is much harder for me to endure the incredibly course tone that prevails among the men here. ${ }^{254}$

He is embarrassed that he paid more attention to his loneliness rather than the sufferings and wounds of the people around him. The fact that he still has this fear, however, precisely showed his wife that he is still very much human; otherwise he would not have had this fear.

Despite all these attempts and hopes to de-brutalize the war experience in letters home, some letters show that the role as protector broke down through particularly gruesome descriptions of the battlefield. French soldiers were less likely to write home about dead bodies and destruction compared to German soldiers. Birthe Kundrus argues that this may be due to the fact that German women were so strongly masculinized in their wartime identity, providing for their families, and doing hard physical labour. ${ }^{255}$ Perhaps women were considered stronger in this regard than French women. Some of the examples of extreme

253 Ibid., 29 August 1915, in Bechmann and Mestrup p. 212. 'Weißt Du noch, wie es heute vor zwei Jahren war? Da war Freitag und einer der schönsten Tage meines Lebens. War das eine schöne Zeit! An diesem Tage haben wir noch eifrig Tennis gespielt und sind dann am Abend zusammen heim gegangen.'

${ }^{254}$ Anonymous soldier, October 14, 1914, in Shevin-Coetzee and Coetzee (eds.), p. 63.

${ }^{255}$ Kundrus, in Hageman and Schueller-Springorum, p. 160. 
violence include Kanonier Kellers, who wrote to his mother: 'The lieutenant, as the platoon leader, was torn apart. Only his legs were found; everything else had disappeared. Iron pieces and bloody human bones flew as far as toward us.'256 Such descriptive writing leaves little to the imagination and does not attempt to beautify the scenes on the battlefield.

German soldiers specifically wrote about the enemies' wounds and dead bodies. Keller, for example, wrote: '[there] lay 60 to 70 Russians, dead or injured, piled on each other. It was a horrific sight. We then still had to pass them with our guns and had to watch the poor guys trying anxiously not to get under the horses or wheels. ${ }^{257}$ Gerhard Theodor Bernhard Goepel's letter showed a particularly gruesome scene of a dead Russian soldier:

His face was already bloated and darkened from the decomposition process, so that you could mistake him for a Negro at night. He was lying on his woollen blanket, with one of his hands he had ripped up his coat, the other hand was stretched up in the air and horribly shrivelled. Indefinite effort and love had been devoted to him for decades, and now he was rotting somewhere in a roadside ditch. $^{258}$

While French soldiers also wrote about dead soldiers, this was done so really only by mention, rather than in more detail. Perhaps German soldiers really were more successful in dealing with seeing their enemies' dead bodies; perhaps propaganda has simply pushed them to be more accepting of corpses. On the other hand, perhaps they realised that writing detailed descriptive letters of enemy corpses would let them cope with the scenes of war better, rather than writing about their fellow comrades' dead bodies.

${ }^{256}$ Keller, to his mother, 21 September 1914, in Bechmann and Mestrup, p. 95. 'Der Leutnant als Zugführer wurde auseinandergerissen. Von ihm fand man nur noch die beiden Beine, alles andere war verschwunden. Bis zu uns hin waren die Eisenteile und blutige menschliche Knochen geflogen.'

${ }^{257}$ Keller, to his mother, 21 September 1914, in Bechmann and Mestrup, p. 96. 'lagen 60 bis 70 Russen tod [sic] oder verwundet auf einen [sic] Haufen. Ein entsetzlicher Anblick. Wir mussten dann noch mit unseren Geschützen darüber hinweg und mussten sehen, wie die armen Kerle ängstlich versuchten, nicht unter die Pferde und Räder zu kommen.'

258 Gerhard Theodor Bernhard Goepel, to his parents, 12 December 1914, in Bechmann and Mestrup, p. 96. 'Sein Gesicht war vom Verwesungsprozeß bereits aufgedunsen und gedunkelt, so daß man ihn bei Nacht für einen Neger halten konnte. Er lag auf seiner Wolldecke, mit der einen Hand hatte er sich den Rock aufgerissen, die andere war verkrampft in die Luft gestreckt und grauenvoll zusammengeschrumpft. Unendliche Mühe und Liebe war[en] jahrzehntelang auf ihn verwandt worden, und nun verweste er irgendwo in einem Straßengraben.' 
German soldiers' role as protector of women and family furthermore broke down through taking on a disinterested stance on being a family man. Particularly after having seen how passionate some of the letters from the French soldiers have been, one cannot help but notice a hardening when similar topics regarding families are discussed by German soldiers. Ludwig Sckell is perhaps more emotional than the general German soldier by writing how desperate he is for his sister and mother to get well after falling ill: 'Now my only wish is that you two patients get well soon. This illness should not be taken lightly, as already many people have died from this malicious sickness. ${ }^{259}$ This shows a similar concern for the women's well-being at home.

In sheer contrast to this, we see examples of how largely disinterested and unaffectionate the German soldier can be. Wilhelm Ernst wrote to his wife in 1915: 'But I simply cannot understand that you, in a way, want to punish me by not wanting a child! Now that officers and men are being furloughed, so that birth numbers do not decline too much. Now it is every woman's duty to care for reproduction. What else is to become of our Volk! ${ }^{260}$ Perhaps this was not a particularly happy marriage, and such writing is very much reliant on what kind of relationship the two have, but it definitely shows that Ernst took his role as a soldier and as a man more serious than his role as a caring family man. Reproduction is very important to him; not so much as he would like a child for himself, which he can see grow up, but rather because he sees it as his manly duty to supply Germany with more children. Compared to French soldiers' letters, there have been fewer examples of German men in their family roles. This is a key difference between the respective countries' soldiers' letters.

\footnotetext{
${ }^{259}$ Ludwig Sckell to his sister Charlotte Sckell, 4 November 1918, in Bechmann and Mestrup, p. 218. 'Mein einziger Wunsch ist nun, daß Ihr beide Patienten baldigst gesunden möget. Die Sache ist nicht leicht zu nehmen mit der Erkrankung, da doch bereits viele Menschen an jener eimtückischen Krankheit gestorben sind.'

${ }^{260}$ Wilhelm Ernst to his wife Feodora, 26 August 1915, in Bechmann and Mestrup, p. 285. 'Aber ich kann wirklich nicht verstehen, daß Du mich gewissermaßen dadurch strafen willst, daß Du kein Kind haben willst! Jetzt werden gerade Offiziere und Leute beurlaubt, damit die Geburten nicht zu sehr zurückgehen. Jetzt hat gerade jede Frau die Pflicht, für die Fortpflanzung zu sorgen. Was soll sonst aus uns[e]rem Volk werden!'
} 


\section{Conclusion}

French propaganda persuaded men to keep fighting by putting them in the role of protector. Although French soldiers used various techniques in their letters to distract women from the brutalities of war, their role as protector could break down due to potential resentment of the civilians, and soldiers recognizing that not all French women were worth protecting. German soldiers also employed a number of techniques to protect their women at home through letter writing, one of the more pronounced techniques being the references to the homeland and countryside. Yet it appears that German soldiers more strongly broke from patterns of protecting women through descriptive letters which reflected on the brutalities of war. German soldiers were more likely to write home about bodies, death and destruction compared to French soldiers. 


\section{Conclusion}

What this thesis has shown is that there truly is a new focus on the historiography of the First World War. Although English historians have started to increasingly use letters as sources to study the war, the use of non-English sources is still very rare. This thesis has contributed to the availability of hundreds of German and French soldiers' letters for English historians that have been translated by other historians and myself.

With their emphasis on honesty and intimacy, letters force us to reconsider civilian-combatant relations. Letters were written to strengthen the relationship between soldiers and their families. I agree with Martha Hanna who suggests that 'Honesty, urged on the soldiers by their families, prompted them not only to describe the most traumatic moments of their life at the front but also to confess their moral weaknesses. ${ }^{261}$ The vast majority of detailed descriptions by particularly the German soldiers speak directly of the horrors of war and the soldiers' responses to this. French soldiers also frequently mentioned their disregard for censors. The extreme experience in the trenches, death, and mutilation shaped these men's writings; not censorship.

Additionally, the letters have shown that it is not just brutality and death that needs to be discussed in order to reflect on the realities of war. The fears and joys soldiers experienced in wartime are just as much a part of the war experience. Even if soldiers did not in great detail describe battlefields, their letters still explored their emotional responses; the letters show the soldiers' coping mechanisms. The ways in which soldiers sometimes avoided describing battlefields, are part of the reality of their personality. There is no universal soldier-each soldier's experience is unique, their spirituality and emotional expressions are distinct to only themselves. I agree with Leonard V. Smith's argument that 'In this sense, historical narrative tells us something about what makes individuals function, and how individuals in turn shape history.'262 Although emotional responses to the horrific scenes experienced during the war are universal, the individual responses specifically are not. They all experienced a

${ }^{261}$ Martha Hanna, 'A Republic of Letters: The Epistolary Tradition in France during World War I', The American Historical Review, Vol. 108, No. 5, December 2003, p. 1350.

262 Leonard V. Smith, The embattled self-French Soldier's Testimony of the Great War, Cornell University Press: Ithaca and London, 2007, p. 7. 
different war; they saw different scenes and had different roles in the war effort. When examining an unrepresentative sample of letters of hundreds of soldiers, we can come to general conclusions, and can assess popular themes across them.

While historians have struggled with the comparative approach between different countries of the war, this thesis has shown that it is possible. Jay Winter and Antoine Prost state: 'It is evident that the national character of Great War historiography is very difficult to overcome. We have many books on nations at war. We do not have a history of the war on a global level. Or more precisely, we have successive visions of the war, which hardly overlap at all. ${ }^{263}$ My purpose was to overcome this obstacle - paying each country the same degree of attention and analysis, highlighting similarities but also pointing out distinctive nationalistic characteristics. Through a comparative study, it is revealed which responses of the soldiers are distinctive to their country of origin and which are shared by soldiers from all countries.

The comparative approach did however have certain limitations. Collections of letters for French soldiers dominantly focus on one soldier at a time, and rarely include a vast number of letters from different soldiers, making it more difficult to discover popular trends in French soldiers' letter writing. More sources were needed to do so. Historiographical work on German soldiers' letters has managed to include numerous letters from different soldiers in whole collections instead, consider for example Denis Bechmann and Heinz Mestrup's 2008 collection that was used extensively throughout this research. At the same time, however, a more extensive collection of just one soldier's letters can be particularly useful to see how the soldiers are changed over the course of the war; to see how perceptions change.

In this particular thesis, this focus has been on masculinity and the way soldiers responded to what was expected of them as men. The first chapter focused on the mobilization of men, and discussed the different ways German and French soldiers were encouraged to enlist through patriotism, images of the enemy and religion. The soldiers demonstrate their very patriotic and brave masculine identity through their willing enlistment to war. Goals of personal

263 Jay Winter and Antoine Prost, The Great War in History - Debates and Controversies, 1914 to the Present, Cambridge University Press: Cambridge, 2005, p. 199. 
survival and the defence of the country played a key role for both French and German soldiers, yet the specific ways soldiers chose to response to the challenges of war and maintaining their masculine identity, can vary. Both French and German soldiers took their roles as soldiers seriously. Unlike what has been argued by past historians, soldiers were very much aware of their expendability and were not at all convinced of their invincibility. The vast numbers of letters from both French and German soldiers that aim to reassure their family members that they had lived a happy life, in combination with good-bye letters, reveal this acceptance.

German soldiers' letters found in Philipp Witkop's German Students' War Letters, openly explained to their family members at home that they only joined the war effort out of duty and love for the country, rather than love for war itself. German soldiers also frequently discussed military might of their enemy - while propaganda such as war literature encouraged them to think of the enemy as inhumane, German soldiers evidently saw their opponents as men simply doing their duty as soldiers.

The letters from Pierre Teilhard de Chardin and Hendrik de Man demonstrate that religion was clearly linked to French patriotism and challenge the suggestion among historians that most men turned to God and religion for comfort in war. While it is generally much more likely to hear about women challenging their gender roles, the letters reveal how soldiers sometimes protested against the role they were supposed to have. French soldiers particularly were very vocal about losing their humanity and expressed their disgust at censors and incompetent military leaders. Consider for example the letters from Henri Fauconnier and Pierre Pireaud that contribute to these debates.

The second chapter focused on fraternity and the ways French and German soldiers managed to overcome certain barriers to form close bonds. There were tensions between ideas of fraternity and the hierarchy of the army. Particularly the German army had to work hard to overcome the traditionally aristocratic nature of the officer class and adopt a new, more universal image of military manhood to include men of different backgrounds. 
German soldiers' letters focused on describing heroic acts of others and stories of trying to save comrades to show the meaning of fraternity within the German army. Anton Holzman and Walter Hagen wrote about this as well as about the importance of honouring fellow soldiers in death by visiting gravesides and making sure that these gravesides are decorated accordingly to the soldiers' Heldentod.

The concept of a noble death managed to equalize younger men to older men in the French army. French soldiers focused on a small group identity though, rather than a larger group identity of the whole army. For example, De Chardin's letters demonstrate that although certain class and regional differences of soldiers sometimes posed issues, fraternity within the army was vital to maintain his role as a priest.

The third chapter discussed masculinity in terms of protecting women. Soldiers' letters break down the idea of a joyful war full of opportunity and although many did express a particularly patriotic overtone in their letters, soldiers tended to take their role as provider and protector of the family more seriously than that of the hyper-masculinized soldier who killed with pleasure. Men did not abandon their role in civilian life and prevailed over the challenges they faced at the front. Perhaps a little therapeutic, the letters sent home seemed to help soldiers deal with their experiences and remind them of why they willingly went to war.

A major driving force for all soldiers was the dedication to family and the knowledge that they were protecting their women by going to war. As the letters found in the thesis' third chapter have revealed, there are various techniques utilised by both French and German soldiers to do so. French soldiers, such as De Chardin, used humorous concepts, a lack of brutal descriptions of war wounds and corpses, in combination with a very caring overtone when discussing fatherhood to distract women at home from certain aspects of the war. While Etienne Derville's letter touches on war wounds, the letter was still relatively undescriptive.

German soldiers, alternatively, more frequently included references to landscapes and Germany's beauty and prospects of reunion with family members 
to protect women at home. Evidently, however, German soldiers were much more prepared to discuss violent scenes and stoic attitudes to fatherhood in comparison to French soldiers as the letters from Gerhard Theodor Bernhard Goepel and Wilhelm Ernst have shown. 


\section{Illustrations}

Figure1: 'L' Insomnie du Kaiser', Image from La Grande Guerre par les Artistes, Ref WRA 19.6, Cambridge University Library (from First World War: Personal Experiences database)

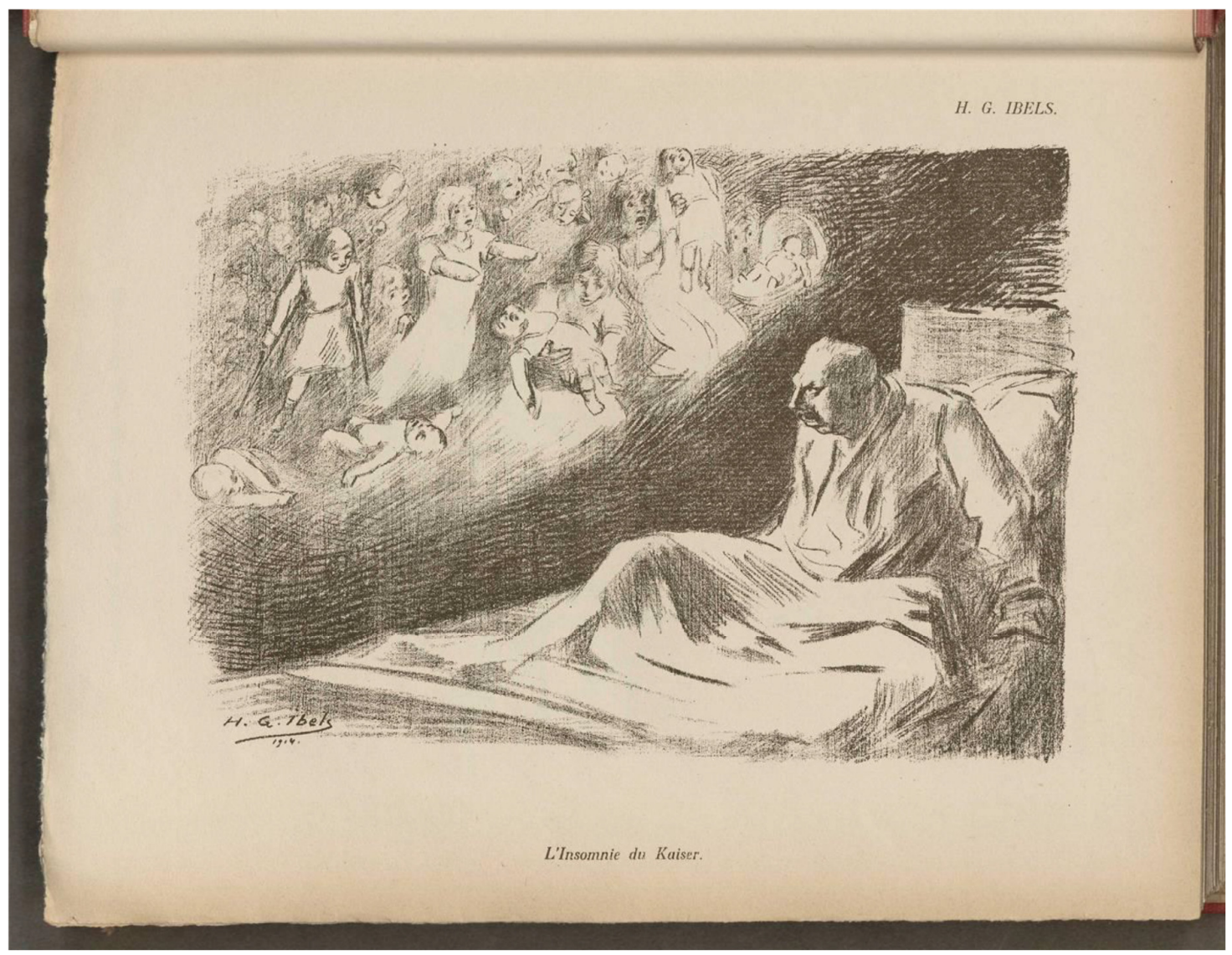


Figure 2: 'Aux armes, citoyens! Formez vos bataillons!', Image from La Grande Guerre par les Artistes, Ref WRA 19.6, Cambridge University Library (from First World War: Personal Experiences database)

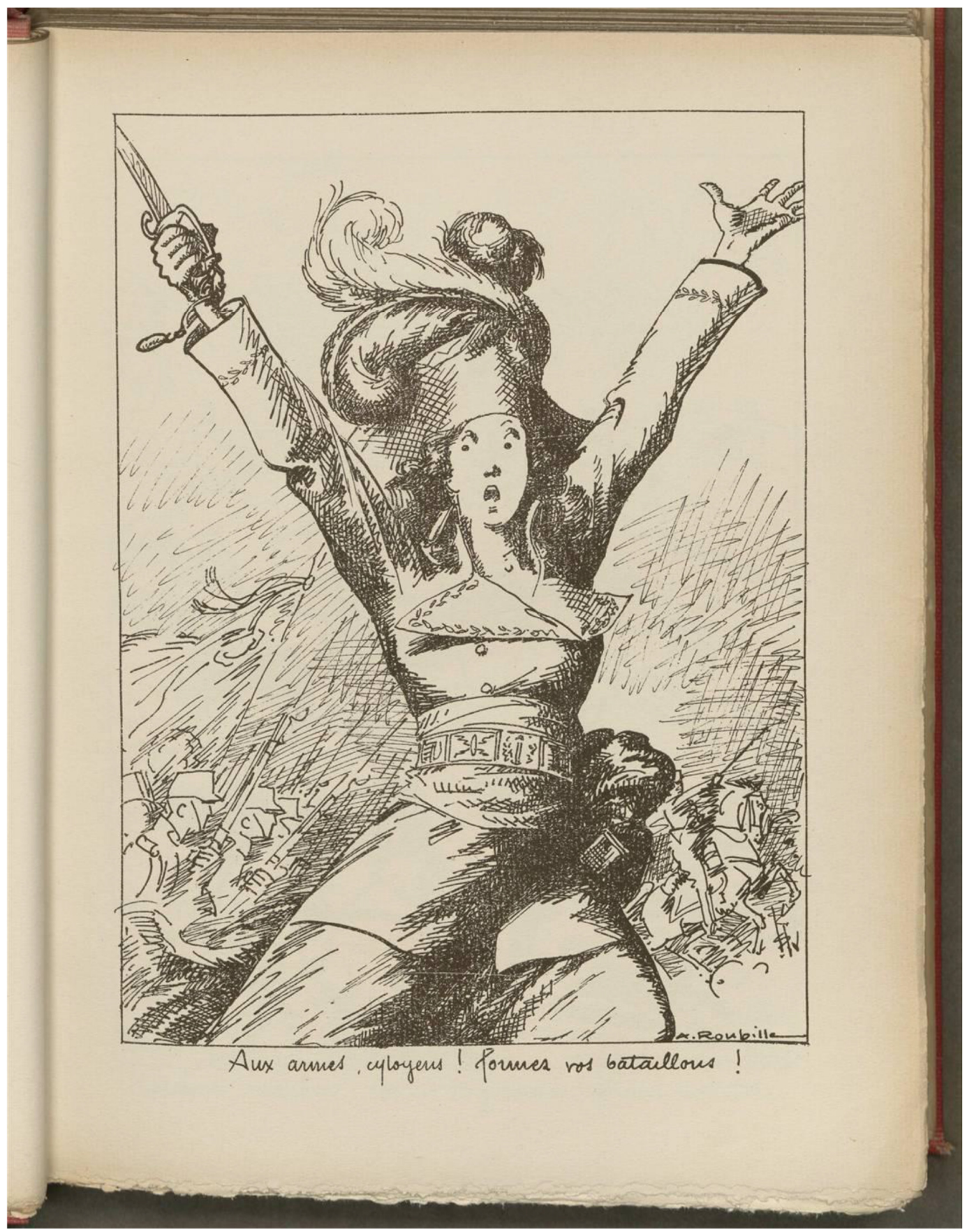


Figure 3: 'Allons, enfants de la patrie. Le jour de gloire est arrive!', Image from La Grande Guerre par les Artistes, Ref WRA 19.6, Cambridge University Library (from First World War: Personal Experiences database)

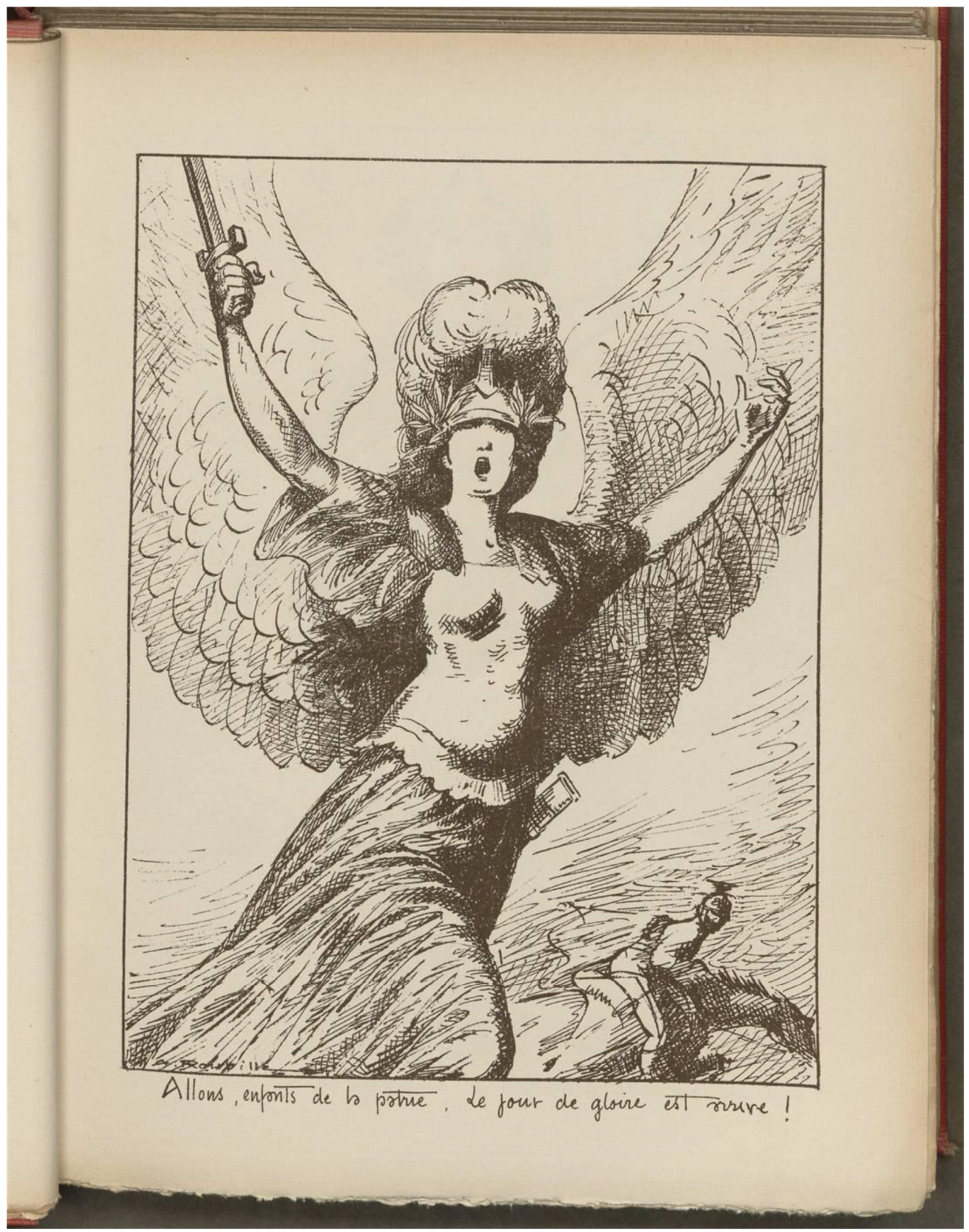


Figure 4: 'Seddución', 1916, Image from Cartones de Raemaekers, Ref WRB 19.317, Cambridge University Library (from First World War: Personal Experiences database)

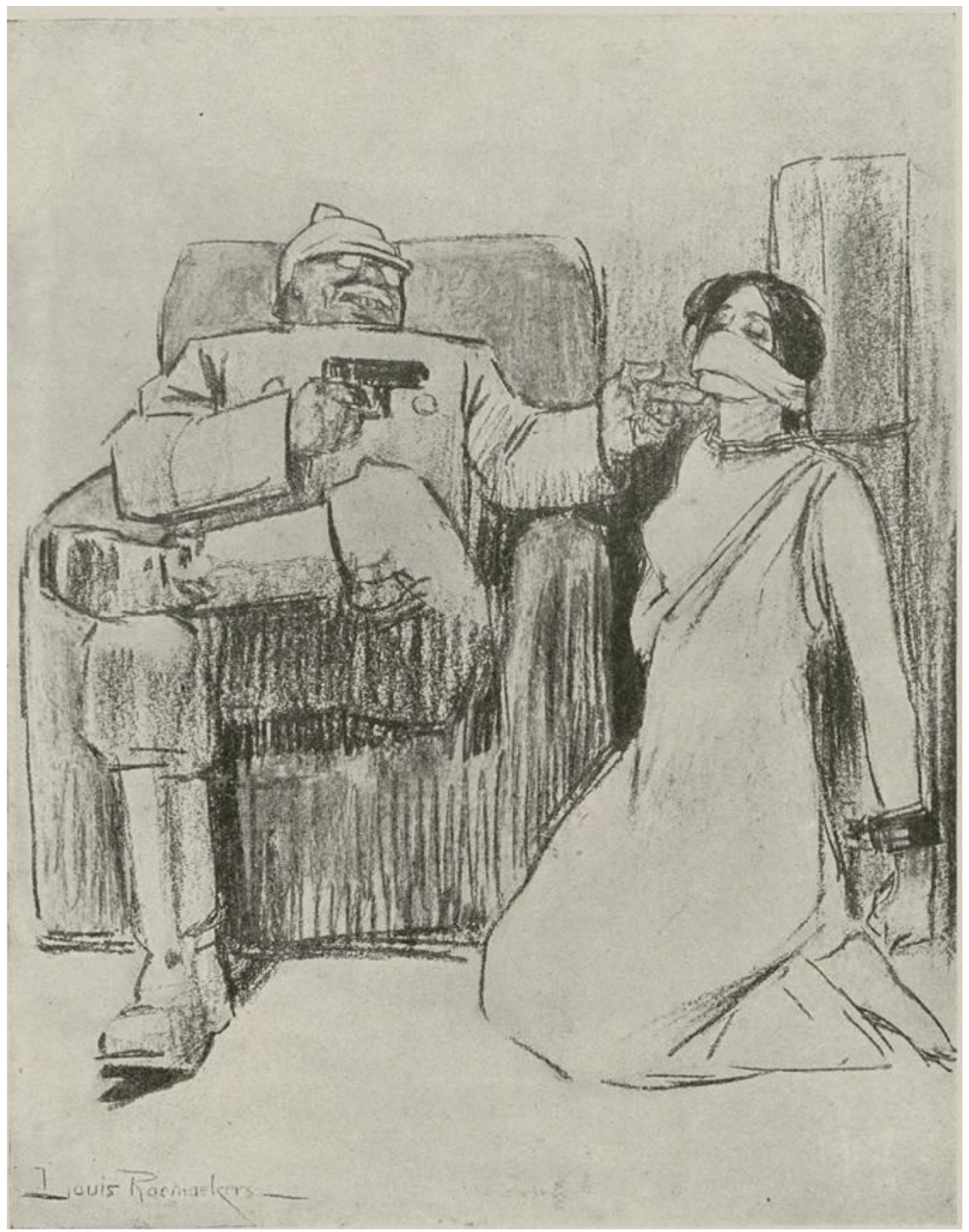




\section{$\underline{\text { Bibliography }}$}

\section{Primary Sources}

\section{Books:}

Derville, Etienne, Correspondence et notes, J. Duvivier: Tourcoing, 1921.

Barbusse, Henri, Lettres de Henri Barbusse à sa femme, 1914-1917, Ernest Flammarion éditeur, 1937.

Bechmann, Denis and Heinz Mestrup, Quellen zur Geschichte Thüringens - Wann wird das Morden ein Ende nehmen? Feldpostbriefe und Tagebucheinträge zum Ersten Weltkrieg, Landeszentrale für politische Bildung Thüringen: Erfurt, 2008.

Boasson, Marc, Au soir d'un monde - Lettres de guerres (16 avril 1915 - 27 avril 1918), Pion: Paris, 1926, letter of 10 July 1916.

Caillaux, Joseph, Mes Memoirs, 3 vol., Plon: Paris, 1942-1947.

Chatenay, Victor, Mon journal de 14-18, Angers, 1968.

Colin, Commandant Jean, Les Transformations de la guerre, Paris, 1911.

De Chardin, Pierre Teilhard, Rene Hague (trans), The Making of a mind - letters from a soldier-priest 1914-1919, London: Collins, St. James’s Place, 1965.

Debeney, general, La Guerre et les Hommes, Reflexions d'apres guerre, Paris, 1937.

Fauconnier, Henri, Lettres à Madeleine 1914-1919, Stock, 1998.

Genevoix, Maurice in 1915, Les Eparges (1923), Ceux de 14 (1949), Flammarion, 1990.

Hageman, Karen and Stefanie Schueller-Springorum (eds.), Home/Front: The Military, War and Gender in twentieth Century Germany, Berg Publishers: Oxford and New York, 2002.

Hanna, Martha, Your Death Would Be Mine; Paul and Marie Pireaud in the Great War, Cambridge and London: Harvard University Press, 2006. 
Léger, Fernand, A War Correspondence, Les Cahiers du Musée national d'art moderne, Occasional / archives, 1997.

Loxley, Simon, Type: the secret history of letters, I.B. Tauris: London, 2004.

Marc, Franz, Lettres du front 1920, Fourbis, sh, 1996.

Mumby, Frank Arthur, Letters of literary men: the nineteenth century, London:

Routledge, 1911.

Nickisch, Reinhard M.G., Brief, Stuttgart: Metzler, c. 1991.

Saintsbury, George, A letter book - selected with an introduction on the history and art of letter-writing, London: Bell, 1922.

Ulrich, Bernd, and Benjamin Zieman (eds.), Christine Brocks (trans.), German

Soldiers in the Great War - Letters and Eyewitness Accounts, Pen and Sword Military: South Yorkshire, 2010.

Walter, Ilse, Feldpost - Briefe aus dem 1. Weltkrieg, www.damals-muesst-ihrwissed.de, accessed 31/01/2014.

Witkop, Phillipp, German Students' War Letters, First Pine Street Books: United States of America, 2002.

Wragg, Harriet, Letters written in war time (XV-XIX centuries), London: H. Milfourd, O.U.P, 1915.

\section{Databases and Websites:}

First World War: Personal Experiences database

Soldatenbriefe aus dem Ersten Weltkrieg, www.g-geschichte.de, accessed 15 January 2014.

The letters of Emilie Sibaud, http://lettresoubliees1418.fr/wordpress/, accessed 22 February 2014.

The letters of Marcelin Cailleau, http://blanchetbr.cc-parthenay.fr/, accessed 20 January 2014 


\section{Secondary Sources}

\section{Books:}

Abrams, Lynn and Elizabeth Harvey (eds.), Gender Relations in German History - power, agency and experience from the 16th to the 20th century, UCL Press: London, 1996.

Amourex, Henri, Petain avant Vichy: la guerre at l'amour, A. Fayard: Paris, 1967.

Applegate, Celia, A nation of Provincials - The German Idea of Heimat, University of California Press: Los Angeles, 1990.

Asprey, Robert B., The First Battle of the Marne, J. B. Lippincourt: Philadelphia, 1962.

Audoin-Rouzeau, Stephane, Men at War 1914-1918: National Sentiment and Trench Journalism during the First World War, Berg, Providence, 1992.

Barton, David and Nigel Hall (eds.), Letter writing as a social practice, Philadelphia: John Benjamins, 1999.

Baron, S. W., The contemporary relevance of history: a study in approaches and methods, New York: Columbia University Press, 1986.

Becker, Annette, Oublies de la grande guerre; humanitaire et culture de guerre 1914-1918, populations occupies, deportes civils, prisonniers de guerre, Ed. Noesis: Paris, 1998.

Becker, Annette, War and Faith - The Religious Imagination in France, 1914 1930, Berg: Oxford and New York, 1998.

Becker, Jean-Jacques, The Great War and the French People, Leamington Spa: Oxford, 1985.

Beckett, Ian F. W. (ed.), 1917: Beyond the Western Front, Konviklijke Brill N. V.: Leiden, the Netherlands, 2009.

Burgwyn, H. James, The Legend of the Mutilated Victory: Italy, the Great War, and the Paris Peace Conference, 1915-1919, Greenwood: Westport, CT, 1993. 
Bland, Caroline and Máire Cross (eds.), Gender and politics in the age of letter writing, 1750 - 2000, Aldershot, Hants, England ; Burlington, VT: Ashgate, 2003.

Blouen, Sarah, Marion Demossier and Jeanine Picard (eds.), Recollections of France - Memories, Identities and Heritage in Contemporary France, Bergham Books: New York and Oxford, 2000.

Bostridge, Mark, Vera Brittain: A Testament to War and Peace, access through The First World War: Personal Experiences database.

Challner, Richard, The French Theory of the Nation in Arms, 1866-1939, New York, 1952.

Cobb, Richard, French and Germans, Germans and French: A personal Interpretation of France under Two Occupations, 1914-1918/1940-1944, University Press of New England: Hanover, 1983.

Cohen, Deborah and Maura O'Connor, (eds.), Comparison and history: Europe in cross-national perspective, New York: Routledge, 2004.

Cultural and Intellectual History Society, European ego-histories: historiography and the self, 1970 - 2000, Athens: Nefeli Publishers, 2001.

Das, Santanu (ed.), Race, empire and First World War writing, Cambridge University Press: Cambridge and New York, 2011.

Donson, Andrew, Youth in the fatherless land - war pedagogy, nationalism, and authority in Germany, 1914-1918, Harvard University Press: Cambridge, Massachusetts and London, 2010.

Dudink, Stefan, and Karen Hagemann and John Tosh, Masculinities in politics and war-gendering modern history, Manchester University Press: UK, 2004.

Frantzen, Allen J., Bloody Good: chivalry, sacrifice, and the Great War, Chicago: University of Chicago Press, c2004.

Goldstein, Joshua S., War and Gender, Cambridge University Press: Cambridge, 2001.

Green, Anna, Cultural history, Basingstoke: Palgrave Macmillan, 2008. 
Hamilton, Richard F., and Holger H. Herwig (eds.), The Origins of World War 1, Cambridge University Press: Cambridge, 2003.

Higham, Robin, and Dennis E. Showalter (eds.), Researching World War $1-A$ Handbook, Greenwood Press: Westport, Connecticut and London, 2003.

Iggers, Georg G., Geschichtswissenschaft im 20. Jahrhundert, Hanover: Wesleyan University Press, 1997.

Iggers, Georg G., New directions in European historiography, Middletown: Wesleyan University Press, 1975.

Jalland, Pat, Death in the Victorian Family, Oxford University Press: New York, 1996, pp. 358-381, 438-441.

Kelly, Jean, Love Letters from the front, Marino Books: Dublin, 2000.

Keene, Jennifer D., and Michael S. Neiberg (eds.), Finding Common GroundNew Directions in First World War Studies, Leiden and Boston: Koninklijke Brill NV, 2011.

Le Goff, Jacques, Pierre Nora and Colin Lucas, Constructing the past: essays in historical methodology, Cambridge University Press: New York, 1985, c1984.

Lengel, Edward G., World War 1 Memories - An Annotated Bibliography of Personal Accounts Published in English since 1919, The Scarecrow Press Inc.: Lonham Maryland, 2004.

Leys, Ruth, Trauma: a genealogy, University of Chicago Press: Chicago, 2000.

Meade, Teresa A., and Merry E. Wiesmer-Hanks (eds.), A comparison to Gender History, Blackwell publishing: Oxford, 2004.

Meyer, Jessica, Men of War: Masculinity and the First World War in Britain, Palgrave Macmillan: London; New York, 2009.

Mickisch, Reinhard M. G., Brief, Verlag J. B. Metzersche Verlagsbuchhanldung: Stuttgart, 1991.

Neiberg, Michael S., Fighting the Great War - a Global History, Harvard University Press: Cambridge, 2005. 
Nye, Robert, Masculinity and Male Codes of Honor in Modern France, Oxford University Press: USA, 1993.

Palmer, Svetlana and Sarah Wallis, A war in words, Simon \& Schuster: London, 2003.

Purseigle, Pierre (ed), Warfare and Belligerence - Perspectives in First World War Studies, Brill: Leiden and Boston, 2005.

Regine, Robin, Histoire et linguistique, Paris: A. Colin, 1973.

Rigney, Anne, Imperfect Histories - The Elusive Past and the Legacy of Romantic Historicism, Cromwell University Press: Ithaca and London, 2001.

Rosinski, Herbert, The German Army, Pall Mall Press: London, 1966.

Schoellgen, Gregor (ed.), Escape into war? The Foreign Policy of Imperial Germany, Oxford: Berg Publishers Limited, 1990.

Shevin-Coetzee, Marilyn, and Frans Coetzee (eds.), Empires, Soldiers, and Citizens - A World War 1 Sourcebook, Wiley-Blackwell an imprint of John Wiley and Sons Ltd: United Kingdom, 2013.

Smith, Leonard V., and Stephane Audoin-Rouzeau, and Annette Becker, France and the Great War 1914 - 1918 - new approaches to European history, Cambridge University Press: United Kingdom, 2003.

Smith, Leonard V., The embattled self-French Soldier's Testimony of the Great War, Cornell University Press: Ithaca and London, 2007.

Surkis, Judith, Sexing the Citizen - Morality and Masculinity in France 1870 1920, Cornell University Press: Ithaca and London, 2006.

Watson, Alexander, Enduring the Great War-Combat, Morale and Collapse in the German and British Armies 1914 - 1918, Cambridge University Press: Cambridge, 2008.

Welch, David, Germany, Propaganda and Total War 1914-1918, Rutgers University Press: New Brunswick and New Jersey, 2000. 
Winter, Jay, and Antoine Prost, The Great War in History - Debates and Controversies, 1914 to the Present, Cambridge University Press: Cambridge, 2005.

Winter, Jay, Remembering war: the Great War between memory and history in the twentieth century, Yale University Press: New Haven, c2006.

\section{Articles:}

Appelt, E. P., 'Vom Wesen der Deutschen Soldatensprache', The Journal of English and Germanic Philology, Vol. 37, No. 3 (Jul., 1938), pp. 367-381.

Chan, Steve, 'Income Distribution and War Trauma: A Cross-National Analysis', The Western Political Quarterly, Vol. 42, No. 3, September 1989, pp. 263-281.

Elkin, Frederick, 'The Soldier's Language', American Journal of Sociology, Vol. 51, No. 5, Human Behavior in Military Society (Mar., 1946), pp. 414-422.

Esdale, Logan, Gertrude Stein, 'Laura Riding and the Space of Letters', Journal of Modern Literature, Vol. 29, No. 4, Summer 2006, pp. 99-123.

Eyerman, Ron, 'The Past in the Present: Culture and the Transmission of Memory', Acta Sociologica, Vol. 47, No. 2, June 2004, pp. 159-169.

Farish, Matthew, 'Modern Witnesses: Foreign Correspondents, Geopolitical Vision, and the First World War', Transactions of the Institute of British Geographers, New Series, Vol. 26, No. 3, 2001,pp. 273-287.

Gere, Anne Ruggles, 'Revealing Silence: Rethinking Personal Writing', College Composition and Communication, Vol. 53, No. 2, December, 2001, pp. 203- 223.

Giesbrecht, Sabine, 'Volksliedarchiv Deutsche Liedpostkarten als Propagandamedium im Ersten Weltkrieg', Lied und populäre Kultur, 50./51. Jahrg., 2005-2006, pp. 55-97.

Gump, Margaret, 'Ernst Penzoldt: Ein Humanist unserer Zeit', The German Quarterly, Vol. 39, No. 1, January 1966, pp. 42-54.

Hanna, Martha, 'A Republic of Letters: The Epistolary Tradition in France during World War I', The American Historical Review, Vol. 108, No. 5, December 2003, pp. 1338-1361. 
Horne, John, 'Entre expérience et mémoire: les soldats français de la Grande Guerre', Annales. Histoire, Sciences Sociales, 60e Année, No. 5 (Sep. - Oct., 2005), pp. 903-919.

Hunter, Kate, 'Sleep on dear Ernie, your battles are o'er: A Glimpse of a Mourning Community, Invercargill, New Zealand, 1914-1925', War in History, 2007, pp. 36-62.

Hunter, Kate, 'Diaries and Letters as Testimonies of War, Introductory essay for World War One: A Portal Module One: The Personal War', Adam Matthew Digital Publications, London, forthcoming 2011, access through The First World War: Personal Experiences database.

Jarka, Horst, 'Soldatenbriefe des ersten Weltkrieges und nationale Bildungsideologie', Monatshefte, Vol. 67, No. 2, 1975, pp. 157-166.

Koopman, Cheryl, 'Political Psychology as a Lens for Viewing Traumatic Events', Political Psychology, Vol. 18, No. 4, December 199, pp. 831-847.

Laqueur, Thomas, 'Memory and Naming in the Great War' in John R. Gillis, ed., Commemorations: The Politics of National Identity, Princeton University Press: Princeton, 1994, pp. 150-167.

Lorenz, Chris, 'Comparative Historiography: Problems and Perspectives', History and Theory, Vol. 38, No. 1, February 1999, pp. 25-39.

Maier, Hans, Ideen von 1914 - Ideen von 1939? Zweierlei Kriegsanfänge, Vierteljahrshefte für Zeitgeschichte, 38. Jahrg., 4. H., October 1990, pp. 525-542. McCallum, Bradley and Jacqueline Tarry, 'Silence', Art Journal, Vol. 62, No. 1, Spring 2003, pp. 82-95.

Michl, Susanne and Jan Plamper, 'Soldatische Angst im Ersten Weltkrieg. Die Karriere eines Gefühls in der KriegspsychiatrieDeutschlands, Frankreichs und Russlands', Geschichte und Gesellschaft, 35. Jahrg., H. 2, Geschichte der Gefühle , April to June, 2009.

Summerfield, Derek, 'Raising The Dead: War, Reparation, And The Politics Of Memory', British Medical Journal, Vol. 311, No. 7003, August 19 1995, pp. 495497. 
Stadelmann, Rudolf, 'Friedensversuche im ersten Jahre des Weltkriegs', Historische Zeitschrift, Bd. 156, H. 3 (1937), pp. 485-545.

Théofilakis, Fabien, 'La sexualité du prisonnier de guerre: Allemands et Français en captivité (1914-1918, 1940-1948)', Revue d'histoire, No. 99, 2008, pp. 203219.

Thiemeyer, Thomas, 'Zwischen Helden, Tätern und Opfern. Welchen Sinn deutsche, französische und englische Museen heute in den beiden Weltkriegen sehen', Geschichte und Gesellschaft, 36. Jahrg., H. 3, 2010, pp. 462-491.

Trevisan, Carine, 'Lettres de guerre', Revue d'Histoire littéraire de la France, 103e Année, No. 2 (Apr. - Jun., 2003), pp. 331-341.

Zechlin, Egmont, 'Ludendorff im Jahre 1915. Unveröffentlichte Briefe', Historische Zeitschrift, Bd. 211, H. 2, 1970, pp. 316-353.

\section{Databases and Websites:}

Anonymous, 'Conscription in France', December 2013, http://en.wikipedia.org/wiki/Conscription_in_France\#World_War_I, accessed $31 / 07 / 14$.

Vance, Jonathan F., Citizen-Soldiers of the Empire: The Dominion Experience in the First World War, access through The First World War: Personal Experiences database.

Watson, Alexander, 'Recruitment: conscripts and volunteers during World War One', $\quad$ http://www.bl.uk/world-war-one/articles/recruitment-conscripts-andvolunteers.

Winter, Jay, A Century of Historical Writing, access through The First World War: Personal Experiences database. 